ALEXANDRE BETINI

\title{
O TRANCAMENTO DO INQUÉRITO POLICIAL
}

\author{
Dissertação de Mestrado \\ Orientação: Professor Doutor José Raul Gavião de Almeida
}

Faculdade de Direito da Universidade de São Paulo

São Paulo

2012 


\section{O TRANCAMENTO DO INQUÉRITO POLICIAL}

Dissertação apresentada à banca examinadora da Faculdade de Direito da Universidade de São Paulo, como exigência parcial para obtenção do título de Mestre em Direito (Direito Processual), sob orientação do professor doutor José Raul Gavião de Almeida. 
Banca Examinadora 
À minha esposa Erika, companheira de todas as horas.

Aos meus filhos Beatriz e Fernando, pelo tempo que os privei de meu convívio. 
Agradecimento especial ao Professor Doutor José Raul Gavião de Almeida, meu orientador, pela confiança, respeito e paciência. 


\section{RESUMO}

O presente estudo aborda o trancamento do inquérito policial.

A proposta de pesquisa é partir da análise de pontos relevantes do inquérito policial, fundamental para a compreensão do assunto tratado, seguindo-se com a análise da justa causa para o início e continuidade da investigação e procurando indicar as causas que podem acarretar seu encerramento antes do momento habitual que é o término das investigações pela autoridade policial.

Além disso, o estudo procura indicar os meios adequados para o trancamento do inquérito, a competência dos órgãos jurisdicionais para a apreciação do pedido e os respectivos recursos.

A forma de apresentação do texto tem por fim facilitar a leitura ao separar os diversos pontos estudados de acordo com o material pesquisado e com o desenvolvimento do raciocínio.

Desenvolvido o tema e alcançadas as conclusões com base nas fontes bibliográficas indicadas e que auxiliam o desenvolvimento dos aspectos mais relevantes, foi possível alcançar o objetivo proposto ao serem apontados os fundamentos que sustentam as opiniões defendidas no decorrer do estudo. 


\section{RIASSUNTO}

Il presente studio affronta la chiusura delle indagini di polizia.

La proposta di ricerca si basa su un'analisi dei punti rilevanti delle indagini di polizia, fondamentali pel la comprensione della materia, seguita dall'analisi della causa per l'avvio e la prosecuzione della ricerca e cercando di indicare le cause che possono portare alla sua chiusura prima alla solita ora, che è il completamento delle indagini da parte della polizia.

Inoltre, lo studio cerca di dimostrari i mezzi appropriati per bloccare l'inchiesta, la competenza degli organi giurisdizionali di esaminare la domanda e le sue risorse.

Il formato del testo è destinato a facilitare la lettura separando i vari punti studiati in funzione del materiale di ricerca e lo sviluppo del ragionamento.

Sviluppato il tema e le conclusione raggiunte in base alle fonti bibliografiche indicate e che aiutano lo sviluppo di aspetti rilevanti, è stato possibile raggiungere l'obiettivo proposto da nominare le basi che sostengono le opinioni espresse durante lo studio. 



\section{SUMÁRIO}

INTRODUÇÃO, 1

\section{O TRANCAMENTO DO INQUÉRITO POLICIAL, 3}

1.1 Considerações iniciais, 3

1.2 Origem e conceito de inquérito policial, 11

1.3 Objeto e finalidade do inquérito policial, 13

1.4 Competência e trancamento, 15

1.5 Investigações pelo ministério público e trancamento, 16

1.6 Investigações das comissões parlamentares de inquérito e trancamento, 20

1.7 Indiciamento e trancamento, 23

1.8 Início do inquérito policial, 25

1.8.1 Crimes de ação penal pública incondicionada, 25

1.8.2 Crimes de ação penal pública condicionada, 32

1.8.3 Crimes de ação penal privada, 33

1.9 Conclusão do inquérito, 34

1.10 Relatório, 36

1.11 Situações do inquérito ao ser encaminhado a juízo, 37

1.12 Diferença entre arquivamento e trancamento do inquérito policial, 40

1.13 Arquivamento implícito do inquérito, 46

1.14 Desarquivamento do inquérito, 47

1.15 Justa causa para instauração e prosseguimento do inquérito policial, 49

1.16 Correlação entre justa causa para o inquérito policial e para a ação penal, 54

1.16.1 Sistema norte-americano, 55

1.16.2 Sistema italiano, 57

1.16.3 Sistema francês, 60

1.16.4 Sistema português, 63

1.16.5 Sistema espanhol, 68

1.16.6 Sistema inglês, 69

1.16.7 Sistema alemão, 72

1.16.8 Sistema belga, 74

1.16.9 Sistema argentino, 76

1.16.10 Código de processo penal modelo para ibero-américa, 77

1.16.11 Sistema brasileiro, 78

1.17 Causas que fundamentam o trancamento do inquérito policial, 81

1.17.1 Inexistência do fato, 82 
1.17.2 Fato atípico, 82

1.17.3 Investigado que não é o autor do fato, 84

1.17.4 Crime impossível, 85

1.17.5 Crime putativo, 85

1.18 Causas de exclusão da antijuridicidade, 86

1.18.1 Estado de necessidade, 89

1.18.2 Legítima defesa, 90

1.18.3 Exercício regular de direito, 91

1.18.4 Estrito cumprimento do dever legal, 92

1.19 Causas de exclusão da culpabilidade, 92

1.19.1 Inimputabilidade, 93

1.19.2 Inconsciência da ilicitude, 95

1.19.3 Inexigibilidade de conduta diversa, 97

1.20 Causas de extinção da punibilidade, 99

1.20.1 Morte do agente, 100

1.20.2 Anistia, 102

1.20.3 Retroatividade de lei que não considera mais a conduta como criminosa, 103

1.20.4 Prescrição, 105

1.20.5 Ausência de representação nos crimes de ação penal condicionada, 106

1.20.6 Ausência de requerimento do ofendido ou de seu rep. nos crimes de ação privada, 106

1.20.7 Decadência, 107

1.20.8 Renúncia, 108

1.20.9 Retratação do agente, 110

1.20.10 Cumprimento da pena no estrangeiro e ressarcimento do dano no peculato culposo, 113

1.21 Trancamento em decorrência da obtenção das provas por meios ilícitos, 114

1.22 Trancamento por aplicação do princípio da insignificância ou da bagatela, 119

1.23 Trancamento por não observância do princípio da duração razoável do processo, 123

1.24 Natureza jurídica da decisão de trancamento do inquérito policial e efeitos, 136

1.25 O PLS 156/2009 e o juiz de garantias, 140

$1.26 \mathrm{O}$ juiz de garantias e o trancamento do inquérito policial, 142

\section{INSTRUMENTOS ADEQUADOS PARA O TRANCAMENTO DO INQUÉRITO POLICIAL, 145}

\subsection{Habeas Corpus, 145}

2.1.1 Origem e considerações iniciais, 145

2.1.2 Natureza jurídica, 147

2.1.3 Espécies, 150

2.1.4 Sujeitos, 151

2.1.5 Cabimento, 152

2.1.6 Requisitos da petição de habeas corpus, 155 
2.1.7 Procedimento, 156

2.1.8 Autoridade coatora para fins de ajuizamento de habeas corpus e competência, 161

2.1.8.1 Autoridade policial como coatora, 161

2.1.8.2 Juiz como autoridade coatora, 163

2.1.8.3 O ministério público como autoridade coatora, 163

2.1.9 Sentença e efeitos, 165

2.1.10 Recursos da decisão proferida em habeas corpus para o trancamento do inquérito policial, 166 2.2 Petição dirigida ao juiz competente para praticar atos no inquérito, 168

CONCLUSÃO, 170

Bibliografia, 177 


\section{INTRODUÇÃO}

A presente pesquisa tem por fim estudar o encerramento prematuro do inquérito policial que se dá por meio de seu trancamento.

Iniciar-se-á o trabalho com o estudo dos principais aspectos do inquérito policial e seu trancamento, importante para a compreensão do tema.

Diante disso, será analisada a origem, objeto, finalidade e forma de início do inquérito policial. Além disso, outras questões relevantes e específicas serão abordadas em itens próprios.

Por sua vez, será abordada a justa causa para a instauração e prosseguimento do inquérito policial, além das causas que fundamentam seu trancamento.

Serão apontadas algumas mudanças que estão por ocorrer no processo penal brasileiro em caso de aprovação pelo Congresso Nacional do projeto de lei n. 156 de 2009, em trâmite no Senado Federal, notadamente no inquérito, que é o objeto do estudo, assim como se discorrerá sobre a criação do juiz de garantias, responsável pelo controle da legalidade do inquérito policial assim como de seu trancamento.

Após, serão desenvolvidos os pontos fundamentais do habeas corpus, eis que ligados à questão do trancamento do inquérito policial, sempre apontando sua correlação com o tema, assim como o pedido formulado ao juiz competente para praticar atos no inquérito por simples petição.

Como método de elaboração da dissertação, divide-se o trabalho em capítulos, com seus respectivos itens e subitens, com desenvolvimento de cada questão de acordo com o material encontrado durante a pesquisa, mesclando a opinião pessoal sobre dados relevantes, de modo a contribuir com o fomento e a difusão do conhecimento. 
Procuraremos efetuar a redação de forma clara e objetiva, buscando demonstrar as conclusões encontradas e apontando seus respectivos fundamentos extraídos com vistas a alcançar o objetivo colimado.

Ao final, serão apontadas as conclusões alcançadas com o estudo de forma a fixar as noções fundamentais sobre o tema desenvolvido. 


\section{O TRANCAMENTO DO INQUÉRTIO POLICIAL}

\subsection{Considerações iniciais}

A palavra trancamento provém do verbo trancar que, etimologicamente, quer dizer, dentre outros significados, pôr fim a, concluir, terminar, rematar ${ }^{1}$. Pode significar também interromper ${ }^{2}$.

Assim, o vocábulo, isoladamente, significa encerramento, conclusão ou interrupção. Como é evidente, somente algo que já se iniciou pode ser concluído ou interrompido.

Unindo-se o vocábulo trancamento a inquérito policial, temos que o significado passa a ter o sentido de interrupção da investigação policial já instaurada - com o intuito de apurar o autor do fato e a materialidade do suposto delito - sob qualquer de suas formas, de ofício, mediante requisição da autoridade judiciária, do Ministério Público ou do Ministro da Justiça ou, ainda, a requerimento do ofendido ou de seu representante.

Como se trata de interrupção, ao contrário do que ocorre com seu término normal que se dá com a elaboração do relatório pela autoridade policial, o trancamento do inquérito policial se opera a partir do momento em que se torna definitiva a decisão que determinou seu encerramento prematuro.

Segundo Weber Martins Batista, "não é raro ler que a só instauração de inquérito policial não constitui coação ou constrangimento ilegal, pois se trata de simples processo extrajudicial, de cunho meramente informativo, que não tem o condão ou o efeito de levar a juízo de culpa, mas apenas à formação da opinio delicti do MP. Só quem está fora da realidade pode dizer uma coisa assim". ${ }^{3}$ Para combater esse fundamento, o autor disserta que "a abertura do inquérito policial não apenas põe o indiciado na incômoda posição de

FERREIRA, Aurélio Buarque de Holanda. Dicionário Aurélio da língua portuguesa. $5^{\text {a }}$ ed. Curitiba: Positivo, 2010, p. 2067. 1996, p. 648.

BUENO, Francisco da Silveira. Minidicionário da língua portuguesa. São Paulo: FTD,

BATISTA, Weber Martins. Trancamento de inquérito policial. Revista Forense. Rio de Janeiro: Forense, ano 90, nº 328, p. 101-104, out./dez. 1994. 
suspeito, sujeito a inúmeros constrangimentos, como o de ser conduzido perante a autoridade policial sempre que esta entender necessário, como implica na inclusão de seu nome em folha de antecedentes penais, de onde não sairá jamais, nem mesmo se arquivado o feito sem denúncia, ou se absolvido no processo contra ele proposto". ${ }^{4}$

Ainda segundo Batista, a atuação policial é discricionária, com limites fixados pelo direito, e que se ultrapassados sofrerão controle jurisdicional posterior por meio do habeas corpus, sobretudo. ${ }^{5}$

Segundo esse mesmo autor, "sendo o inquérito policial um procedimento persecutório de caráter administrativo, como tal, por essa feição, não pode estar a salvo do controle de sua legalidade. Admite-se, pois, em tese, o habeas corpus como instrumento hábil para seu trancamento, quando faltar justa causa para sua instauração (RT 412/86)" 6

Por sua vez, Greco Filho, referindo-se ao inquérito policial, assevera: "Contudo, no momento em que ele se dirige para a apuração de imputação futura provável de fato contra alguém, para que seja legítimo tem que ter justa causa, e, se não tiver, pode ser trancado mediante habeas corpus dirigido ao juiz. A autoridade policial é a autoridade coatora"?

E o que é justa causa? Discorreremos sobre o assunto no item 1.15.

De todo modo, quando ausente justa causa para o indiciamento, tal situação "vai configurar verdadeiro constrangimento ilegal, porquanto é medida que sempre estabelece algum tipo de atrito com as liberdades públicas fundamentais do indivíduo, sobretudo com a liberdade de locomoção e com o direito de ser presumido inocente". ${ }^{8}$

Paulo Roberto da Silva Passos ressalta a excepcionalidade do trancamento do inquérito policial: "Destarte, presta-se o procedimento policial à investigação da ação tida como criminosa, visando a colheita de elementos que autorizem ao Promotor de Justiça a

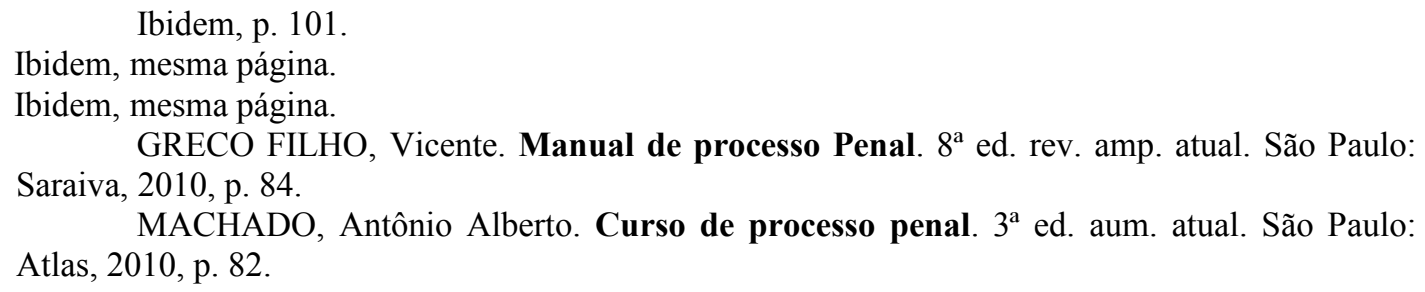


propositura da ação penal. E, por constituir o inquérito mera investigação sumária do fato que se apresenta como criminoso, via de regra, não aceitam os tribunais constitua sua instauração constrangimento. Excepcionalmente, porém, os julgados contemplam hipóteses do inquérito policial constituir-se em coação ilegal". 9

Sustenta a excepcionalidade do trancamento Manoel Messias Barbosa com o seguinte ensinamento: "Ensina Heleno Cláudio Fragoso que 'a instauração de inquérito policial não constitui constrangimento ilegal, sendo mera investigação sumária de fato que se apresenta como delituoso. Por isso mesmo, os Tribunais têm recusado habeas corpus para trancar inquérito policial. Há, no entanto, situações excepcionais em que a instauração do inquérito é de tal forma abusiva e contra a lei que não pode deixar de merecer a proteção do remédio constitucional"”. ${ }^{10}$

Nesse sentido, o Supremo Tribunal Federal decidiu no Habeas Corpus n. 63.781, mediante relatório do Ministro Sydney Sanches: "1. Pretensão de trancamento de inquérito policial que não merece prosperar. 2. Só a absoluta falta de justa causa autoriza a exclusão de inquérito e o trancamento da virtual ação penal. Em havendo fumus boni juris não deve ser impedida a apuração regular de fatos inquinados de criminosos, siet in quantum, já que a simples indiciação em inquérito policial não constitui constrangimento ilegal" (RTJ 121/79).

Marta Saad aponta o instrumento que seria adequado para o trancamento do inquérito policial: "Pode-se impetrar habeas corpus visando ao trancamento do inquérito policial instaurado para apurar fato que, a todo evidente, não constitui infração penal (art. 4. ${ }^{\circ}$ do CPP)". ${ }^{11}$

De outra banda, Scarance expõe que: "O pedido de trancamento do inquérito policial é um meio relevante para a reação do imputado". ${ }^{12}$ 1991, p. 81.

PASSOS, Paulo Roberto da Silva. Do "habeas corpus": coação ilegal. São Paulo: Edipro, BARBOSA, Manoel Messias. Inquérito policial. $7^{\mathrm{a}}$ ed. rev. atual. São Paulo: Método, 2009, p. 41. SAAD, Marta. O direito de defesa no inquérito policial. In: Coleção Estudos de Processo Penal Prof. Joaquim Canuto Mendes de Almeida São Paulo: Revista dos Tribunais, 2004, v. 9, p. 357-358.

FERNANDES, Antonio Scarance. Reação defensiva à imputação. São Paulo: Revista dos Tribunais, 2002, p. 141. 
Esse mesmo autor, na mesma obra, citando Vicente Greco assinala: "De acordo com Greco Filho, 'tranca-se a ação penal se não se forma juízo de probabilidade da ocorrência da infração e da autoria; tranca-se o inquérito se não se forma sequer juízo de possibilidade $",{ }^{13}$

A correlação entre o trancamento do inquérito policial com o trancamento da ação penal será abordada no item 1.16 .

Por outro lado, Guilherme de Souza Nucci relata o seguinte: "Admite-se que, valendo-se do habeas corpus, a pessoa eleita pela autoridade policial como suspeita possa recorrer ao Judiciário para fazer cessar o constrangimento a que está exposto, pela mera instauração de investigação infundada". ${ }^{14} \mathrm{E}$ continua: "O indiciamento, como já se viu, é mais grave ainda, pois faz anotar, definitivamente, na folha de antecedentes do sujeito a suspeita de ter ele cometido um delito". ${ }^{15}$ E prossegue: "Por tal razão, quando se perceber nítido abuso na instauração de um inquérito, (por exemplo, por fato atípico) ou a condução das investigações na direção de determinada pessoa sem a menor base de prova, é cabível o trancamento da atividade persecutória do Estado". ${ }^{16}$ E arremata: "Coíbe-se o abuso e não a atividade regular da polícia judiciária". ${ }^{17}$

Por sua vez, algumas hipóteses que justificam o trancamento do inquérito policial são apontadas por Maria Thereza Rocha de Assis Moura, nos seguintes termos: "Tanto a doutrina como a jurisprudência têm aceitado o trancamento do inquérito policial por falta de justa causa, quando o fato investigado não seja relevante para o Direito penal ou quando não haja possibilidade, em tese, de ser o investigado o autor da infração". ${ }^{18}$

Quanto à denominação, há quem sustente ser equivocado o termo trancamento.

\footnotetext{
$13 \quad$ Ibidem, p. 142.

14 NUCCI, Guilherme de Souza. Manual de processo penal e execução penal. $5^{\mathrm{a}}$ ed. rev. amp. atual. São Paulo: Revista dos Tribunais, 2008, p. 179.

$15 \quad$ Ibidem, p. 180.

16 Ibidem, mesma página.

17 Ibidem, mesma página.

18 MOURA, Maria Thereza Rocha de Assis. Justa causa para a ação penal: doutrina e jurisprudência. In: Coleção de Estudos de Processo Penal Prof. Joaquim Canuto Mendes de Almeida. São Paulo: Revista dos Tribunais, 2001, v. 5, p. 243, nota 41.
} 
Ao abordar o trancamento do inquérito policial, Marina Quezado Grosner aduz o seguinte: "O processualista penal Paulo Rangel (2003, p. 833) considera que, conquanto se utilize freqüentemente a expressão comum da prática jurídica 'trancar' o inquérito ou a ação penal, o termo, na verdade, seria incorreto: não se tranca ação penal ou inquérito policial, mas sim arquiva-se o inquérito ou extingue-se o processo com (ou sem) julgamento do mérito. A ação tem seu pedido julgado procedente ou improcedente, mas jamais trancado. A doutrina usa essa expressão ('trancar') sem que ela tenha qualquer previsão em lei. Trata o inquérito ou o processo como se fossem portas que se trancam". ${ }^{19}$ A despeito da discordância de terminologia, continua a utilizar o termo trancamento no trabalho sob o fundamento de ser imprescindível para buscar acórdãos e ter o termo também o significado de pôr fim a, concluir, terminar e rematar, essencial para a pesquisa desenvolvida sobre a forma de pôr fim ao inquérito policial ou à ação penal. ${ }^{20}$

E prossegue: "Na impetração de habeas corpus para o fim de trancar um inquérito policial ou uma ação penal, normalmente o fundamento legal está na falta de justa causa, previsto no art. 648, I, do Código de Processo Penal. Assim, alega-se, no pedido, que não há justa causa para o indiciamento do indivíduo e, portanto, para estar ele sendo investigado por determinada conduta". ${ }^{21}$

Contudo, apesar de não haver menção na lei sobre o trancamento do inquérito policial, verdade é que não se confunde com o arquivamento e esta diferença será abordada no item 1.12 .

A construção jurisprudencial acerca do trancamento e a questão da justa causa são ressaltadas por Guilherme Madeira Dezem, com a seguinte lição: “O 'trancamento do inquérito policial', trata-se de construção jurisprudencial, calcada na previsão genérica de ausência de justa causa. Entende-se que a existência de um inquérito policial, de per si, implica um constrangimento ao investigado ou indiciado, de molde que sua instauração requer a presença de justa causa, o que, no âmbito da investigação, significa a necessidade de o fato revestir-se de tipicidade e não estar extinta a punibilidade". ${ }^{22}$

\footnotetext{
19 GROSNER, Marina Quezado. A seletividade do sistema penal na jurisprudência do Superior Tribunal de Justiça: o trancamento da criminalização secundária por decisões em habeas corpus. São Paulo: Instituto Brasileiro de Ciências Criminais, 2008, p. 78.

$20 \quad$ Ibidem, p. 78-79.

$21 \quad$ Ibidem, p. 79.
} 
E conclui: "Dessarte, para a instauração de um inquérito policial prevalece o entendimento de que são consideradas a tipicidade do fato objeto da investigação e, a par disso, não estar extinta a punibilidade, sob pena de a existência desse procedimento administrativo consubstanciar uma coação ilegal ao investigado/indiciado. Para rechaçar constrangimentos ilegais, a jurisprudência criou o mecanismo do trancamento do inquérito policial por falta de justa causa, a ser pleiteado pela via de ação de habeas corpus. Julgada procedente deve, o juiz ou tribunal, determinar a imediata paralisação das investigações, encerrando o inquérito policial indevidamente instaurado". ${ }^{23}$

Portanto, fala-se em trancamento do inquérito policial quando ausente justa causa para seu prosseguimento. Sendo assim, não havendo justa causa, pode o inquérito policial ser trancado.

Aliás, é intuitivo que o trancamento ocorra na hipótese de inquérito policial já instaurado, visto que se há recurso judicial para evitar sua abertura, não se fala em trancamento, já que não se impede o prosseguimento daquilo que sequer teve início.

Mas toda e qualquer situação causará constrangimento, é dizer, basta o indiciamento para se afirmar que não há justa causa para a instauração do inquérito policial?

Não é bem assim.

De regra, não existe constrangimento ilegal pela simples instauração do inquérito policial em si, haja vista que constitui um conjunto de atos para apurar a ocorrência de uma infração penal e descobrir seu autor. Claro que se iniciada a investigação com abuso, com o intuito de causar incômodos a um indivíduo, será caso de trancamento do inquérito policial. $^{24}$

O trancamento do inquérito policial só pode ser configurado em hipóteses excepcionais, quando faltar justa causa para sua instauração e prosseguimento.

22 DEZEM, Guilherme Madeira. Prática penal. In: MACHADO, Ângela C. Cangiano; DEZEM, Guilherme Madeira; JUNQUEIRA, Gustavo Octaviano Diniz et al. Coleção prática forense. $6^{a}$ ed. rev. atual. São Paulo: Revista dos Tribunais, 2009, v. 6, p. 28.

Ibidem, p. 29.

24 SALLES JUNIOR, Romeu de Almeida. Inquérito policial. $3^{\text {a }}$ ed. Curitiba: Juruá, 2010, p. 35. 
É evidente a repercussão social que decorre da instauração de um inquérito policial. O investigado estará sujeito a diversas obrigações, como comparecimento pessoal à delegacia de polícia quantas vezes for convocado pela autoridade policial, identificação datiloscópica, processo de reconhecimento pessoal, enfim, uma série de atos praticados durante sua tramitação que certamente lhe causarão transtornos. Quando todo esse constrangimento decorrer de instauração de inquérito policial com evidente abuso de poder ou ilegalidade, claro se torna o direito de o investigado pedir seu trancamento, para que se coloque fim às ilegalidades e aos constrangimentos por que passa.

Sobre esse aspecto, socorremo-nos mais uma vez de Manoel Messias Barbosa: “Apenas a flagrante, indiscutível e evidente falta de justa causa no envolvimento do suspeito no delito investigado, justifica o trancamento de inquérito policial, instaurado para a apuração de eventual ilícito penal a ele imputado. Na medida em que paire alguma procedência, ou mesmo simples possibilidade de veracidade da imputação, a investigação se faz indispensável, cumpridas todas as formalidades impostas pela lei processual, uma das quais é, exatamente, o indiciamento do apontado autor da infração investigada". ${ }^{25}$

Destarte, em princípio, quando a autoridade policial tiver conhecimento de um delito e se houver indícios de que o investigado seja seu autor, não se justifica o trancamento, não se falando em constrangimento ilegal.

Ademais, é possível que ao final das investigações se conclua que o suposto autor do fato não o cometeu, de modo que a instauração regular do inquérito policial, com o indiciamento daquele sobre o qual pesa a suspeita do cometimento do delito, com base em indícios mínimos que o apontem como autor do delito, não gera constrangimento ilegal, não havendo razão para que seja trancado de forma prematura.

Até porque, como conjunto de atos, o inquérito policial tem por fim apurar o autor do fato e a materialidade do delito e serve de base para a formação da opinio delicti por parte do autor da ação penal. Somente em casos onde seja fácil a constatação do abuso, da ilegalidade, quando transparecer a ausência de justa causa é que resta justificado o trancamento das investigações.

25 BARBOSA, Manoel Messias. Inquérito policial. $7^{\text {a }}$ ed. rev. atual. São Paulo: Método, 2009 , p. 42. 
Assim, como é evidente, não é qualquer hipótese que autoriza o trancamento do inquérito policial.

Desse modo, o trancamento do inquérito policial é medida em princípio excepcional, quando for manifesta e indiscutível a ilegalidade e o abuso de poder que se mostrem totalmente claros dentro da investigação criminal. ${ }^{26}$

Sendo assim, o indiciamento da pessoa sobre a qual recaem provas de ser autora de uma infração penal não lhe causa constrangimento, ficando autorizada a autoridade policial a tomar todas as providências necessárias para proceder à investigação, inclusive aquelas previstas no art. $6^{\circ}$ do Código de Processo Penal, sem prejuízo das demais medidas legais cabíveis para o bom andamento do inquérito e apuração dos todos os elementos e circunstâncias do crime.

Segundo Weber Martins Batista, apesar de a abertura do inquérito policial constranger o indiciado, este constrangimento nem sempre será ilegal, o que ocorre quando o delito puder dar ensejo a ação penal pública e houver indícios suficientes de que ele seja seu autor, tornando obrigatória sua instauração. ${ }^{27}$ Neste sentido cita aresto relatado pelo Ministro do Supremo Tribunal Federal Sidney Sanches, segundo o qual o inquérito policial "é um procedimento investigatório legítimo, cujo desenvolvimento e desfecho não podem ser obstados por habeas corpus, para que não se incorra no risco de coarctar as atividades próprias da polícia judiciária e do MP (RTJ, 125/1.078)". ${ }^{28}$

Portanto, ausente o pressuposto da justa causa para instauração e prosseguimento do inquérito policial, possível seu trancamento. Como veremos no decorrer do estudo, além do pressuposto da falta de justa causa, possível será o trancamento se presente uma das causas ou hipóteses que podem fundamentar o pedido, de modo que o campo de atuação dessa medida é um pouco mais abrangente do que se tem defendido, e trataremos desse aspecto durante o desenvolvimento do tema conforme se verá mais adiante.

\footnotetext{
FELDENS, Luciano; SCHMIDT, Andrei Zenkner. Investigação criminal e ação penal. $2^{\mathrm{a}}$ ed. rev. amp. atual. Porto Alegre: Livraria do Advogado, 2007, p. 28. Janeiro: Forense, ano 90, nº 328, p. 101-104, out./dez. 1994.

$28 \quad$ Ibidem, p. 101.
} 
O inquérito policial surgiu no Brasil com o advento da Lei n. 2.033, de 24-9-1871, regulamentada pelo Decreto-lei n. 4.824, de 22-11-1871, que o conceituava da seguinte forma no art. 42, in verbis:

Art. 42. O inquerito policial consiste em todas as diligencias necessárias para o descobrimento dos factos criminosos, de suas circumstancias e dos seus autores e complices; e deve ser reduzido a instrumento escripto, observando-se nelle o seguinte (...).

Atualmente, o conceito de inquérito policial pode ser subtraído do art. $4^{\circ}$ do Código de Processo Penal, que o define de forma indireta. Esse dispositivo dispõe, in verbis:

Art. $4^{\circ}$. A polícia judiciária será exercida pelas autoridades policiais no território de suas respectivas circunscrições e terá por fim a apuração das infrações penais e da sua autoria.

A Lei n. 9.043, de 9-5-1995, deu ao dispositivo essa redação para o fim de corrigir o equívoco da redação anterior que definia que a polícia judiciária seria exercida pelas autoridades policiais no território de suas respectivas jurisdições, quando, na verdade, só os membros do Poder Judiciário é que têm jurisdição, que é o poder-dever de dizer o direito.

As infrações penais de menor potencial ofensivo, assim definidas pelo art. 61 da Lei n. 9.099, de 26-9-1995, na redação que lhe foi dada pelo art. $1^{\circ}$ da Lei n. 11.313, de 286-2006, como as contravenções penais e os crimes a que a lei comine pena máxima não superior a dois anos, cumulada ou não com multa, dispensam a instauração do inquérito policial, eis que basta a lavratura de simples termo circunstanciado (art. 69). No âmbito da Justiça Federal, as infrações penais de menor potencial ofensivo também dispensam a instauração de inquérito policial, sendo bastante a lavratura de termo circunstanciado (art. $1^{\mathrm{o}}$ e art. $2^{\circ}$ da Lei n. 10.259, de 12-7-2001). 
Há quem defina o inquérito policial como um conjunto de diligências realizadas pela polícia judiciária para a apuração de uma infração penal e sua autoria, apontando, ainda, sua finalidade que é servir de base para a propositura da ação penal. ${ }^{29}$

Por outro lado, há quem sustente ser o inquérito policial um procedimento administrativo. ${ }^{30}$

Contudo, o inquérito policial não pode ser definido como procedimento administrativo, eis que ele não possui sua característica essencial. Neste sentido, Scarance esclarece que "sequer o inquérito é procedimento, pois falta-lhe característica essencial do procedimento, ou seja, a formação por atos que devam obedecer a uma sequência predeterminada pela lei, em que, após a prática de um ato, passa-se à do seguinte até o último da série, numa ordem a ser necessariamente observada". ${ }^{31}$

Para Greco Filho o inquérito policial é uma peça escrita. ${ }^{32}$ Por fim, há quem o denomine como conjunto de atos. ${ }^{33}$

De outro lado, os delegados de polícia presidem o inquérito policial instaurado para apuração de crimes que serão julgados pela justiça estadual (Constituição Federal, art. 144, $\S 4^{\circ}$ ), visto que nos crimes que serão julgados pela justiça federal (Constituição Federal, art. 109 e art. 144, $\S 1^{\mathrm{o}}$ e incisos; Lei n. 5.010, de 30-5-1966, art. 10) compete sua presidência ao delegado de polícia federal.

$29 \quad$ SALLES JUNIOR, Romeu de Almeida. Inquérito policial. $3^{\mathrm{a}}$ ed. Curitiba: Juruá, 2010, p. 11; CAPEZ, Fernando. Curso de processo penal. $18^{\mathrm{a}}$ ed. São Paulo: Saraiva, 2011, p. 109; MOSSIN, Heráclito Antônio. Curso de processo penal. $2^{a}$ ed. São Paulo: Atlas, 1998, vol. 1, p. 162; NOGUEIRA, Paulo Lúcio. Curso completo de processo penal. $7^{a}$ ed. rev. amp. atual. São Paulo: Saraiva, 1993, p. 35.

$30 \quad$ BARBOSA, Manoel Messias. Inquérito policial. $7^{\mathrm{a}}$ ed. rev. atual. São Paulo: Método, 2009, p. 27; CARVALHO, Djalma Eutímio de. Curso de processo penal. $2^{\mathrm{a}}$ ed. rev. atual. Rio de Janeiro: Forense, 2009, p. 40; LIMA, Marcellus Polastri. Manual de processo penal. $5^{\text {a }}$ ed. Rio de Janeiro: Lumen Juris, 2010, p. 65; MIRABETE, Julio Fabbrini. Processo penal. $7^{\text {a }}$ ed. rev. atual. São Paulo: Atlas, 1997, p. 79.

FERNANDES, Antonio Scarance. Processo penal constitucional. $6^{\text {a }}$ ed. rev. amp. atual. São Paulo: Revista dos Tribunais, 2010, p. 62.

GRECO FILHO, Vicente. Manual de processo Penal. $8^{\mathrm{a}}$ ed. rev. amp. atual. São Paulo: Saraiva, 2010, p. 77.

MACHADO, Antônio Alberto. Curso de processo penal. $3^{\text {a }}$ ed. aum. atual. São Paulo: Atlas, 2010, p. 53. 
Se o inquérito policial é instaurado com o objetivo de investigar a prática do crime e descobrir quem é o seu autor, como é evidente, ele é instaurado somente após a ocorrência da infração penal, visto que à polícia judiciária não compete exercer a polícia preventiva, esta a cargo dos órgãos da polícia militar (Constituição Federal, art. 144, $\S 5^{\circ}$ ).

Além disso, os atos nele praticados devem ser documentados, o que justifica sua escrituração.

No inquérito policial pratica-se o ato de inquirir, isto é, procurar informações sobre algo, colher informações acerca de um fato, perquirir. ${ }^{34}$

Destarte, com base em tais ensinamentos, é possível definir o inquérito policial como conjunto de atos de natureza investigatória, informativa, instaurado para a apuração das infrações penais e da sua autoria, sob a responsabilidade da polícia judiciária.

Assim, o inquérito serve para investigar infrações penais e visa apurar quem foi seu autor.

\subsection{Objeto e finalidade do inquérito policial}

O objeto do inquérito policial será a notícia-crime dando conta da existência da autoria e da materialidade.

A finalidade do inquérito policial é servir de instrumento para a propositura da ação penal pelo Ministério Público, nos casos de ação penal pública, ou ao ofendido, nas hipóteses de ação penal privada. ${ }^{35}$ Essa finalidade de fornecer subsídios ao titular da ação penal denota o caráter instrumental do inquérito policial, que não tem por objetivo a conclusão de juízo de culpa, este a ser aferido em eventual e futura ação penal. ${ }^{36}$

\footnotetext{
LOPES JUNIOR, Aury. Direito processual penal e sua conformidade constitucional. $4^{\mathrm{a}}$ ed. rev. atual. Rio de Janeiro: Lumen Juris, 2009, p. 255.

FELDENS, Luciano; SCHMIDT, Andrei Zenkner. Investigação criminal e ação penal. $2^{\mathrm{a}}$ ed. rev. amp. atual. Porto Alegre: Livraria do Advogado, 2007, p. 14.

$36 \quad$ Ibidem, mesma página.
} 
Daí a razão de o inquérito policial ser denominado conjunto de atos, com função primordial de investigar autoria e materialidade, para que tais elementos autorizem o titular da ação penal requerer a instauração da ação penal. ${ }^{37}$

Portanto, essa finalidade de dar subsídios ao titular da ação penal, seja ela pública ou privada, de que há elementos suficientes para sua propositura serve para a formação da opinio delicti do acusador e, ao mesmo tempo, para demonstrar a existência de provas suficientes para que a ação penal tenha justa causa. A justa causa, na ação penal, é o "conjunto de elementos probatórios razoáveis sobre a existência do crime e da autoria". ${ }^{38}$

Por outro lado, além da finalidade de formar a opinio delicti do acusador, o inquérito policial serve para demonstrar ao juiz a presença da justa causa para o recebimento da denúncia ou queixa, oportunidade em que analisará os elementos colhidos durante a investigação e apreciará as razões e fundamentos utilizados pelo acusador ao propor a ação penal, quando exercerá o juízo de valor necessário para acatar tais provas e argumentos ao receber a peça inicial da ação penal ou afastá-los, com as suas razões, ao rejeitar a denúncia ou queixa (art. 395, III do Código de Processo Penal).

A investigação se dá por meio da apuração. Apurar a infração penal é colher informações a respeito do fato criminoso por meio de oitiva de testemunhas, vítima, realização de perícias, buscas e apreensões e outras circunstâncias que esclareçam o fato. Apurar a autoria é descobrir quem praticou o delito. ${ }^{39}$

Compete à autoridade policial, assim, colher todas as provas possíveis no decorrer da investigação. $\mathrm{O}$ art. $6^{\circ}$ e o art. $7^{\circ}$ do Código de Processo Penal lhe servem de parâmetro para alcançar o fim almejado. Mas não deve a autoridade se descurar do fato de que seu trabalho visa possibilitar a propositura da ação penal. Assim, deve ela encerrar o inquérito policial quando verificar que estão suficientemente apuradas a autoria e materialidade do delito, bem como outras circunstâncias relevantes. ${ }^{40}$

\footnotetext{
37 SILVA, Luiz Cláudio; SILVA, Franklyn Roger Alves. Manual de processo e prática penal. $4^{\text {a }}$ ed. rev. amp. atual. Rio de Janeiro: Forense, 2010, p. 385.

GRECO FILHO, Vicente. Manual de processo penal. $8^{\mathrm{a}}$ ed. rev. amp. atual. São Paulo: Saraiva, 2010, p. 78.

TOURINHO FILHO, Fernando da Costa. Manual de processo penal. $14^{\mathrm{a}}$ ed. São Paulo: Saraiva, 2011, p. 111.

GRECO FILHO, Vicente. Manual de processo penal. $8^{\mathrm{a}}$ ed. rev. amp. atual. São Paulo: Saraiva, 2010, p. 81.
} 


\subsection{Competência e trancamento}

O termo competência trata das atribuições da autoridade policial ${ }^{41}$, não se confundindo com a delimitação da jurisdição das autoridades judiciárias.

A autoridade policial deve atuar, em princípio, dentro do território de sua respectiva circunscrição (art. $4^{\circ}$ do Código de Processo Penal). Quer isso dizer que se um delito se consumou no território da circunscrição na qual atua determinada autoridade policial, deverá ela agir, instaurando o inquérito policial, para investigar a autoria e a materialidade do delito (princípio da obrigatoriedade $-\operatorname{artigos} 5^{\circ}$ e $6^{\circ}$ do Código de Processo Penal).

A despeito disso, pode uma autoridade policial atuar no interior da circunscrição de outra, quando necessário para o cumprimento de suas funções. O art. 22 do Código de Processo Penal dispõe que nos locais onde houver mais de uma circunscrição policial, a autoridade com exercício em uma delas poderá, nos inquéritos a que esteja procedendo, ordenar diligências em circunscrição de outra, independentemente de precatórias ou requisições, e bem assim providenciará, até que compareça a autoridade competente, sobre qualquer fato que ocorra em sua presença, noutra circunscrição.

A pergunta que se faz é se é possível o trancamento do inquérito policial por incompetência da autoridade que o preside ou o instaurou? Como exemplo, cita-se a hipótese de inquérito policial instaurado e presidido por Delegado de Polícia para apuração de crime cuja competência para sua apuração e julgamento sejam da polícia federal e da justiça federal ou mesmo o caso de instauração de inquérito policial para apuração de fato ocorrido em outro Estado da Federação.

\section{Entendemos que não.}

Por ora, o que se pode dizer é que ao ser constatada a incompetência da autoridade policial para instaurar e presidir determinado inquérito policial, deverá o interessado 
requerer seu encaminhamento para o órgão policial competente, mas nunca será hipótese de trancamento, haja vista que a questão da competência não se confunde com a justa causa para instauração do inquérito policial.

\subsection{Investigações pelo ministério público e trancamento}

O Ministério Público pode realizar investigações, substituindo as funções da autoridade policial? Se a resposta for positiva, pode o inquérito policial ser trancado após as investigações realizadas pelo Ministério Público?

$\mathrm{O}$ art. $144, \S 4^{\circ}$ da Constituição Federal dispõe competir às polícias civis, dirigidas por delegados de polícia de carreira, as funções de polícia judiciária e a apuração de infrações penais, exceto as militares, ressalvando-se a competência da União. As funções de polícia judiciária da União, por sua vez, são destinadas à polícia federal (art. 144, $\S 1^{\circ}$ da Constituição Federal).

Esses dispositivos constitucionais não atribuem, no entanto, a exclusividade da função de polícia judiciária à polícia civil e à polícia federal.

Tanto isso é verdade, que existem casos previstos expressamente na própria Constituição ou em leis especiais determinando a competência de determinadas autoridades para presidir inquéritos policiais. São as hipóteses decorrentes da prerrogativa de função, tal qual ocorre com os crimes praticados por juízes de direito, cuja presidência do inquérito competirá a membro do Tribunal ou Órgão Especial ao qual está vinculado (art. 33, parágrafo único da Lei Complementar n. 35, de 14-3-1979), de crimes praticados por promotores de justiça, cuja presidência do inquérito competirá ao Procurador-Geral de Justiça (art. 41, parágrafo único da Lei n. 8.625 de 12-2-1993).

Há casos, ainda, de outras autoridades que possuem foro privilegiado em razão da importância de suas funções institucionais, com ocorre com o Presidente da República, Deputados Federais e Senadores, cuja competência para o julgamento das infrações penais comuns é do Supremo Tribunal Federal (art. 102, I, b, da Constituição Federal). 
Assim, o argumento da falta de previsão legal que autorize a atividade investigativa pelo Ministério Público não procede.

Como veremos, os dispositivos constitucionais e legais que serão citados para fundamentar o entendimento da possibilidade de o Ministério Público proceder a investigações já existem e corroboram essa afirmação.

Como é cediço, não há necessidade de previsão absolutamente expressa no sentido da possibilidade do exercício de um direito, seja por um órgão estatal, seja por particulares. Desde que seja possível, por meio de interpretação dos dispositivos constitucionais e legais extrair uma conclusão a possibilitar tal exercício e a fundamentar o início de determinada atividade estatal, isso ocorrerá por meio da análise desses dispositivos e sua aplicação prática, sempre com respeito aos direitos de quem puder ser prejudicado por tal atuação.

Por outro lado, é possível concluir que a Constituição Federal e a Lei Orgânica do Ministério Público permitem a investigação por tal órgão.

O art. 129, VI da Constituição Federal permite aos membros do Ministério Público expedir notificações e requisitar informações e documentos para instruir procedimentos administrativos de sua competência.

Por sua vez, o art. 26, I, $a$ e $b$ e II da Lei Orgânica do Ministério Público (Lei n. 8.625, de 12-2-1993) dispõe ser possível ao membro do Ministério Público instaurar procedimentos administrativos, expedir notificações, requisitar informações, exames periciais e documentos de autoridades, órgão e entidades da administração direta ou indireta, além de entidades privadas.

De outro lado, o art. 129, VII da Constituição Federal determina competir ao Ministério Público exercer o controle externo da atividade policial, de modo a ser possível seu acompanhamento. Já o inciso VIII do mesmo dispositivo permite que o Ministério Público requisite diligências investigatórias e a instauração do inquérito policial, o que é repetido pela Lei n. 8.625, de 12-2-1993 (art. 26, IV). 
Por conta disso, tais dispositivos constitucionais e legais permitem concluir ser possível ao Ministério Público proceder a investigações, instaurando investigação administrativa em seu âmbito interno para a apuração de determinados crimes, desde que, à evidência, seja hipótese de crime de ação penal pública incondicionada, visto que a ação penal condicionada à representação e a ação penal privada dependem de representação e da iniciativa do ofendido ou de quem tenha qualidade para representá-lo.

De outro lado, no sistema acusatório como o nosso, há separação clara de funções, cabendo às partes propor e demonstrar as provas pertinentes em busca da apuração correta das infrações penais, de modo que não há nenhum impedimento legal que impeça o Ministério Público de realizar investigações.

Outra razão a autorizar essa conclusão decorre da possibilidade de a própria defesa poder proceder à investigação paralela.

O que não é possível e recomendável é o Ministério Público tentar investigar toda e qualquer infração penal, substituindo totalmente a atividade policial, visto que, aí sim, estaria aniquilando completamente a atividade de investigação das polícias, invertendo o sistema constitucional por completo, o que não lhe foi autorizado pela Constituição Federal e pela lei.

Sendo assim, por tais fundamentos, conclui-se que é possível ao Ministério Público realizar investigações.

É importante ressaltar que em doutrina, contudo, a posição aqui defendida não é pacífica. Rogério Lauria Tucci sustenta, com base nos mesmos dispositivos constitucionais e legais acima citados, além de outros, não ser possível ao Ministério Público realizar investigações. ${ }^{42}$ De um modo geral, aponta argumentos históricos para afirmar que sempre houve distinção entre as funções da polícia judiciária e do Ministério Público.

Além disso, não haveria infraestrutura para a instituição do promotor-investigador e essa atuação importaria em afronta à garantia constitucional do devido processo legal em

42 TUCCI, Rogério Lauria. Ministério público e investigação criminal. São Paulo: Revista dos Tribunais, 2004, p. 74-78. 
razão do desequilíbrio entre as partes na persecução criminal, visto que o órgão do Ministério Público atuaria na colheita de provas sempre em direção ao resultado do êxito na posterior postulação condenatória. ${ }^{43}$

Afirma em dois trechos, de forma incisiva, a diferença entre as funções da polícia judiciária e a do Ministério Público: "Como fica fácil de perceber, o legislador brasileiro, tanto no plano constitucional, como no infraconstitucional, estabeleceu, destarte, gritante distinção entre as funções ministeriais no campo penal e as exercentes em sede extrapenal". ${ }^{44}$ E logo adiante: "Ora, se o inquérito de que se trata, em âmbito penal, é policial, somente à polícia, e a mais ninguém, será dado realizá-lo!". 45

Não cabe aqui alongar a discussão, visto que foge aos objetivos do presente estudo, mas, em verdade, nenhum dispositivo constitucional ou legal impede a atuação do Ministério Público em proceder a investigações criminais como acima ficou assentado.

Ao contrário, a Constituição Federal e a Lei Orgânica do Ministério Público permitem concluir no sentido de ser possível tal proceder. Não há risco de desequilíbrio entre as partes na persecução penal ou afronta ao devido processo penal, uma vez que nada impede a própria defesa realizar suas investigações.

Ademais, não há risco ao contraditório, eis que esse será exercido em eventual ação penal, mediante o controle do órgão jurisdicional imparcial, que analisará se as provas produzidas na investigação a cargo do Ministério Público podem ser utilizadas na fase judicial e se atentam ou não contra a Constituição ou contra normas infraconstitucionais.

Por fim, a questão está sendo debatida no Supremo Tribunal Federal no Recurso Extraordinário n. 593727, cujo relator é o Ministro Cezar Peluso, mas até a presente data ainda não foi definitivamente julgado.

A despeito disso, sustentamos ser possível ao Ministério Público, com as cautelas necessárias, realizar investigações em caso de ação penal pública incondicionada.

\begin{tabular}{ll}
\hline 43 & Ibidem, p. 83. \\
44 & Ibidem, p. 77. \\
45 & Ibidem, p. 78.
\end{tabular}


Diante da resposta positiva, é possível ser trancado inquérito instaurado após a investigação realizada pelo Ministério Público?

É preciso diferenciar as situações. Duas hipóteses podem ocorrer. Na primeira, realizadas as investigações, o Ministério Público entende por bem requisitar a instauração de inquérito policial e anexar as informações colhidas para posterior propositura da ação penal pública; na segunda, as próprias peças e documentos do instrumento utilizado para proceder às investigações são usados para a propositura da ação penal pública, dispensando-se o inquérito. Na primeira hipótese, não há a menor dúvida da possibilidade de trancamento, nos casos em que é cabível - e que serão estudados adiante -, visto que se trata de inquérito policial como qualquer outro; na segunda hipótese, como é evidente, não se fala em trancamento, eis que sequer existe o inquérito. Nesse último caso, o que se pode falar é em trancamento da ação penal, mas tal análise foge aos interesses do presente estudo.

A Constituição Federal de 1988 tratou das comissões no Congresso Nacional no art. 58.

Esse dispositivo constitucional dividiu as comissões em permanentes e temporárias, constituídas na forma e com as atribuições previstas nos regimentos internos da Câmara dos Deputados e do Senado Federal (art. 58, caput da Constituição Federal).

Além disso, assegura, na constituição das comissões, a representação proporcional dos partidos ou dos blocos parlamentares $\left(\operatorname{art.} 58, \S 1^{\circ}\right)$.

Por outro lado, aborda a competência das comissões em razão da matéria (art. 58, § $2^{\mathrm{o})}$

A norma ainda regula os poderes das comissões parlamentares de inquérito (art. 58, $\left.\S 3^{\circ}\right)$. 
Segundo esse último dispositivo, as comissões parlamentares de inquérito terão poderes de investigação próprios das autoridades judiciais, além de outros previstos nos regimentos internos das Casas do Congresso Nacional, e nelas serão criadas, em conjunto ou separadamente, mediante requerimento de um terço de seus membros, para a apuração de fato determinado e por prazo certo, sendo suas conclusões, se o caso, encaminhadas ao Ministério Público, para que promova a responsabilidade civil ou criminal dos infratores.

Destarte, como visto, a comissão parlamentar de inquérito tem natureza administrativa e tem por fim investigar fato determinado. Assim, o fato investigado deve ser definido claramente.

A conclusão dos trabalhos deve ser feita em prazo certo.

Contudo, importante para o presente trabalho é compreender o alcance e o conteúdo dos poderes das comissões parlamentares de inquérito. O que quis dizer, exatamente, o legislador constitucional ao definir que elas atuam com poderes de investigação próprios das autoridades judiciais, além de outros previstos nos regimentos internos das duas Casas Legislativas?

Quanto ao conteúdo, é evidente que o fato determinado deve ter relação com o interesse público. Não se justifica a criação de comissão para apurar fato de interesse meramente privado, em questões que não tenham qualquer relação com o funcionamento da Administração Pública, ou mesmo se imiscuir a comissão em investigar fatos rotineiros e de menor importância, estes a cargo dos demais órgãos reconhecidos e definidos no corpo da própria Constituição Federal que, no caso, são de atribuição das polícias (civil ou federal).

Como limite de atuação, deve a comissão parlamentar de inquérito respeitar os direitos e garantias fundamentais do investigado. Dentre tais direitos, destacam-se o de não se autoincriminar, de manter-se calado, assistência de defensor, contraditório, devendo a comissão agir "nos limites estritos dos poderes que lhe foram outorgados". ${ }^{46}$

46 FERNANDES, Antonio Scarance. Processo penal constitucional. $6^{\mathrm{a}}$ ed. rev. amp. atual. São Paulo: Revista dos Tribunais, 2010, p. 245. 
Compete ao Supremo Tribunal Federal processar e julgar, originariamente, mandados de segurança e habeas corpus impetrados contra atos praticados pelas comissões parlamentares de inquérito (art. 102, I, $d$ e $i$, da Constituição Federal).

Para a consecução de seus objetivos, "as comissões devem, em princípio, ser dotadas dos meios instrumentais destinados a tornar efetivos seus poderes investigatórios". ${ }^{47}$ Apesar disso, não são ilimitados estes poderes, tendo como limite os princípios constitucionais.

Podem as comissões parlamentares de inquérito inquirir testemunhas, requisitar documentos, enfim, proceder de modo a bem desempenhar suas atribuições e alcançar suas finalidades.

As comissões parlamentares de inquérito podem decretar a quebra de sigilo bancário, fiscal e telefônico, este último somente no tocante aos dados e registros telefônicos, visto que a interceptação telefônica só pode ser decretada pelo Poder Judiciário, tendo em vista se tratar de questão ligada à reserva de jurisdição, como ocorre, também, com a busca domiciliar (art. $5^{\circ}$, XI da Constituição Federal). Além disso, os dados obtidos devem permanecer em sigilo, só podendo ser divulgados em casos excepcionais, no relatório final ou em comunicação destinada ao Ministério Público. ${ }^{48}$

Não pode a comissão parlamentar de inquérito decretar a prisão de quem quer que seja, eis que tal função também se encontra na esfera de competência dos órgãos jurisdicionais.

Quanto ao prazo determinado, pode ele ser prorrogado, mas terá como limite o término da legislatura.

A Lei n. 10.001, de 4-9-2000 regulamentou o art. 58, § $3^{\circ}$ da Constituição Federal, para o fim de determinar que o relatório final da comissão parlamentar de inquérito seja encaminhado aos chefes do Ministério Público da União e dos Estados, ou às autoridades administrativas ou judiciais com poder de decisão para a prática de atos de sua

\begin{tabular}{lr}
\hline 47 & Ibidem, p. 246. \\
48 & Ibidem, p. 247.
\end{tabular}


competência, possuindo prioridade os processos ou procedimentos instaurados em decorrência de suas conclusões, à exceção do habeas corpus, habeas data e o mandado de segurança (art. $3^{\circ}$ da Lei n. 10.001, de 4-9-2000).

É possível o trancamento de tais investigações? Pela mesma razão que não é possível o trancamento das investigações realizadas pelo Ministério Público quando não requisita a instauração de inquérito policial, ante a não existência desse instrumento, entendemos não ser possível o trancamento das investigações realizadas pelas comissões parlamentares de inquérito. O que se pode cogitar, da mesma forma, é o trancamento de eventual ação penal, mas não da investigação propriamente dita.

Além disso, como o artigo $3^{\circ}$ da Lei n. 10.001, de 4-9-2000 permite o encaminhamento do relatório final às autoridades administrativas, não se excluindo, assim, as autoridades policiais, é possível que esse relatório fundamente a abertura de inquérito policial determinada pela autoridade policial competente e, nesse caso, desde que presentes as hipóteses em que é cabível, ser requerido seu trancamento.

\subsection{Indiciamento e trancamento}

$\mathrm{O}$ indiciamento é um ato formal realizado pela autoridade policial e consiste em imputar ao suspeito seu envolvimento com a infração penal investigada. ${ }^{49}$

O indiciamento só pode ser realizado quando estiver demonstrada a materialidade do delito e houver indícios de que o suspeito seja seu autor. É ato privativo da autoridade policial. ${ }^{50}$

Não há regulamentação de como deve ser realizado o indiciamento, o que pode gerar abusos e desvios graves, visto que sua falta possibilita sua realização sem a devida motivação. Melhor seria se houvesse a mudança proposta no Projeto de Código de Processo Penal n. 4.209/2001 - que não vingou - segundo a qual o indiciamento deveria ser

\footnotetext{
49 GRECO FILHO, Vicente. Manual de processo penal. $8^{\mathrm{a}}$ ed. rev. amp. atual. São Paulo: Saraiva, 2010, p. 82.

CARVALHO, Djalma Eutímio de. Curso de processo penal. $2^{\mathrm{a}}$ ed. rev. atual. Rio de Janeiro: Forense, 2009, p. 51.
} 
fundamentado pela autoridade policial, onde a pessoa envolvida na persecução penal passaria da situação de investigado para indiciado (artigos $8^{\circ}$ e 16 do projeto). ${ }^{51}$

Se não houver justa causa para o indiciamento, mas, a despeito disso, houver sua realização, constituirá tal ato constrangimento ilegal, a ser corrigido por meio de habeas corpus. $^{52}$

Não se admite indiciamento daquele que possui foro privilegiado por prerrogativa de função. ${ }^{53}$ Isso ocorre porque se o investigado possuir foro privilegiado, o inquérito policial deverá ser encaminhado à autoridade ou órgão competente para o processamento $\mathrm{e}$ julgamento da pessoa que possuir tal prerrogativa.

Este ato inclui a apuração dos dados do indiciado, sua vida pregressa, identificação datiloscópica e civil, se presente. Se ausente, o indiciamento se fará de forma indireta, com a colheita de dados por outros meios e fontes diversos. ${ }^{54}$

O Código de Processo Penal não regula o momento adequado para o indiciamento. Porém, este pode ocorrer por ocasião da lavratura do auto de prisão em flagrante (art. 304 do Código de Processo Penal) ou quando a autoridade policial entender que há elementos suficientes para imputar o envolvimento do investigado com a infração penal. ${ }^{55}$

Em caso de trancamento do inquérito policial, automaticamente está anulado o indiciamento do suspeito.

Por outro lado, o trancamento do inquérito policial deve ser requerido antes ou depois do indiciamento, levando-se em conta que este é o ato formal que imputa ao suspeito seu envolvimento com a infração penal?

\footnotetext{
TUCCI, Rogério Lauria. Investigação criminal no projeto de reforma do código de processo penal. Revista do Advogado. São Paulo: Associação dos Advogados de São Paulo, ano XXIV, $n^{\circ}$ 78, p. 103-110, set. 2004. Janeiro: Forense, 2009, p. 51.

53 Ibidem, mesma página. Saraiva, 2010, p. 82

GRECO FILHO, Vicente. Manual de processo penal. $8^{\mathrm{a}}$ ed. rev. amp. atual. São Paulo:

$55 \quad$ Ibidem, p. 83.
} 
Entendemos que carece o suspeito ainda não indiciado de interesse processual para requerer o trancamento do inquérito policial antes do indiciamento, visto que somente com o indiciamento é que se imputa a ele o envolvimento com a infração penal investigada. Daí que o trancamento do inquérito policial somente deve ser requerido depois do indiciamento do suspeito.

\section{$1.8 \quad$ Inicio do inquérito policial}

\subsection{1}

\section{Crimes de ação penal pública incondicionada}

O presente item é importante, na medida em que trata do início do inquérito policial, dentre outras hipóteses, por requisição judicial ou do Ministério Público e isso influencia no pedido de trancamento, visto que se relaciona com o aspecto da competência para apreciação de tal pedido.

$\mathrm{O}$ inquérito policial tem início por diversos meios, dependendo da natureza do crime a ser investigado.

Quando o crime a ser apurado for daqueles considerados de ação penal pública incondicionada, ou seja, quando a propositura da ação penal pelo Ministério Público não depender de qualquer condição, a autoridade da polícia judiciária competente para a instauração do inquérito policial a ele dará início das seguintes formas: de oficio, quando tomar conhecimento diretamente da ocorrência do crime; mediante requisição da autoridade judiciária ou do Ministério Público; e, por fim, mediante requerimento do ofendido ou de quem tiver qualidade para representá-lo (art. 5, I e II do Código de Processo Penal).

E quando a ação penal é pública? Segundo o art. 100 do Código Penal, a ação penal é pública, salvo quando a lei expressamente a declara privativa do ofendido, ou seja, sempre que a lei penal não dispuser ser a ação penal privativa do ofendido, esta será pública, podendo ser incondicionada, quando independe de qualquer condição, ou 
condicionada à representação do ofendido ou de requisição do Ministro da Justiça (art. $100, \S 1^{\mathrm{o}}$ do Código Penal).

Dessa forma, a ação penal pública é a regra e a ação penal privada a exceção.

Quando o inquérito policial tiver início por requerimento do ofendido ou de quem tiver qualidade para representá-lo, deverá observar as disposições do art. $5^{\circ}, \S 1^{\circ}$ do Código de Processo Penal, ou seja, deverá ser narrado o fato com todas as suas circunstâncias, o suspeito deverá ser individualizado ou serão apontados os seus sinais característicos e as razões de convicção ou de presunção de ser ele o autor da infração, ou os motivos da impossibilidade de o fazer, sem prejuízo de serem arroladas as testemunhas, com indicação de sua profissão e residência. Esse requerimento do ofendido é denominado delatio criminis. No caso de requisição da autoridade judiciária ou do Ministério Público estas disposições também deverão ser observadas.

Em caso de infração de ação penal pública incondicionada, se a autoridade policial tomar conhecimento diretamente da ocorrência de crime tem ela dever de instaurar o inquérito policial, visto que o art. $5^{\circ}$ do Código de Processo Penal impõe que ele será iniciado. ${ }^{56}$

A primeira peça do inquérito, em caso de crime de ação penal pública, varia de acordo com a forma de seu início. Se decorrer de prisão em flagrante, o respectivo auto é a peça que inaugura o inquérito (art. 304 do Código de Processo Penal); se a autoridade policial tiver notícia diretamente do crime, não se tratando de hipótese de flagrante, a primeira peça do inquérito será a portaria, onde é registrada a ocorrência do crime, seu possível autor, o nome e qualificação da vítima e eventuais testemunhas, bem como outras circunstâncias relevantes; se decorrer de requisição da autoridade judiciária ou do Ministério Público ou de requerimento do ofendido ou de quem tiver qualidade para representá-lo, estas serão as peças inaugurais do inquérito policial.

Tourinho Filho coloca em discussão a possibilidade de indeferimento não só do requerimento do ofendido ou de seu representante, mas também da requisição do 
Ministério Público ou da autoridade judiciária. De forma resumida, sustenta ser possível indeferimento do requerimento do ofendido ou representante quando o fato for atípico, estiver extinta a punibilidade, o pedido não fornecer o mínimo necessário para o início das investigações ou for o requerente incapaz. Nestes casos, caberá recurso ao chefe da polícia (art. $5^{\circ}, \S 2^{\circ}$ do Código de Processo Penal). Se a autoridade não for competente para apreciar a representação, deverá remetê-la à autoridade que o for. ${ }^{57}$

Por outro lado, defende não poder a autoridade policial indeferir a requisição do Ministério Público ou da autoridade judiciária, sob o fundamento de haver distinção entre o requerimento do ofendido e a requisição no art. $5^{\circ}$, II e art. 13, II (nesta última hipótese, a autoridade deve realizar as diligências requisitadas pelo Ministério Público e pela autoridade judiciária) para concluir que o primeiro - requerimento - traduz solicitação, ao passo que o segundo - requisição - diz respeito a exigência legal, que não pode restar desatendida. ${ }^{58}$

Contudo, não encerra a discussão. Vai além e trata da hipótese de a requisição ser falha ao não fornecer dados suficientes que possibilitem a investigação ou ser o fato atípico. Apresenta como solução, na primeira hipótese, a expedição de ofício pela autoridade policial dirigida à autoridade requisitante mostrando-lhe a impossibilidade de proceder à investigação, solicitando-lhe outras informações e, na segunda hipótese, a menção no ofício da impossibilidade de cumprimento da ordem por ser ela manifestamente ilegal. Conclui que, em qualquer das hipóteses e desde que fornecidos os elementos faltantes para a persecução após a expedição do ofício dirigido à autoridade requisitante, não pode a autoridade policial desatender a requisição daquelas autoridades, sob pena de ser processada por desobediência, sem prejuízo de outras sanções disciplinares a que estará sujeita. ${ }^{59}$

Entretanto, a dúvida persiste se a autoridade requisitante, seja ela o Ministério Público ou a autoridade judiciária, persistir na ordem de instauração do inquérito policial sem fornecer os elementos faltantes ou não apresentar razões demonstrando ser o fato típico. O que deverá fazer a autoridade policial nestes casos? Poderá ela indeferir a

\footnotetext{
$57 \quad$ Ibidem, p. 121-122.

$58 \quad$ Ibidem, p. 121.

$59 \quad$ Ibidem, mesma página.
} 
requisição? Qual a medida que poderá tomar para evitar não só uma ação penal contra si pelo crime de desobediência, mas também para não instaurar o inquérito policial?

Dúvida não há de que não pode a autoridade policial indeferir a requisição do Ministério Público ou da autoridade judiciária. ${ }^{60}$ De fato, o art. $5^{\circ}, \S 2^{\circ}$ do Código de Processo Penal permite somente o indeferimento de requerimento de instauração de inquérito policial formulado pelo ofendido ou por quem tiver qualidade para representá-lo. $\mathrm{Na}$ falta de previsão legal admitindo o indeferimento da requisição, não poderá a autoridade policial fazê-lo, sob pena de incorrer no crime de desobediência (art. 330 do Código Penal).

Ademais, soaria estranho o Ministério Público, titular da ação penal pública (art. 129, I da Constituição Federal) e a autoridade judiciária, a quem compete o poder-dever de aplicar a lei ao caso concreto, definindo se determinado fato merece apuração e sanção, terem sua ordem indeferida pela autoridade policial. Não que esta autoridade seja hierarquicamente inferior àquelas, visto que entre elas não há esse tipo de vinculação funcional, mas porque essa situação seria um contrassenso em relação aos respectivos poderes que lhes foram outorgados pela lei e pela Constituição Federal.

Contudo, a despeito de não poder a autoridade policial indeferir a requisição dessas autoridades, não é correto ela sofrer processo por desobediência quando aquelas não trouxerem os elementos necessários para se proceder a investigação e persistir o Ministério Público, após receber ofício alertando esta situação, na instauração do inquérito, ou persistir a autoridade judiciária na ordem, quando for alertada pela autoridade policial e for evidente ser o fato atípico. E a razão é simples: a autoridade policial não está desobedecendo ordem legal, mas ordem ilegal. Ademais, se a autoridade policial atende a essa ordem ilegal, passará ela a ser a executora de tal ordem, não sendo justo que assuma a responsabilidade por ato que não deu causa, com todas as consequências que advirão por tal conduta. Aqui, o inquérito policial ainda não foi instaurado, de modo que não se pode falar em trancamento a pedido da autoridade policial dirigido à superior instância.

60 GRECO FILHO, Vicente. Manual de processo penal. $8^{\mathrm{a}}$ ed. rev. amp. atual. São Paulo: Saraiva, 2010, p. 80 . 
No entanto, deverá tomar alguma medida legal. A solução para tais hipóteses seria a autoridade policial, quando a requisição ilegal partir do Ministério Público, oficiar ao Procurador-Geral de Justiça, por analogia ao art. 28 do Código de Processo Penal, para solicitar o arquivamento da requisição. Caso o Procurador-Geral insista na abertura e seja evidente a ilegalidade de tal ato, como última medida, deverá impetrar habeas corpus preventivo, com pedido de liminar, para impedir a abertura de inquérito policial contra si por crime de desobediência, sob o fundamento de falta de justa causa (art. 648, I do Código de Processo Penal) e, ao mesmo tempo, impetrar mandado de segurança, com pedido de liminar, apontando a ilegalidade do ato do Ministério Público (art. 5o, LXIX da Constituição Federal e art. $1^{\circ}$ da Lei n. 12.016, de 7-8-2009). Se a ordem ilegal for do órgão do Ministério Público de $1^{\mathrm{o}}$ grau, o habeas corpus e o mandado de segurança deverão ser dirigidos ao tribunal respectivo - Tribunal de Justiça nos Estados ou Tribunal Regional Federal em caso de a autoridade requisitante ser Procurador da República -; se a ordem ilegal for do Procurador-Geral de Justiça, deverão ser dirigidos ao Tribunal de Justiça dos Estados.

No caso de requisição ilegal da autoridade judiciária, deverá tomar as mesmas medidas tomadas contra o ato do Ministério Público (e do Procurador-Geral em caso de insistência na instauração do inquérito policial), à exceção da utilização do art. 28 do Código de Processo Penal, eis que este dispositivo não se aplica, nem mesmo por analogia, ao Poder Judiciário, mas somente aos membros do Ministério Público.

Estudo interessante de Geraldo Batista de Siqueira sustenta que a requisição da abertura de inquérito policial pela autoridade judiciária ou do Ministério Público não vincula a autoridade policial, sob o fundamento de haver necessidade de esta última autoridade valorar a presença das condições da ação penal, tais como possibilidade jurídica do pedido e legitimidade de parte, para verificar a viabilidade da instauração do inquérito, dada a íntima relação entre o inquérito policial e a ação penal, visto que a ausência de tais condições tornaria inviável a ação penal e, em consequência, inútil o inquérito policial. ${ }^{61}$

Assim é que a investigação policial, na forma de inquérito policial, requer a presença de condições, as mesmas da ação penal, não sendo livre de exigências, eis que, se 
fosse livre sua abertura, não seria possível, em consequência, seu trancamento. Portanto, o objeto da investigação deve se amoldar à possibilidade jurídica do pedido, com tipicidade e ausência de causa de extinção da punibilidade, assim como legitimidade de parte, visto que, caso o fato seja, por exemplo, atípico, a instauração do inquérito policial, ainda que diante de requisição ministerial ou judicial, ocorreria em evidente ilegalidade, sendo possível seu trancamento por habeas corpus. ${ }^{62}$

Superada a questão da impossibilidade de indeferimento da requisição, resta analisar qual o recurso cabível contra o indeferimento do requerimento do ofendido ou de quem tenha qualidade para representá-lo, seu prazo, forma e autoridade competente para analisá-lo.

$\mathrm{O}$ art. $5^{\circ}, \S 2^{\circ}$ do Código de Processo Penal não esclarece essas circunstâncias. Porém, a expressão chefe de polícia, a quem compete analisar o recurso contra a decisão de indeferimento de instauração de inquérito policial, deve ser interpretada à luz da lei orgânica da polícia civil de cada Estado ou da polícia federal (art. 144, $\S 7^{\circ}$ da Constituição Federal), onde está estruturada a organização, funcionamento e hierarquia administrativa de tais órgãos.

O recurso cabível contra o indeferimento e dirigido ao chefe de polícia, tendo em vista que o inquérito policial é um conjunto de atos, será um recurso administrativo, portanto, sem natureza jurídica de recurso judicial. Assim, trata-se de recurso administrativo inominado. Além disso, sua decisão não faz coisa julgada, eis que os órgãos das polícias não exercem jurisdição, razão pela qual pode ser renovado. Quanto ao prazo, pode ser interposto enquanto não estiver extinta a punibilidade. ${ }^{63}$ Também não há forma definida, embora seja recomendável o uso da forma escrita, visto que todas as ocorrências do inquérito policial são reduzidas a escrito. Ademais, se o requerimento de instauração do inquérito policial exige a observância dos requisitos previstos no art. $5^{\circ}, \S 1^{\circ}$ do Código de Processo Penal, que será formulado na forma escrita, não há razão para que o respectivo recurso contra o indeferimento de instauração do inquérito policial assim não o seja.

\footnotetext{
Ibidem, p. 43.

63 TOURINHO FILHO, Fernando da Costa. Manual de processo penal. 14 a ed. São Paulo: Saraiva, 2011, p. 122.
} 
Ainda em caso de crime de ação penal pública incondicionada, o inquérito policial pode ser iniciado pela autoridade policial quando houver comunicação de qualquer pessoa do povo, verbalmente ou por escrito, dando conta da existência de infração penal e aquela, verificando a procedência das informações, mandará instaurá-lo (art. $5^{\circ}, \S 3^{\circ}$ do Código de Processo Penal).

Algumas observações são importantes sobre essa forma de início do inquérito policial. Em primeiro lugar, ela só tem cabimento nos crimes de ação penal pública incondicionada, visto que se for caso de ação penal pública condicionada à representação do ofendido ou de requisição do Ministro da Justiça, ou de hipótese de ação privada, somente se dá início ao inquérito com a apresentação da representação ou mediante o pedido do ofendido ou representante (art. $5^{\circ}, \S \S 4^{\circ}$ e $5^{\circ}$ do Código de Processo Penal e artigo $100, \S 1^{\circ}$, segunda parte e $\S 2^{\circ}$ do Código Penal).

Trata-se de uma faculdade da pessoa que tiver conhecimento da existência de infração penal, eis que o dispositivo dispõe que ela poderá comunicar a autoridade. Se não fizer a comunicação não fica sujeita a qualquer sanção.

A comunicação à autoridade será feita verbalmente ou por escrito. Mas uma vez feita a comunicação, a pessoa deverá se identificar, não se admitindo a denúncia anônima. ${ }^{64}$

Verificando a procedência das informações, a autoridade policial está obrigada a instaurar o inquérito policial. As razões são evidentes. A lei fala que nessa hipótese a autoridade mandará instaurá-lo, dando a clara noção de ser imperativa a disposição. Por outro lado, se a autoridade policial não pode mandar arquivar inquérito policial (art. 17 do Código de Processo Penal), dada a indisponibilidade de seu prosseguimento, razão maior há para não ficar ao seu alvedrio a abertura de inquérito para apurar crime de ação penal pública incondicionada.

Por outro lado, a conduta de quem provocar a ação de autoridade, comunicando-lhe a ocorrência de crime ou contravenção que sabe não ter se verificado está prevista no Código Penal em seu art. 340, com pena de detenção de um a seis meses ou multa. 
Como já dito alhures, o inquérito policial, nos crimes em que a ação penal pública depender de representação, sem ela não poderá ser iniciado (art. $5^{\circ}, \S 4^{\circ}$ do Código de Processo Penal).

A representação é a manifestação do ofendido ou de quem tiver qualidade para representá-lo informando a autoridade policial que deseja o início da persecução penal e que não se opõe à instauração do inquérito policial. Se ocorrer a morte do ofendido ou ele for declarado ausente por decisão judicial, a representação poderá ser formulada pelo cônjuge, ascendente, descendente ou irmão (art. 24, $\S 1^{\circ}$ do Código de Processo Penal). O prazo para sua apresentação é de seis meses contados da data em que o ofendido ou seu representante souber quem é o autor do fato ou, no caso de morte do ofendido ou de declaração judicial de sua ausência, de tais datas para o cônjuge, ascendente, descendente ou irmão (art. 24, $\S 1^{\circ}$ e art. 38 do Código de Processo Penal). A representação independe de assistência de advogado. ${ }^{65}$

Ao invés da denominada representação do ofendido ou de seu representante legal, há outra hipótese de início do inquérito policial em caso de ação penal pública condicionada: por requisição do Ministro da Justiça.

É o caso de ocorrência de crime contra a honra praticado contra o Presidente da República ou contra chefe de governo estrangeiro (art. 145, parágrafo único, primeira parte do Código Penal). Além dessa hipótese, também é necessária a requisição do Ministro da Justiça para a instauração do inquérito policial quando ocorrer crime cometido por estrangeiro contra brasileiro fora do Brasil, respeitadas algumas condições (art. $7^{\circ}, \S \S 2^{\circ} \mathrm{e}$ $3^{\circ}$ do Código Penal).

65 SILVA, Luiz Cláudio; SILVA, Franklyn Roger Alves. Manual de processo e prática penal. $4^{\text {a }}$ ed. rev. amp. atual. Rio de Janeiro: Forense, 2010, p. 387. 
Vencidos os aspectos relativos ao início do inquérito policial nos crimes de ação pública, incondicionada ou condicionada, resta analisar seu início nos crimes de ação privada.

\subsubsection{Crimes de ação penal privada}

Nos crimes de ação penal privada, a autoridade policial somente poderá proceder a inquérito a requerimento de quem tenha qualidade para intentá-la ( $\operatorname{art.} 5^{\circ}, \S 5^{\circ}$ do Código de Processo Penal), ou seja, o ofendido ou quem tenha qualidade para representá-lo (artigo 30 do Código de Processo Penal).

Se o ofendido morrer ou for judicialmente declarado ausente, o direito de promover ação privada ou nela prosseguir passa ao cônjuge, ascendente, descendente ou irmão (art. 31 do Código de Processo Penal), razão pela qual a autoridade policial não poderá instaurar inquérito penal sem requerimento dessas pessoas.

Por outro lado, o requerimento de abertura de inquérito policial deve conter os elementos do art. $5^{\circ}, \S 1^{\circ}$ do Código de Processo Penal. Além disso, extrai-se do art. 38 do Código de Processo Penal que a ação penal privada deve ser intentada dentro do prazo de seis meses, contados do dia em que o ofendido ou representante souber quem cometeu o crime, o que implica na necessidade de o requerimento ser formulado dentro de tal prazo e de modo que seja possível a conclusão do inquérito dentro dele para que possa a ação penal ser ajuizada antes de seu término. Há quem entenda, todavia, que este requerimento pode ser formulado verbalmente. ${ }^{66}$

Se o ofendido for menor de 18 anos ou mentalmente enfermo ou retardado mental, compete a seu representante legal formular o requerimento de instauração do inquérito policial. Se não tiver representante legal, ou se colidirem os interesses deste com os daquele, o requerimento será formulado por curador especial nomeado pelo juiz competente para a ação penal (art. 33 do Código de Processo Penal). 
Está implicitamente revogado o art. 34 do Código de Processo Penal que previa que se o ofendido fosse maior de 18 anos e menor de 21, o direito de queixa, e por consequência, o direito de requerer instauração de inquérito policial nos crimes de ação penal privada, poderia ser exercido por qualquer deles, visto que o Código Civil de 2002 (Lei n. 10.406, de 10-1-2002) dispôs que a maioridade se alcança ao se completar 18 anos (art. $5^{\circ}$ ), razão pela qual somente a ele maior de 18 anos é possível requerer sua instauração, salvo, é evidente, se for mentalmente enfermo ou retardado mental. Aliás, também não se nomeia mais curador ao indiciado menor de 21 anos e maior de 18 pelas mesmas razões (art. 15 do Código de Processo Penal).

A restrição que havia no art. 35 do Código de Processo Penal para a mulher casada propor queixa e, em consequência, requerer instauração de inquérito nos crimes de ação penal privada, foi revogada pela Lei n. 9.520, de 27-11-1997.

Pode ser indeferido o requerimento de instauração do inquérito nos crimes de ação penal privada pela autoridade policial? Sim, com fundamento no art. $5^{\circ}, \S 2^{\circ}$ do Código de Processo Penal, por analogia. Poderá o interessado, nesse caso, apresentar recurso administrativo ao chefe de polícia, mas desde que dentro do prazo de seis meses previsto no art. 38 do mesmo estatuto.

É possível, ainda, ser intentada a ação penal privada subsidiária da pública, quando o Ministério Público não oferece a denúncia no prazo legal (art. 29 do Código de Processo Penal e art. 100, $\S 3^{\circ}$ do Código Penal).

\subsection{Conclusão do inquérito}

Se a finalidade do inquérito policial é servir de instrumento para a propositura da ação penal após a apuração da autoria e da materialidade da infração penal, com apuração desses elementos deve a autoridade policial que o preside concluí-lo. Contudo, a lei fixa prazos para sua conclusão com o intuito de solucionar as infrações penais no menor prazo possível, possibilitando o titular da ação penal ajuizar o pedido se os elementos colhidos durante sua tramitação apontarem a ocorrência da infração penal e indicarem seu autor. 
De um modo geral, o inquérito policial deve ser concluído no prazo de 30 dias se o indiciado estiver solto e em 10 dias se estiver preso (art. 10 do Código de Processo Penal). Esses prazos servem para os inquéritos policiais de competência das polícias civis, visto que nas infrações penais que devem ser apuradas pela polícia federal, dada a competência da justiça federal para seu processamento e julgamento, o prazo para a conclusão do inquérito, estando o indiciado preso, é de 15 dias, prorrogáveis por mais 15 dias a pedido da autoridade policial e deferido pelo juiz competente para o conhecimento do processo (art. 66 da Lei n. 5.010, de 30-5-1966).

No caso de o indiciado estar solto, pode haver prorrogação do prazo de conclusão do inquérito quando o fato for de difícil elucidação, a pedido da autoridade policial e deferido pelo juiz (art. 10, $\S 3^{\circ}$ do Código de Processo Penal). Ao contrário, na hipótese de réu preso, o prazo não pode ser prorrogado. Não sendo concluído o inquérito policial no prazo legal em caso de indiciado preso, pode ser impetrada ordem de habeas corpus em seu favor, com fundamento do art. 648, II, do Código de Processo Penal. ${ }^{67}$

Na hipótese de apuração de crime contra a economia popular, o prazo para a conclusão do inquérito policial é de 10 dias, tanto para o indiciado preso quanto para o solto (art. 10, $\S 1^{\circ}$ da Lei n. 1.521, de 26-12-1951).

Por sua vez, na hipótese de inquérito policial instaurado para apuração de infrações penais ligadas a entorpecentes, o prazo para sua conclusão é de 30 dias caso esteja o indiciado preso e de 90 dias no caso de estar solto (art. 51 da Lei n. 11.343, de 23-8-2006), podendo haver duplicação desses prazos pelo juiz, mediante pedido justificado da autoridade policial e após ouvido o Ministério Público (art. 51, parágrafo único, da Lei n. 11.343, de 23-8-2006).

Concluindo a autoridade policial as diligências necessárias para a apuração da materialidade e autoria da infração penal, deverá elaborar relatório apontando tudo o que 
foi apurado durante as investigações. Ainda no relatório, poderá indicar as testemunhas que por algum motivo não tenham ainda sido ouvidas, mencionando o lugar onde possam ser encontradas (art. $10, \S \S 1^{\circ}$ e $2^{\circ}$ do Código de Processo Penal).

No relatório, a autoridade policial não deve fazer qualquer juízo de valor. Deve se limitar a apontar tudo o que foi apurado durante as investigações. Se, embora indevidamente, apresentar qualquer apreciação subjetiva sobra a culpabilidade ou antijuridicidade, haverá mera irregularidade, sem nenhuma consequência. ${ }^{68}$

A despeito disso, pode a autoridade policial, no relatório, apresentar representação para a decretação de prisão preventiva (art. 311 do Código de Processo Penal, na redação que lhe foi dada pela Lei n. 12.403, de 4-5-2011), que será analisada pelo Ministério Público e pelo juiz ${ }^{69}$, ou mesmo da prisão temporária (art. $2^{\circ}$ da Lei n. 7.960, de 21-121989).

Além disso, pode a autoridade policial, no relatório, tipificar a conduta, ou seja, qualificar o ato praticado pelo indiciado dentro do ordenamento penal, apontando em qual dispositivo legal ele incorreu, embora essa tipificação não vincule o Ministério Público. ${ }^{70}$

De outro lado, a ausência de relatório é mera irregularidade e não afeta a ação penal. $^{71}$

Elaborado o relatório, que é a última peça do inquérito policial, ele será remetido ao juízo competente com os instrumentos do crime e os objetos que interessarem à prova (art. 11 do Código de Processo Penal).

1.11 Situações do inquérito ao ser encaminhado a juízo

\footnotetext{
$68 \quad$ Ibidem, p. 151.

69 GRECO FILHO, Vicente. Manual de processo penal. $8^{\mathrm{a}}$ ed. rev. amp. atual. São Paulo: Saraiva, 2010, p. 81.

CARVALHO, Djalma Eutímio de. Curso de processo penal. $2^{\mathrm{a}}$ ed. rev. atual. Rio de Janeiro: Forense, 2009, p. 53.

71 Ibidem, mesma página.
} 
Como dito no item anterior, uma vez elaborado o relatório da autoridade que presidiu o inquérito policial, será ele remetido a juízo com os instrumentos do crime e os objetos que interessarem à prova (art. 11 do Código de Processo Penal).

Uma vez chegando a juízo, dependendo da comarca e da lei de organização judiciária de cada Estado, será ele distribuído a um dos ofícios judiciais, salvo na hipótese de prevenção, quando será remetido ao ofício judicial prevento, à vara especializada ou mesmo à vara única.

Distribuído o inquérito, será ele remetido ao Ministério Público. Há Estados onde há previsão regimental determinando o encaminhamento do inquérito diretamente ao Ministério Público, sem despacho do juiz, eis que este nada deve fazer nesse momento. ${ }^{72}$

Encaminhado o inquérito policial ao Ministério Público após a distribuição a um dos ofícios judiciais, com ou sem despacho judicial, poderá o órgão ministerial tomar várias alternativas.

A primeira das alternativas é o retorno do inquérito policial para efetuar novas diligências com o fim de esclarecer pontos ainda obscuros ou a complementação de diligências necessárias para melhor adequação da conduta do indiciado. É a hipótese, por exemplo, de não ter restado claro pelas investigações se o indiciado agiu sozinho ao cometer um suposto crime de furto ou em concurso de agentes com um ou mais de um comparsa. Esse esclarecimento é de suma importância, visto que influenciará na qualificação jurídica da conduta do indiciado, eis que poderá ser denunciado por furto simples (art. 155, caput do Código Penal) na hipótese de ser informado no inquérito após sua devolução à polícia judiciária que cometeu o crime sozinho, ou por furto qualificado pelo concurso de agentes (art. 155, $\S 4^{\circ}$, IV do Código Penal) no caso de esclarecer a autoridade policial após o retorno do inquérito que o indiciado agiu com uma ou mais pessoas.

Além desse ponto obscuro esclarecido com o retorno do inquérito à polícia judiciária, é possível que não tenha sido realizada diligência necessária para melhor 
adequação da conduta do indiciado. Isso ocorre quando a autoridade policial deixou de realizar, utilizando mais uma vez a hipótese do crime de furto, perícia na porta de um imóvel para informar se houve arrombamento para a subtração da coisa, o que também influenciará na qualificação jurídica da conduta do indiciado, que poderá ser processado por furto simples (art. 155, caput do Código Penal) se restar esclarecido após a devolução do inquérito à polícia judiciária que o imóvel onde ocorreu a subtração estava com as portas abertas, ou por furto qualificado pela destruição ou rompimento de obstáculo à subtração da coisa (art. 155, $\S 4^{\circ}$, I do Código Penal) se a perícia constatar tal circunstância.

Duas observações são importantes dentro dessa primeira alternativa aberta ao Ministério Público de entender necessário o retorno do inquérito policial para novas diligências: o juiz não pode indeferir esse retorno do inquérito solicitado pelo Ministério Público - e se o fizer a decisão pode ser revista por correição parcial - e o retorno à polícia do inquérito só é possível se o indiciado estiver solto, visto que se estiver preso e houver necessidade de novos esclarecimentos ainda não há base para a denúncia ${ }^{73}$ e sua manutenção no cárcere será considerada coação ilegal, passível de correção via habeas corpus (art. 647 e art. 648, II, do Código de Processo Penal). O que é possível é o retorno do inquérito para esclarecimentos com o relaxamento concomitante da prisão do investigado, dada a ilegalidade de sua manutenção (art. 5', LXV da Constituição Federal), ou o oferecimento da denúncia, sem devolução do inquérito à polícia judiciária, visto que a ela serve de base, com realização de diligências complementares em separado. ${ }^{74}$

A segunda alternativa que se abre ao Ministério Público ao receber o inquérito policial é requerer seu encaminhamento a outro juízo para que possa ser oferecida denúncia pelo órgão do Ministério Público daquele juízo (ou foro), uma vez que entende não ser sua atribuição oferecer a denúncia relativa àquele inquérito. ${ }^{75}$

Se remetido o inquérito policial ao outro juízo para distribuição e encaminhados os autos ao Ministério Público, este poderá entender que o anterior órgão do Ministério Público era competente para oferecer a denúncia e, por conta disso, suscitar o conflito de atribuições para que a denúncia seja oferecida pelo órgão do Ministério Público daquela

\begin{tabular}{lr}
\hline 73 & Ibidem, p. 86. \\
74 & Ibidem, mesma página. \\
75 & Ibidem, mesma página.
\end{tabular}


comarca. Aqui não se fala em competência jurisdicional, mas em conflito de atribuições porque a denúncia ainda não foi oferecida, ou seja, o conflito ocorre entre órgãos do Ministério Público e não entre autoridades judiciárias.

Esse conflito, dependendo da lei orgânica do Ministério Público de cada Estado, é decidido pelo Procurador-Geral de Justiça ou pelo Conselho Superior do Ministério Público. No âmbito federal, o conflito de atribuições ocorre entre procuradores da República e será decidido pelas Câmaras de Coordenação e Revisão (Lei Complementar n. 75, de 20-5-1993, art. 62, VII).

Por outro lado, a decisão do juiz que determinou o encaminhamento solicitado pelo Ministério Público é meramente administrativa e não tem o condão de fixar competência jurisdicional $^{76}$, de modo que com o recebimento do inquérito policial pelo outro juízo, uma vez que ainda não foi oferecida denúncia, não pode o juiz da nova comarca suscitar conflito de competência, já que se trata de encaminhamento de inquérito policial e não de processo judicial e a remessa se deu a pedido do Ministério Público e não do juiz ao qual o inquérito foi originalmente distribuído.

Partindo para a terceira possibilidade que surge ao Ministério Público ao receber o inquérito policial distribuído, entendendo ele que seus elementos não permitem a propositura da ação penal, poderá requerer seu arquivamento, fundamentando seu pedido.

Essa terceira possibilidade - arquivamento - será analisada de forma mais detalhada no item 1.12 .

A outra alternativa do Ministério Público ao receber autos de inquérito policial, verificando que nele se apurou crime de ação penal de iniciativa privada, é solicitar que se aguarde a iniciativa do ofendido até que ocorra a decadência, se não for apresentada a queixa no prazo legal. ${ }^{77}$

$76 \quad$ Ibidem, mesma página.
$77 \quad$ Ibidem, p. 88. 
Por fim, a última alternativa que é dada ao Ministério Público é oferecer a denúncia, fundamentando-se nos elementos colhidos durante a tramitação do inquérito policial se este tiver apurado satisfatoriamente a autoria e a materialidade do delito.

Se o indiciado estiver preso, deverá oferecer a denúncia no prazo de cinco dias; se estiver solto, no prazo de quinze dias (art. 46 do Código de Processo Penal).

Se o indiciado estiver preso e a denúncia não for oferecida no prazo de cinco dias, deverá ser colocado imediatamente em liberdade (art. 5, LXV da Constituição Federal), mas a não observância desse prazo não impede a propositura da ação penal, inclusive a ação penal privada subsidiária da pública pelo ofendido ou por quem tenha qualidade para representá-lo (art. 29 do Código de Processo Penal), mas poderá acarretar sanção de ordem disciplinar ao membro do Ministério Público que não agiu dentro do prazo se ficar comprovada desídia ou má-fé. O único obstáculo à propositura da ação penal após o prazo legal seria a ocorrência de prescrição (art. 107, IV do Código Penal).

\subsection{Diferença entre arquivamento e trancamento do inquérito policial}

A finalidade do inquérito policial, conforme dito no item 1.3, é servir de instrumento para a propositura da ação penal pelo Ministério Público, nos casos de ação penal pública, ou ao ofendido, nas hipóteses de ação penal privada.

Também restou esclarecido no item 1.10, que a autoridade policial que presidiu o inquérito e elaborou o relatório antes de seu envio ao juízo competente com os instrumentos do crime e os objetos que interessarem à prova (art. $10, \S 1^{\circ}$ e art. 11 do Código de Processo Penal) não pode emitir juízo de valor nessa peça, eis que a ela somente compete apurar os fatos, verificando a ocorrência da autoria e materialidade, com todas as suas circunstâncias a fim de cumprir seu encargo. E isso ocorre porque cabe ao Ministério Público, na ação penal pública, com base nos elementos colhidos durante o inquérito policial, analisar se as provas colhidas durante a investigação autorizam sua propositura. Ou seja, ao Ministério Público compete a opinio delicti, a formação de juízo de valor com base nos elementos colhidos a fim de averiguar se é caso de propor a ação penal. Em razão disso, não pode a autoridade policial arquivar autos de inquérito policial (art. 17 do Código 
de Processo Penal). Essa proibição retrata o princípio da indisponibilidade do inquérito pela autoridade policial. ${ }^{78}$

Se o Ministério Público entender que é caso de propor a ação penal pública, assim o fará. Caso contrário, pedirá o arquivamento dos autos do inquérito policial ao juiz competente. Este, por sua vez, se sustentar o mesmo entendimento do Ministério Público, mandará arquivar o inquérito. Caso contrário, não concordando com as razões apresentadas pelo órgão do Ministério Público de primeiro grau, remeterá os autos ao Procurador-Geral de Justiça - ou às Câmaras de Coordenação e Revisão na hipótese de promoção de arquivamento formulada pelo Ministério Público Federal (Lei Complementar 75, de 20-51993, art. 62, IV) - para que seja tomada uma das seguintes providências: oferecimento da denúncia, designação de outro órgão do Ministério Público para oferecê-la, ou insistência no pedido de arquivamento, ao qual só então estará o juiz obrigado a atender (art. 28 do Código de Processo Penal).

Greco Filho aponta uma quarta possibilidade que tem o Procurador-Geral de Justiça, qual seja, determinar diligências complementares e que serão requisitadas diretamente à polícia, para poder decidir qual a alternativa que vai tomar. ${ }^{79}$

Pode o promotor - ou procurador da República - designado pelo órgão superior do Ministério Público discordar e não oferecer denúncia? Não. Como órgão hierarquicamente superior, o Procurador-Geral ou a Câmara de Coordenação e Revisão decidiu por ser oferecida denúncia e esta terá de ser formulada. Ao órgão de primeiro grau restará, se o caso, apresentar razões pessoais para solicitar a designação de outro membro da instituição para oferecer a denúncia; caso contrário, terá de fazê-lo sob pena de aplicação de sanção de natureza disciplinar.

A conduta autorizada ao juiz pelo art. 28 do Código de Processo Penal seria uma forma de ser feito por ele o controle da observância do princípio da obrigatoriedade da ação penal. No entanto, entendemos que se trata de função anômala, visto que o titular da ação penal é o Ministério Público (art. 129, I, da Constituição Federal) e a ele compete,

\footnotetext{
78 SILVA, Luiz Cláudio; SILVA, Franklyn Roger Alves. Manual de processo e prática penal. $4^{\text {a }}$ ed. rev. amp. atual. Rio de Janeiro: Forense, 2010, p. 389.

GRECO FILHO, Vicente. Manual de processo penal. $8^{\text {a }}$ ed. rev. amp. atual. São Paulo: Saraiva, 2010, p. 87.
} 
com fundamento nos elementos colhidos durante a investigação e sua confrontação com o ordenamento jurídico, decidir se é caso de propositura da ação penal ou de arquivamento. Ademais, o processo penal moderno é um processo de partes, onde cada sujeito processual deve decidir, sempre apresentando os respectivos fundamentos, qual a melhor conduta que deseja seguir. Por isso, seria melhor que o legislador determinasse que a autoridade policial encaminhasse o inquérito policial diretamente ao Ministério Público e a esse competisse a decisão de arquivamento, sem necessidade de controle jurisdicional.

Por outro lado, o princípio acusatório não permite ao juiz decidir se é caso de arquivamento ou não, visto que sua atuação como órgão acusador pode comprometer sua imparcialidade. Foi essa a razão para o sistema brasileiro instituir órgãos diversos para acusar e julgar.

Esse problema seria resolvido pelo Projeto de novo Código de Processo Penal que virou o Projeto de Lei n. 4.209/2001 do Congresso Nacional - não convertido em lei - visto que a promoção de arquivamento competiria com exclusividade ao Ministério Público (art. 28 do Projeto), sem qualquer intervenção do Poder Judiciário.

Deveria o membro do Ministério Público fundamentar o arquivamento e remeter cópias de tal pronunciamento, em três dias, a órgão superior do Ministério Público, sendo intimados, no mesmo prazo, mediante carta registrada e com aviso de retorno, o investigado (ou indiciado), o ofendido ou quem tenha qualidade para representá-lo (art. 28, $\S 1^{\circ}$ do Projeto), que poderiam apresentar razões escritas ao órgão superior até a data designada para a deliberação de confirmação ou não do arquivamento. ${ }^{80}$ Caso fosse confirmado o arquivamento pelo órgão superior do Ministério Público, os autos deveriam ser encaminhados ao juízo competente para que fosse efetuado o arquivamento e declarada a cessação de medidas cautelares eventualmente concedidas (art. $28, \S 6^{\circ}$ do Projeto).

De qualquer modo, e se houver, no sistema atual, mais de um investigado e o Ministério Público entender que contra um deles não há indícios a sustentar a propositura da ação penal e contra o outro carece o inquérito policial de mais esclarecimentos? Nessa hipótese, deve o Ministério Público requerer ao juiz a exclusão dos investigados contra os $80 \quad$ TUCCI, Rogério Lauria. Investigação criminal no projeto de reforma do código de processo penal. Revista do Advogado. São Paulo: Associação dos Advogados de São Paulo, ano XXIV, $\mathrm{n}^{\circ}$ 78, p. 103-110, set. 2004. 
quais não há elementos suficientes para o ajuizamento da ação penal e o retorno do inquérito policial à repartição policial para o prosseguimento das investigações e esclarecimentos faltantes quanto aos demais. ${ }^{81}$

Por outro lado, contra a decisão que determina o arquivamento do inquérito policial não cabe recurso. ${ }^{82}$

No caso de um órgão do Ministério Público requerer o arquivamento do inquérito policial, não pode outro membro da instituição denunciar o imputado, sem cumprimento do disposto no art. 28 do Código de Processo Penal, tendo em vista que se assim atuar estará violando o princípio do promotor natural. ${ }^{83}$

Situação interessante é citada por Eutímio de Carvalho: o que ocorre nas infrações penais de competência originária dos tribunais em decorrência de foro privilegiado por prerrogativa de função se o Procurador-Geral requerer o arquivamento do inquérito policial? Assim como ocorre em primeiro grau, não pode o órgão julgador discordar desse arquivamento e não se cumpre o disposto no art. 28 do Código de Processo Penal, uma vez que não há órgão superior do Ministério Público no Estado para revisar o pedido de arquivamento formulado pelo Procurador-Geral. Porém, poderá o ofendido requerer a revisão do pedido de arquivamento formulado pelo Procurador-Geral, endereçando seu pedido ao Colégio de Procuradores de Justiça, com fundamento no art. 12, XI da Lei n. 8.625, de 12-2-1993 (Lei Orgânica Nacional do Ministério Público). Antes da apreciação desse órgão, o próprio Procurador-Geral poderá apreciar esse requerimento, retratando-se. Caso não se retrate, encaminhará o pedido ao Colégio de Procuradores, que poderá manter a decisão do Procurador-Geral ou, se o acatar, designar substituto legal para denunciar o imputado. $^{84}$

Na hipótese de ação penal privada, da mesma forma, não cabe à autoridade policial mandar arquivar autos de inquérito policial instaurado a pedido do ofendido ou de seu representante (art. 17 do Código de Processo Penal). Concluído o inquérito e formulado o

\footnotetext{
$81 \quad$ SILVA, Luiz Cláudio; SILVA, Franklyn Roger Alves. Manual de processo e prática penal. $4^{\text {a }}$ ed. rev. amp. atual. Rio de Janeiro: Forense, 2010, p. 398-399. Ibidem, p. 389.

CARVALHO, Djalma Eutímio de. Curso de processo penal. $2^{\mathrm{a}}$ ed. rev. atual. Rio de Janeiro: Forense, 2009, p. 54.

${ }^{84}$ Ibidem, mesma página.
} 
relatório, deverá ser remetido a juízo para aguardar a eventual propositura da ação penal privada pelo ofendido ou representante, ou mesmo será a eles entregue, por traslado para, se quiserem, oferecer a queixa. ${ }^{85}$ Como o direito de queixa decai no prazo de seis meses contados da data em que o ofendido ou seu representante souber quem é o autor do fato (art. 38 do Código de Processo Penal), se qualquer deles não propuser a ação penal, estará extinta a punibilidade, que deverá ser declarada pelo juiz, com fundamento no art. 107, IV do Código Penal, arquivando-se o inquérito.

Se houver pedido de arquivamento do inquérito pela pessoa habilitada a propor a ação penal privada, sendo este requerimento dirigido ao juiz competente, a conduta importa em renúncia ao direito de queixa (art. 49 do Código de Processo Penal) e o fundamento da extinção da punibilidade a ser decretada pelo juiz passa a ser o art. 107, V do Código Penal, acarretando o arquivamento do inquérito. ${ }^{86}$

$\mathrm{O}$ arquivamento decorre do encerramento normal das investigações sem a respectiva propositura da ação penal por seu titular, seja ele o Ministério Público, em caso de ação penal pública, seja o particular, em caso de ação penal privada.

Esse encerramento, seja qual for a razão, não tem o mesmo significado de trancamento.

Como dito acima, o trancamento é o encerramento prematuro do inquérito policial. Nele, como veremos, a causa do encerramento é a falta de justa causa do próprio inquérito policial, o que não se confunde com a falta de justa causa para a ação penal, embora possa haver correlação entre a justa causa para o inquérito e justa causa para a ação penal. É decretado o fim do inquérito antes mesmo de sua conclusão, mesmo antes de eventual elaboração do relatório pela autoridade policial.

É verdade que as causas, eventualmente, do arquivamento e do trancamento podem coincidir. Por exemplo, ao final das investigações e já concluído o inquérito, com relatório da autoridade policial, pode ser que o dominus litis entenda que restou comprovado que o

\footnotetext{
85 SILVA, Luiz Cláudio; SILVA, Franklyn Roger Alves. Manual de processo e prática penal. $4^{\text {a }}$ ed. rev. amp. atual. Rio de Janeiro: Forense, 2010, p. 390.

TOURINHO FILHO, Fernando da Costa. Manual de processo penal. $14^{\mathrm{a}}$ ed. São Paulo: Saraiva, 2011, p. 152.
} 
indiciado não foi o autor do delito investigado. Nesse caso, o Ministério Público, no caso de ação penal pública, requer o arquivamento com fundamento no art. 18 do Código de Processo Penal e o juiz acolhe tais fundamentos para arquivar o inquérito.

O trancamento pode ter a mesma causa, no caso, ficar comprovado que o investigado não foi o autor do crime apurado. Ocorre que a forma e a época como o inquérito chega ao seu fim, em caso de trancamento é diversa. Nessa hipótese, é possível que já no início das investigações, ou ainda mesmo antes da elaboração do relatório pela autoridade policial, seja decretado seu trancamento, ou seja, seu encerramento prematuro, se o investigado o requerer, seja por meio do habeas corpus, seja por mera petição - como veremos adiante - demonstrando não ser o autor do fato, o que afasta a justa causa para seu prosseguimento.

Ademais, o arquivamento do inquérito policial é determinado pela autoridade judiciária com fundamento no art. 18 do Código de Processo Penal e a pedido do Ministério Público - na ação penal pública -, nos próprios autos, ao passo que o trancamento é requerido pelo indiciado ou por quem o represente, também nos próprios autos por mera petição ou por meio de habeas corpus e com fundamento na falta de justa causa a acarretar o constrangimento ilegal sofrido pelo paciente (art. 648, I, do Código de Processo Penal), cujo processamento e julgamento ocorrerão em autos distintos.

Assim, entendemos que arquivamento e trancamento do inquérito policial são coisas distintas, de modo que o uso do termo trancamento, para nós, é o mais apropriado.

\subsection{3}

\section{Arquivamento implícito do inquérito}

$\mathrm{O}$ arquivamento implícito do inquérito policial ocorre quando, na ação penal pública, o Ministério Público deixa de incluir na denúncia um dos investigados ou um dos delitos apurados na fase investigativa, sem se manifestar expressamente pelo arquivamento a favor de um dos envolvidos ou pela exclusão de um dos delitos e não ocorre, por parte do 
magistrado que recebe a denúncia, a providência prevista no art. 28 do Código de Processo Penal. Também pode ser denominado arquivamento tácito ${ }^{87}$.

$\mathrm{O}$ arquivamento do inquérito sempre deve ser requerido pelo Ministério Público de forma expressa e fundamentada a fim de fazer valer o princípio da indivisibilidade da ação penal quando for hipótese de não inclusão de um dos investigados na denúncia. Se não o fizer, deverá o juiz remeter os autos ao Ministério Público para aditar a denúncia, podendo este órgão, ao invés de aditá-la, requerer o arquivamento expresso do inquérito contra um dos investigados se não houver elementos para a propositura da ação penal contra um deles. ${ }^{88}$ Nessa hipótese, pode o juiz determinar o cumprimento da providência prevista no art. 28 do Código de Processo Penal, remetendo a decisão sobre o arquivamento agora explícito ao Procurador-Geral de Justiça.

A mesma providência deve tomar o juiz quando o Ministério Público não incluir um dos delitos apurados durante a tramitação do inquérito policial, sem se manifestar expressamente porque assim agiu, só que aqui o juiz estará primando pelo princípio da obrigatoriedade da ação penal. ${ }^{89}$

Mas, e se ocorrer de o juiz não perceber a omissão do Ministério Público e prosseguir na ação penal, recebendo a denúncia contra apenas um dos investigados ou por apenas um dos delitos apurados? Poderá haver denúncia posterior contra o outro investigado ou para punir delito arquivado implicitamente, ainda que já haja sentença transitada em julgado com relação aos investigados ou crimes incluídos na denúncia? A resposta é afirmativa, desde que não tenha ocorrido a prescrição da pretensão punitiva durante o período do arquivamento implícito. Além disso, não se trata de hipótese de descumprimento da Súmula 524 do Supremo Tribunal Federal, ou seja, não é caso de desarquivamento sem novas provas, visto que o arquivamento não ocorreu de forma expressa e, portanto, não poderia ter ocorrido. ${ }^{90}$

\footnotetext{
87 JARDIM, Afrânio Silva. Arquivamento e desarquivamento do inquérito policial. Revista de Processo. São Paulo: Revista dos Tribunais, ano IX, nº 35, p. 264-276, abr./jun. 1984. penal. $4^{\text {a }}$ ed. rev. amp. atual. Rio de Janeiro: Forense, 2010, p. 399.

89 Ibidem, mesma página.

$90 \quad$ Ibidem, p. 400.
} 
A decisão que determina o arquivamento do inquérito policial, salvo algumas hipóteses, não faz coisa julgada material. Com isso, após arquivado o inquérito policial, se a autoridade policial tiver notícias de novas provas poderá proceder a novas pesquisas (art. 18 do Código de Processo Penal). Realizadas essas novas pesquisas, serão elas remetidas a juízo para serem apensadas ao inquérito policial arquivado. Nesse caso, o Ministério Público poderá, com base nessas novas provas e naquelas já produzidas, propor a ação penal ou persistir no arquivamento. ${ }^{91}$

Sobre o assunto, o Supremo Tribunal Federal editou a Súmula n. 524, in verbis:

Súmula 524. Arquivado o inquérito policial, por despacho do juiz, a requerimento do promotor de justiça, não pode a ação penal ser iniciada, sem novas provas.

A redação dessa Súmula se assemelha à do artigo 18 do Projeto de Código de Processo Penal de 2001 (Projeto n. 4.209/2001) que dispunha que "arquivados os autos da investigação, por falta de base para a denúncia, havendo notícia de outras provas, a autoridade policial deverá proceder a novas diligências, de oficio, ou mediante requisição do Ministério Público". ${ }^{92}$

No direito atual, uma vez arquivado o inquérito, poderá a autoridade policial proceder a novas pesquisas se de outras provas tiver notícia. Mas a ação penal só poderá ser proposta pelo Ministério Público se de fato houver novas provas após o arquivamento. Essas novas provas hão de ser substancialmente novas, não somente formalmente novas. Se houver desarquivamento sem novas provas, estará caracterizado o constrangimento ilegal, passível de correção via habeas corpus (art. 647 e art. 648, I do Código de Processo Penal). ${ }^{93}$

\footnotetext{
91 TOURINHO FILHO, Fernando da Costa. Manual de processo penal. 14 ed. São Paulo: Saraiva, 2011, p. 152.

TUCCI, Rogério Lauria. Investigação criminal no projeto de reforma do código de processo penal. Revista do Advogado. São Paulo: Associação dos Advogados de São Paulo, ano XXIV, ${ }^{\circ}$ 78, p. 103-110, set. 2004. penal. $4^{\text {a }}$ ed. rev. amp. atual. Rio de Janeiro: Forense, 2010, p. 390.
} 
Não é prova nova a simples oitiva de uma testemunha que não foi inquirida antes do arquivamento. Essa prova é formalmente nova. Prova substancialmente nova é aquela capar de mudar, de fato, o rumo das investigações, tal qual o encontro da arma do crime com as impressões digitais do suposto autor do fato.

Fala-se também em preclusão consumativa da decisão de arquivamento quando ocorrer a situação prevista no artigo 28 do Código de Processo Penal em primeiro grau de jurisdição ou quando houver promoção de arquivamento pelo órgão do Ministério Público atuante nos Tribunais - hipótese em que não é possível a aplicação do citado dispositivo legal. ${ }^{94}$

Segundo tal tese - preclusão consumativa - se um órgão do Ministério Público pedir o arquivamento do inquérito policial ou de peças de informação, não poderá outro membro do mesmo órgão oferecer denúncia se não observada a regra do art. 28 do Código de Processo Penal, em primeiro grau de jurisdição, ou sem ela nos Tribunais, haja vista que tal situação afrontaria o princípio do promotor natural quando a denúncia não se basear em outras provas, causando a nulidade do processo irregularmente iniciado após a anterior promoção de arquivamento. ${ }^{95}$ Dessa forma, a decisão do órgão jurisdicional que arquiva inquérito policial a pedido do Ministério Público por falta de provas faz coisa julgada formal, só modificável se o novo curso do inquérito policial ou o oferecimento da denúncia vierem acompanhados de novas provas.

O desarquivamento do inquérito não será possível se tiver ocorrido a prescrição durante o prazo em que permaneceu arquivado, eis que a decisão de arquivamento não interrompe nem suspende o prazo prescricional. ${ }^{96}$

Foi dito que o arquivamento do inquérito policial não faz coisa julgada material, salvo algumas hipóteses. É que há casos em que o arquivamento decorreu de requerimento do Ministério Público e de decisão do juiz decidindo o "mérito da causa". É a hipótese da decisão que reconheceu ser o fato atípico, não ter ocorrido o fato apurado, não ser o

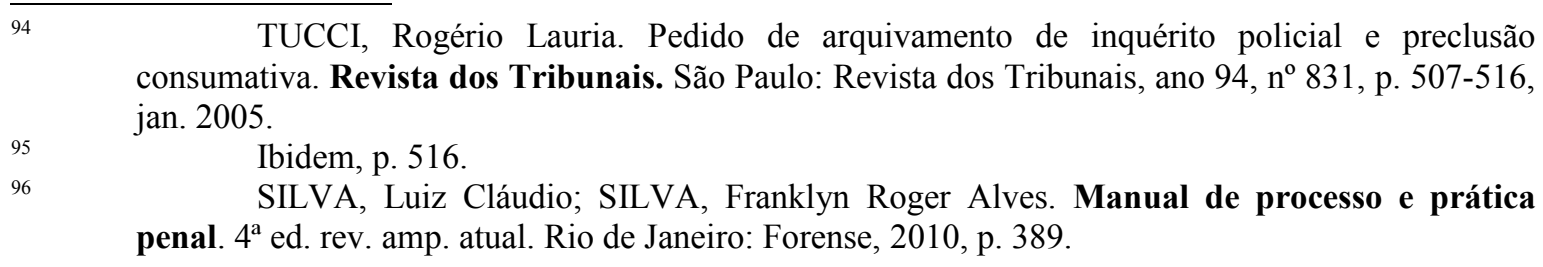
consumativa. Revista dos Tribunais. São Paulo: Revista dos Tribunais, ano 94, nº 831, p. 507-516, jan. 2005.

$95 \quad$ Ibidem, p. 516.

96 SILVA, Luiz Cláudio; SILVA, Franklyn Roger Alves. Manual de processo e prática penal. $4^{\text {a }}$ ed. rev. amp. atual. Rio de Janeiro: Forense, 2010, p. 389. 
investigado o autor do fato (art. 386, I, II e IV do Código de Processo Penal), estar extinta a punibilidade pela decadência do direito de queixa, pela renúncia ou pela prescrição da pretensão punitiva (art. 107, IV e V), por exemplo. Nesses casos, é evidente, não se pode desarquivar inquérito, haja vista que o prosseguimento das investigações estaria obstado, pois em nenhum desses casos estaria autorizada a propositura da ação penal pela análise do mérito (quanto à atipicidade do fato, inexistência do fato ou de não ser o investigado o autor do crime) ou pela extinção da punibilidade (pela decadência do direito de queixa, renúncia ou prescrição).

Outra hipótese que impede o desarquivamento é o reconhecimento de qualquer das causas excludentes da ilicitude ${ }^{97}$, tais como o reconhecimento de que o indiciado agiu em legítima defesa, estado de necessidade, em exercício regular de direito ou em estrito cumprimento do dever legal (art. 23 do Código Penal). No mesmo sentido, Há entendimento no sentido de que o reconhecimento de causa de exclusão de culpabilidade, salvo a inimputabilidade, também impediria o desarquivamento. ${ }^{98}$

Por fim, importante acrescentar que o desarquivamento depende de requerimento do Ministério Público nos crimes de ação penal pública ou do ofendido (ou de quem tenha qualidade para representá-lo) nos crimes de ação penal privada, de modo que não pode ser determinado de ofício pelo juiz.

\section{Justa causa para instauração e prosseguimento do inquérito policial}

Ao tecermos as considerações iniciais sobre o trancamento do inquérito policial, falamos que o fundamento para sua ocorrência seria a falta de justa causa.

E o que é justa causa para a instauração do inquérito policial?

\footnotetext{
97 CARVALHO, Djalma Eutímio de. Curso de processo penal. $2^{\text {a }}$ ed. rev. atual. Rio de Janeiro: Forense, 2009, p. 56.

$98 \quad$ Ibidem, mesma página.
} 
Em doutrina, o conceito de justa causa normalmente é tratado para abordar os casos de coação ilegal previstos no artigo 648 do Código de Processo Penal, notadamente seu inciso I, que fundamentam a concessão de habeas corpus.

Há as seguintes definições para justa causa: a causa que, pelo Direito, bastaria, se ocorresse, para a coação $0^{99}$; o fato cuja ocorrência torna lícita a coação ${ }^{100}$; a causa legal ${ }^{101}$; o motivo legítimo ${ }^{102}$; aquela sem a qual não tem base em lei a coação ${ }^{103}$.

Para José Frederico Marques, justa causa é o legítimo interesse, que “ocorre sempre que o ato coativo provenha de prática ilícita, por parte de quem sofre a coação, uma vez que só existe legítimo interesse na realização de algum ato jurídico, quando este é correlato a algum fato ilícito que torne cabível a limitação ao ius libertatis". ${ }^{104}$

Além disso, entende que a justa causa é o "conjunto de elementos e circunstâncias que tornem viável a pretensão punitiva". ${ }^{105}$

Destarte, as definições acima relacionam a justa causa com a legalidade da coação à liberdade pessoal, ou seja, com a "causa fundada na lei que torna legal a restrição imposta ao direito de ir e vir". ${ }^{106}$

A justa causa é, pois, em sentido amplo, o motivo lícito, conforme o Direito, situação fática que fundamenta uma situação jurídica, o motivo previsto em lei e que pode ser invocado para justificar alguma coisa, ou seja, diz respeito aos motivos que tornam legítimo um fato. Sua ausência acarreta o abuso do direito ${ }^{107}$.

\footnotetext{
MIRANDA, Pontes de. História e prática do habeas corpus. Atualizado por Vilson Rodrigues Alves. $3^{\mathrm{a}}$ ed. Campinas: Bookseller, 2007, v. 2, p. 172.

100 FERREIRA, Pinto. Teoria e prática do habeas corpus. $4^{\mathrm{a}}$ ed. São Paulo: Saraiva, 1988, p. 45.

101 GUIMARÃES, Aureliano. O habeas corpus: doutrina, prática e jurisprudência. São Paulo: Saraiva, 1925, p. 50. BORGES DA ROSA, Inocêncio. Comentários ao código de processo penal. $3^{\mathrm{a}}$ ed. São Paulo: Revista dos Tribunais, 1982, p. 778.

TORNAGHI, Hélio. Curso de processo penal. $5^{\text {a }}$ ed. São Paulo: Saraiva, 1988, v. 2, p. 405. MARQUES, José Frederico. Elementos de direito processual penal. Rio de Janeiro: Forense, 1965, v. 4, p. 397. MARQUES, José Frederico. Tratado de direito processual penal. São Paulo: Saraiva, 1980, v. 2, p. 73 .

MOURA, Maria Thereza Rocha de Assis. Justa causa para a ação penal: doutrina e jurisprudência. In: Coleção de Estudos de Processo Penal Prof. Joaquim Canuto Mendes de 
No que diz respeito ao inquérito policial, em primeiro lugar, é preciso que tenha por fim investigar um fato que seja definido pela lei como uma infração penal, ou seja, que a norma penal defina determinada conduta como um crime - lembrando-se que as infrações penais de menor potencial ofensivo e as contravenções penais dispensam a instauração de inquérito policial, bastando mero termo circunstanciado (art. 61 da Lei n. 9.099, de 28-91995) - imputando ao seu autor uma pena corporal, de forma isolada ou cumulativamente com multa, ainda que seja ela passível de conversão em pena restritiva de direitos (art. 44 do Código Penal).

Evidentemente, não teria nenhum sentido instaurar um inquérito policial para apurar conduta sujeita a mera punição administrativa, como a aplicação de uma multa de trânsito, ou de um ilícito civil, como os prejuízos decorrentes de um acidente de veículos sem vítimas.

A essa previsão legal de uma conduta considerada criminosa se dá o nome de tipicidade.

Além de ser instaurado o inquérito para investigar uma infração penal, deve ele ser dirigido para apurar o suposto autor da infração, ou seja, deve o inquérito policial se direcionar a investigar alguém como provável ou possível autor de um crime.

Faltando qualquer desses dois pressupostos, não há justa causa para a instauração ou o prosseguimento de inquérito policial, podendo ser ele trancado ${ }^{108}$, encerrando-se definitivamente as investigações em curso.

A questão da justa causa está ligada ao regular exercício da ação penal, visto que sua ausência torna a acusação temerária e leviana. ${ }^{109}$

Por óbvio, como o trancamento do inquérito policial determina seu encerramento prematuro em decorrência de falta de justa causa para seu prosseguimento, essa decisão faz

\footnotetext{
108 GRECO FILHO, Vicente. Manual de processo penal. $8^{\mathrm{a}}$ ed. rev. amp. atual. São Paulo: Saraiva, 2010, p. 85.

109 JARDIM, Afrânio Silva. Arquivamento e desarquivamento do inquérito policial. Revista de Processo. São Paulo: Revista dos Tribunais, ano IX, nº 35, p. 264-276, abr./jun. 1984.
} 
coisa julgada, o que significa que não pode haver seu desarquivamento, ainda que surjam novas provas (art. 18 do Código de Processo Penal).

Aqui, quando se fala em desarquivamento, como já exposto, não quer isso dizer que o trancamento seja a mesma coisa que arquivamento, embora o ato de enviar os autos do inquérito policial ao arquivo por conta da decisão que acolheu pedido de seu trancamento com ele se assemelhe, visto que são situações diversas e com fundamentos distintos, mas o uso daquele termo - desarquivamento - é usado no sentido de retorno do trâmite de seus atos após a decisão que determinou seu encerramento por ausência de justa causa.

De toda forma, não tem cabimento a instauração de um inquérito policial se ele não se direcionar a apurar a conduta de alguém que não seja o provável ou possível autor de um crime.

Ainda sobre a denominação justa causa, Paulo Roberto da Silva Passos sustenta ser o motivo considerado justo pela lei e que exprime toda razão que serve para justificar alguma coisa, concluindo que "é assim o motivo que possa ser alegado porque está amparado em lei ou procede de fato justo". ${ }^{110}$

E arremata que "a justa causa, pois, identifica-se com o justo impedimento, a impossibilidade comprovada, a razão jurídica, a imposição legal, a premência provada, enfim, com tudo o que possa justamente servir de motivo ou dar origem a um fato jurídico. Assim, também se entendia como justo título". ${ }^{111}$

Destarte, a justa causa é aquela situação de direito que pode ser invocada para justificar algum ato ou fato jurídico. No caso de sua ausência, faltará justo motivo para a prática de determinado ato. No caso do inquérito policial, a falta de justa causa pode ser invocada pelo investigado para justificar o pedido de seu trancamento, dada a ausência de pressuposto para o seu prosseguimento.

Contudo, a verificação da ausência de justa causa no inquérito policial deve ser apreciada em cada caso concreto levado ao conhecimento do juiz quando houver o pedido PASSOS, Paulo Roberto da Silva. Do "habeas corpus": coação ilegal. São Paulo: Edipro, 1991, p. 78.

111 Ibidem, mesma página. 
de seu trancamento com base nesse fundamento. Assim, não se pode estabelecer antecipadamente se há ou não justa causa para a instauração ou prosseguimento do inquérito policial, cabendo a apreciação da situação fática em cada caso concreto.

Portanto, caso haja alguma dúvida sobre a presença de justa causa com a análise do caso concreto pelo juiz, deve-se prestigiar a continuidade das investigações, ou, nas palavras de Manoel Messias Barbosa, "na medida em que paire alguma procedência, ou mesmo simples possibilidade de veracidade da imputação, a investigação se faz indispensável, cumpridas todas as formalidades impostas pela lei processual, uma das quais é, exatamente, o indiciamento do apontado autor da infração investigada". ${ }^{112}$

Ademais, para ele "se na instauração do inquérito policial a atipia não está plenamente demonstrada, se a eventual falta de justa causa não é logo perceptível, como dispersa do confronto de provas, havendo ao contrário, em tese, configuração de fato delituoso, trancar simplesmente o inquérito policial corresponde a absolver sumariamente e sem processo. E isso, por certo, não é de admitir". ${ }^{113}$

Para Antônio Alberto Machado, "como vimos anteriormente, o inquérito policial poderá ser trancado em caso de indiciamento sem justa causa. Se não estiverem presentes os elementos desta última (tipicidade, indícios de autoria e punibilidade do fato e do agente), o indiciamento vai configurar verdadeiro constrangimento ilegal, porquanto é medida que sempre estabelece algum tipo de atrito com as liberdades públicas fundamentais do indivíduo, sobretudo com a liberdade de locomoção e com o direito de ser presumido inocente". ${ }^{114}$

Assim, segundo esse último autor, além da tipicidade e dos indícios de autoria, mais dois pressupostos devem estar presentes para que haja justa causa, ou seja, punibilidade do fato e do agente.

A punibilidade do fato diz respeito, a nosso ver, não aos pressupostos da justa causa, mas, na verdade, a verdadeiras causas que fundamentam o trancamento do inquérito

\footnotetext{
112 BARBOSA, Manoel Messias. Inquérito policial. $7^{\mathrm{a}}$ ed. rev. atual. São Paulo: Método, 2009, p. 42. 113 Ibidem, p. 43.

114 MACHADO, Antônio Alberto. Curso de processo penal. $3^{\mathrm{a}}$ ed. aum. atual. São Paulo: Atlas, 2010, p. 82.
} 
policial, como, por exemplo, a falta de representação nos crimes de ação penal pública condicionada para o início do inquérito policial ou a prescrição.

A punibilidade do agente, por sua vez, não tem relação com justa causa, eis que se trata de pressuposto de aplicação de pena no caso de inimputabilidade por doença mental ou desenvolvimento mental incompleto ou retardado (artigo 26 do Código Penal) e, no caso de menoridade, embora não se fale em crime, mas em ato infracional, justifica-se a instauração de procedimento para aplicação das medidas socioeducativas previstas no Estatuto da Criança e do Adolescente (Lei n. 8.069, de 13 de julho de 1990).

Resumindo, em caso de ausência de justa causa, que deve ser apreciada em cada caso concreto pelo juiz, deverá este trancar o inquérito policial, determinando o encerramento das investigações.

1.16

\section{Correlação entre justa causa para o inquérito policial e para a ação penal}

Vimos no item anterior os pressupostos para a instauração e o prosseguimento do inquérito policial, sem os quais não se fala em justa causa.

No presente item, abordaremos a justa causa para a ação penal e sua correlação com a justa causa no inquérito policial, indicando como é tratada a questão em alguns países.

Contudo, é possível afirmar que, em vários países, a justa causa para a ação penal passa, necessariamente, pela análise dos elementos de prova colhidos durante a fase investigativa a fim de se averiguar se tais elementos apontam a ocorrência de um crime e indícios mínimos de autoria suficientes para submeter a pessoa investigada a um julgamento. 
O Direito norte-americano fala em "probable cause", ou seja, causa provável, para fundamentar a realização de buscas e apreensões quando houver suspeita razoável para acreditar que pessoas ou coisas se localizam em determinados locais ou que uma dada pessoa cometeu um crime. ${ }^{115}$

A "probable cause" tem relação com a expedição de mandado de busca ou de prisão por um magistrado, haja vista que é determinada com base em testemunhos ou declarações sob juramento. A $4^{\mathrm{a}}$ Emenda à Constituição norte-americana assegura que o mandado só pode ser expedido com base nessa "probable cause". Destarte, a $4^{a}$ Emenda assegura a liberdade das pessoas contra buscas ou prisões realizadas sem indícios mínimos que justifiquem sua expedição, de modo que sua ausência é considerada uma invasão à privacidade. ${ }^{116}$

João Gualberto Garcez Ramos fala em dois princípios muito relevantes para o processo penal norte-americano contidos na $4^{\mathrm{a}}$ Emenda: o primeiro veda buscas $\mathrm{e}$ apreensões desarrazoadas (reasonableness clause); o segundo veda a expedição de mandados de busca e apreensão "sem causa provável e sem particular descrição do local a ser buscado e das coisas a serem apreendidas"117. Esse segundo princípio seria a "probable cause" acima citada.

Além disso, segundo ele, a $4^{\mathrm{a}}$ emenda determina que os mandados "somente serão expedidos com particular descrição do lugar a ser buscado e das coisas ou pessoas a serem apreendidas, tudo suportado por juramento ou afirmação por parte da autoridade policial que o solicitou". ${ }^{118}$ Daí porque não se admite a expedição de mandados de busca genéricos, sendo mesmo necessário que a autoridade policial indique o que deseja buscar. Caso seja expedido sem tais exigências, as provas obtidas com a busca serão consideradas ilícitas, embora a Suprema Corte tenha decidido que a autoridade policial possa apreender coisas não indicadas no mandado, desde que estritamente relacionadas com o crime que motivou sua expedição (Andersen v. Maryland, 427 US 463 (1976)). ${ }^{119}$

\footnotetext{
115 MOURA, Maria Thereza Rocha de Assis. Justa causa para a ação penal: doutrina e jurisprudência. In: Coleção de Estudos de Processo Penal Prof. Joaquim Canuto Mendes de Almeida. São Paulo: Revista dos Tribunais, 2001, v. 5, p. 226. Ibidem, p. 226-227. RAMOS, João Gualberto Garcez. Curso de processo penal norte-americano. São Paulo: Revista dos Tribunais, 2006, p.127. Ibidem, p.132. Ibidem, mesma página.
} 
Assim, a "probable cause" tem estrita ligação com a justa causa para instauração de investigação.

O mesmo fundamento da "probable cause", mas já na fase da ação penal, serve de justificativa para o recebimento da acusação quando for grande a possibilidade de condenação se ela - probable cause - demonstrar a existência de um crime e indícios de ter ele sido cometido pelo imputado. Portanto, se os elementos de prova colhidos durante a fase da investigação - evidence - não forem suficientes para demonstrar a "probable cause", de modo a haver indícios de que o imputado cometeu um crime, rejeita-se a acusação. Ao contrário, se a demonstrarem, a acusação é recebida. ${ }^{120}$

Portanto, a "probable cause" do Direito norte-americano seria a justa causa para a investigação e para a ação penal.

Importante consignar que o processo penal norte-americano possui três fases: a primeira é a fase de investigação - investigatory stage -; a segunda é a fase preliminar ao início do processo penal e é denominada - adjudicatory stage ${ }^{-121}$, onde a acusação é deduzida formalmente pelo prosecutor, ocasião em que são analisadas as provas apresentadas, sendo esse o momento adequado para a verificação da "probable cause" pelo juiz, bem como analisará a licitude das provas e sua admissibilidade em caso de possível ação penal; por fim, ultrapassada a segunda fase, presente a "probable cause" e admitidas as provas colhidas durante a investigação, tem início a fase judicial.

Com relação ao júri, a $6^{\mathrm{a}}$ Emenda à Constituição americana determina que a fase da investigação se desenvolva perante o "grande júri" quando o delito praticado for "crime capital ou por outra razão infame", desde que a Constituição do Estado-Membro tenha adotado o "grande júri" ou que se trate de crime federal. ${ }^{122}$

\footnotetext{
120 MOURA, Maria Thereza Rocha de Assis. Justa causa para a ação penal: doutrina e jurisprudência. In: Coleção de Estudos de Processo Penal Prof. Joaquim Canuto Mendes de Almeida. São Paulo: Revista dos Tribunais, 2001, v. 5, p. 227. RAMOS, João Gualberto Garcez. Curso de processo penal norte-americano. São Paulo: Revista dos Tribunais, 2006, p.177.

$122 \quad$ Ibidem, p.178.
} 
O Código de Processo Penal italiano é mais específico ao abordar a relação da justa causa para a investigação com a justa causa para a ação penal.

Segundo o artigo 408 do Código de Processo Penal italiano, quando o Ministério Público verificar que a notícia do crime não tiver fundamento após o término das indagações preliminares - indagini preliminari -, deverá apresentar ao juiz pedido de arquivamento. E assim atuará o Ministério Público porque o artigo 125 do mesmo estatuto dispõe que assim deverá agir quando os elementos obtidos nas indagações preliminares não forem idôneos para sustentar a acusação em juízo. ${ }^{123}$

Como se percebe, o direito italiano não trata a questão da justa causa com vistas ao resultado da ação - possível condenação -, mas sob a ótica da existência ou não de elementos suficientes para sustentar a ação penal, o que, a nosso ver, é mais correto, uma vez que não vincula a atuação do Ministério Público ao número de prováveis condenações, mas à existência ou não de crime e indícios de autoria.

Por sua vez, o artigo 411 do Código de Processo Penal italiano dispõe que não se procede à acusação se falta uma condição de procedibilidade, se a punibilidade está extinta, ou se o fato não é previsto, pela lei, como crime. As duas últimas hipóteses, como veremos, são causas que fundamentam o trancamento do inquérito policial no Direito brasileiro.

Se não houver objeção da vítima e o juiz da investigação preliminar acatar a proposta de arquivamento do Ministério Público, determinará o retorno dos autos a este órgão. Caso contrário, se rejeitar a proposta de arquivamento, designará data para a realização de audiência a se realizar em colegiado. Ao final dessa segunda audiência, se não for acatado o pedido de arquivamento do Ministério Público, o parquet deverá proceder à acusação no prazo de dez dias, sendo designada, no prazo de dois dias, data para a realização de audiência preliminar (Código de Processo Penal italiano, art. 409). ${ }^{124}$

\footnotetext{
123 MOURA, Maria Thereza Rocha de Assis. Justa causa para a ação penal: doutrina e jurisprudência. In: Coleção de Estudos de Processo Penal Prof. Joaquim Canuto Mendes de Almeida. São Paulo: Revista dos Tribunais, 2001, v. 5, p. 227.

124 PERRODET, Antoinette. O sistema italiano. In: DELMAS-MARTY, Mireille (org.). Processos penais da Europa. Trad. Fauzi Hassan Choukr, com a colaboração de Ana Claudia
} 
Se o Ministério Público não pedir o arquivamento, mas, ao contrário, entender que foi praticado um crime e que há indícios de ser o imputado seu autor, oferecerá a peça acusatória - richiesta di rinvio a giudizio -, onde deverá delinear os fatos, as circunstâncias agravantes e situações que possam justificar a adoção de medidas de segurança, indicando as fontes de prova ${ }^{125}$ e será designada uma audiência preliminar, onde deverão estar presentes o órgão do Ministério Público, o imputado, seu defensor e o juiz que, após analisar as provas produzidas na fase investigativa e os argumentos das partes, seguirá um dos dois caminhos: receberá a acusação ou prolatará o arquivamento da acusação sentenza di non luogo a procedere -, conforme os artigos 416 a 424. A data da audiência preliminar será designada pelo juiz das investigações preliminares no prazo de dois dias contados do requerimento do Ministério Público e será realizada dentro de trinta dias. $\mathrm{O}$ juiz para as investigações preliminares e o juiz para a audiência preliminar não podem ser a mesma pessoa (Código de Processo Penal italiano, art. 34). ${ }^{126}$

A função essencial da audiência preliminar, segundo Mario Chiavario, "è quella di fornire una prima sede di controllo giurisdizionale, nella logica di un contestuale ascolto delle ragioni delle parti, per vagliare la consistenza dell'iniziativa portata avanti dall'organo dell'accusa e per evitare - anzitutto all'imputato ma anche alla collettività - $i$ costi (son soltanto economici) di um dibattimanto non necessario" ${ }^{127}$, ou seja, é para fornecer uma primeira sede de controle jurisdicional, na lógica contextual de oitiva das razões das partes, para avaliar a consistência da iniciativa levada adiante pelo órgão de acusação e para evitar - sobretudo ao imputado mas também à coletividade - os custos (não somente econômicos) de uma discussão não necessária.

O juiz pronunciará a sentença de arquivamento quando houver uma causa que extinga o crime ou que impeça o início da ação penal; quando o fato não for definido em lei como crime; se não ocorreu o fato; se o imputado não é o autor do fato; se o fato existiu, mas não é considerado crime; se o investigado não é imputável ou punível (Código de Processo Penal italiano, art. 425).

125
126
127

Ferigato Choukr. Rio de Janeiro: Lumen Juris, p. 343-429, 2005.

Ibidem, p. 369-370.

Ibidem, p. 369.

CHIAVARIO, Mario. Diritto Processuale Penale. Quarta edizione. Torino: Utet Giuridica, 2009, p. 429. 
Entretanto, esta decisão não faz coisa julgada, de modo que é possível o reinício das investigações quando surgirem novas fontes, assemelhando-se a hipótese ao disposto em nosso Código de Processo Penal, artigo 18. Nas palavras de Mario Chiavario "va precisato che, una volta disposta l'archiviazione, il procedimento penale potrà pur essere riatttivato, con una riapertura delle indagini, autorizzata dal g.i.p. stesso a seguito di una richiesta del publlico ministero (art. 414 CPP), e sul semplice pressupposto dell' $\{\{\text { esigenza di nuove investigazioni }\}\}^{" 128}$, ou seja, é certo que, uma vez determinado o arquivamento, o procedimento penal poderá ser reativado, com a reabertura das indagações, autorizada pelo mesmo juiz das investigações preliminares após pedido do Ministério Público (Código de Processo Penal italiano, art. 414).

Sendo assim, a acusação só é recebida no processo penal italiano após a análise dos elementos colhidos durante a fase investigativa para se apurar a existência de justa causa.

Importante consignar que no processo penal italiano a finalidade da investigação preliminar não é a reconstituição de provas visando o julgamento, mas o "conjunto de atividades de investigação na ótica decisória a fim de que o Ministério Público exercite ou não a ação penal". ${ }^{129}$ Portanto, a fase de investigação preliminar tem por fim a apuração da ocorrência de crime e verificação da existência de indícios de autoria para que o titular da ação penal possua elementos para o pedido de início da ação penal após a realização da audiência preliminar perante o magistrado, conforma acima delineado. À exceção dos atos irrepetíveis - atti irripetibili -, os elementos de prova obtidos durante a fase preliminar não são passíveis de serem transpostos à fase de julgamento, salvo se houver consentimento das partes para que se tenha acesso aos registros escritos efetuados durante a investigação (Lei n. 479, de 19 de dezembro de 1999). ${ }^{130}$ Assim, a justa causa para a ação penal deve ser aferida com base nos elementos de prova colhidos durante a fase preliminar de investigação, o que será averiguado na audiência preliminar designada pelo juiz para a decisão sobre o arquivamento ou início da ação penal.

O papel do Ministério Público no sistema italiano é de fundamental importância, visto que dirige a investigação preliminar para verificar a presença da justa causa do

\footnotetext{
Ibidem, p. 56.

129 PERRODET, Antoinette. O sistema italiano. In: DELMAS-MARTY, Mireille (org.). Processos penais da Europa. Trad. Fauzi Hassan Choukr, com a colaboração de Ana Claudia Ferigato Choukr. Rio de Janeiro: Lumen Juris, p. 343-429, 2005.

$130 \quad$ Ibidem, p. 361.
} 
inquérito e da ação penal, mas esse dever faz relevar sua função imparcial ao se agregar a esse ônus o de reunir as circunstâncias que sejam favoráveis àquele que esteja sendo investigado. Por outro lado, também dá relevância à função de defensor, haja vista que prevê poderes para que ele pratique atos investigativos na busca de elementos de prova em favor da pessoa que defende, podendo entrevistar pessoas - e tem poder de autenticar as respectivas declarações - e entrar em determinados lugares com autorização judicial, por si ou por agentes privados (Lei n. 397, de 7 de dezembro de 2000). Esses elementos de prova produzidos pelo defensor são juntados a autos específicos denominados "autos da defesa". ${ }^{131}$

Assim, na Itália, não só o Ministério Público, mas também a defesa pode atuar com vistas à produção de provas que auxiliem o juiz na análise da presença ou não de justa causa para a investigação e para a ação penal.

\subsubsection{Sistema francês}

No sistema francês, os juizes e os membros do Ministério Público constituem "um corpo único de juristas profissionais formados pela Escola Nacional da Magistratura". ${ }^{132}$

O Ministério Público exerce a ação penal pública (Código de Processo Penal francês, art. 31), sendo indispensável sua presença. Tal qual ocorre no sistema inglês, o Ministério Público tem discricionariedade para o início da persecução penal, avaliando a base legal da persecução e se é apropriado exercitá-la. ${ }^{133}$ Os membros do Ministério Público estão sujeitos à autoridade do Ministro da Justiça. ${ }^{134}$

$\mathrm{Na}$ investigação preliminar, o juiz de instrução pode atuar tanto como investigador quanto como juiz. Como investigador, deverá recolher os elementos de prova, tanto a favor, como contra a pessoa investigada - como ocorre no sistema italiano, mas lá tal papel cabe ao Ministério Público. Como juiz, pode determinar o uso de força pública e mesmo o 
encarceramento da pessoa investigada. Após a conclusão das investigações, decide, por requerimento do Ministério Público, pelo encaminhamento ou não da pessoa investigada a julgamento. Evidentemente, é nesse momento processual que o juiz verifica a existência ou ausência da justa causa para o encerramento das investigações ou para o início da ação penal, demonstrando a correlação entre a justa causa para o inquérito e para a ação penal.

No Direito francês, a finalidade da investigação preliminar é "encontrar informações que sirvam ao órgão de persecução para decidir ou não pelo seu exercício; a investigação é secreta e sem audiência". ${ }^{135}$ Os trabalhos da investigação são realizados pela polícia, sob a supervisão e direção do procurador da República (Código de Processo Penal francês, artigos 38 e $41, \S 2^{\circ}$ ).

O Ministério Público pode, em qualquer fase da investigação, determinar o arquivamento do caso quando a infração não puder ser mais alvo de persecução em decorrência de algum limite temporal, como a prescrição, ou em razão de seu poder discricionário para prosseguir com a persecução. Caso decida pela persecução, tratando-se de investigação de crime, deverá provocar o juiz de instrução por meio de requerimento formal, onde pleiteia a investigação dos fatos. ${ }^{136}$ Diferentemente do direito italiano, nessa fase o suspeito não pode pedir nenhuma investigação.

Segundo o disposto no artigo 176 do Código de Processo Penal francês, após o término das investigações, o juiz de instrução deverá examinar se existem indícios da prática de crime pela pessoa investigada. ${ }^{137} \mathrm{O}$ artigo 80 , alínea 1 , por sua vez, dispõe que o juiz de instrução poderá examinar todas as pessoas sobre as quais haja indícios que façam presumir ter elas participado, como autoras ou cúmplices, de fatos delituosos.

Caso conclua que os fatos investigados não constituam crime, que a autoria não foi esclarecida, ou não haja indícios suficientes contra a pessoa investigada, deverá proferir sentença declarando que não há lugar à persecução - ordonnance de non-lieu. ${ }^{138}$ Essa decisão pode ter por fundamento questão de Direito, quando o juiz concluir que os fatos

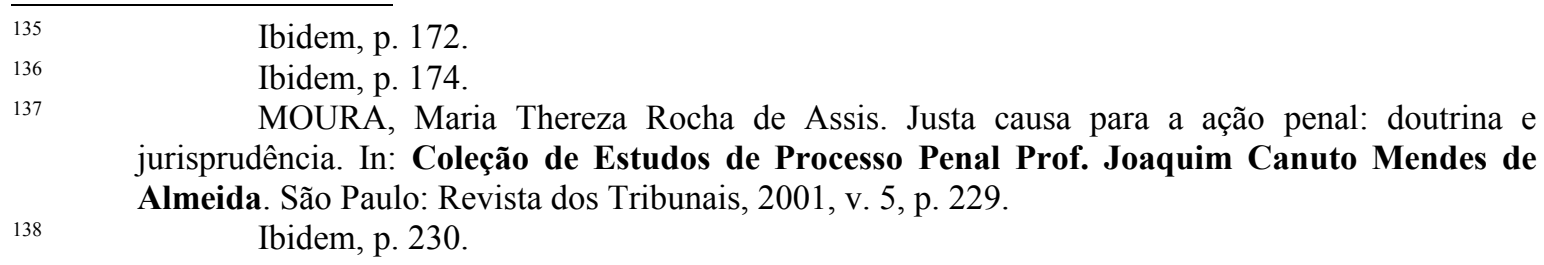


não são qualificáveis (fato cível, anistia, fato justificável) ou não são passíveis de persecução (prescrição, inimputabilidade, coisa julgada), ou questão de fato, quando a autoria é desconhecida, não haja nenhuma acusação ou sejam elas insuficientes. ${ }^{139}$ Quando se fundamentar em questão de Direito, essa sentença terá efeito de coisa julgada absoluta; quando o fundamento for questão de fato, a decisão terá efeito de coisa julgada relativa, de modo que se surgirem novas provas, pode-se reabrir a investigação (Código de Processo Penal francês, artigos 188 e 189). ${ }^{140}$

Em sentido contrário, se verificar a ocorrência de crime, deverá prolatar sentença encaminhando o caso ao tribunal competente e, ao mesmo tempo, determinará o encaminhamento dos elementos de prova do procurador da república ao procurador geral atuante na corte de apelação para o procedimento próprio (Código de Processo Penal francês, artigos 178,179 e 181). ${ }^{141}$

A análise da viabilidade ou não da acusação é feita em audiência designada pelo juiz de instrução para tal fim em caso de persecução de crime. Essa audiência é denominada instrução ou informação. Seu objetivo é "buscar as provas do cometimento de uma infração, de descobrir seu autor caso este seja desconhecido ou de verificar a justa causa para a imputação levada a efeito contra uma pessoa determinada" ${ }^{142}$ e servirá para que o juiz decida se envia ou não o caso a julgamento de mérito.

Em primeira instância, o julgamento de crimes compete ao escabinado, que é composto por três juízes profissionais ${ }^{143}$ - sendo um deles o presidente e os demais assessores - e nove jurados - o júri. A Corte e o júri deliberam "conjuntamente sobre a culpa do acusado e sobre a pena". ${ }^{144}$

\footnotetext{
$139 \quad$ Ibidem, mesma página.

Ibidem, mesma página.

Ibidem, mesma página.

DERVIEUX, Valérie. O sistema francês. In: DELMAS-MARTY, Mireille (org.). Processos penais da Europa. Trad. Fauzi Hassan Choukr, com a colaboração de Ana Claudia Ferigato Choukr. Rio de Janeiro: Lumen Juris, p. 151-242, 2005.

Fala-se em juizes profissionais, visto que a Lei Orgânica de 19 de janeiro de 1995 criou um corpo de juízes não profissionais denominados "temporários" que atuarão em primeira instância ou no Tribunal de Grande Instância, indicados para um mandato único de sete anos, com os mesmos poderes dos juízes de carreira, sendo escolhidos dentre candidatos indicados pela assembleia geral de juízes de carreira das Cortes de apelação após um período de treinamento.

DERVIEUX, Valérie. O sistema francês. In: DELMAS-MARTY, Mireille (org.). Processos penais da Europa. Trad. Fauzi Hassan Choukr, com a colaboração de Ana Claudia Ferigato Choukr. Rio de Janeiro: Lumen Juris, p. 151-242, 2005.
} 


\section{Sistema português}

O principal protagonista dos atores processuais no sistema português é o juiz de instrução, ao qual compete proceder à instrução, decidir quanto à pronúncia e exercer todas as funções jurisdicionais até a remessa do processo para julgamento (art. 17 do Código de Processo Penal português), o qual será realizado pelos tribunais judiciais de primeira instância, sejam eles coletivos ou singulares (artigos 14 e 16 do Código de Processo Penal) ou pelo tribunal do júri (art. 13 do mesmo estatuto), cada qual com sua competência delimitada de acordo com sua função processual.

Papel de especial relevância no processo penal português exerce o Ministério Público, o qual exerce a ação penal pública (art. 219.1 da Constituição portuguesa e art. 48 do Código de Processo Penal), dirige o inquérito policial e promove a execução das penas e medidas de segurança (art. 53.2, " $b$ ” e " $e$ ”, do Código de Processo Penal).

Além destes, também exercem função importante os órgãos de polícia criminal, visto que a eles compete a investigação da autoria e materialidade dos delitos, bem como levar a cabo os atos necessários e urgentes destinados a assegurar os meios de prova (art. 55.2 do Código de Processo Penal). Atuam sob a direção das autoridades judiciárias (juiz de instrução e Ministério Público) e na sua dependência funcional (art. 56 do Código de Processo Penal).

O investigado pela prática de algum delito é denominado arguido e conserva tal denominação durante todo o decurso da persecução penal (Código de Processo Penal, art. 57, itens 1 e 2). Da combinação deste dispositivo com o estatuído no art. 58.2, que dispõe o inicio do procedimento processual penal por meio de comunicação, oral ou escrita, dirigida ao arguido, bem como pelo disposto no art. 61.1, itens "a" e "b", que asseveram o direito de comparecer aos atos processuais e ser ouvido diretamente pelo tribunal quando alguma decisão que lhe afete venha a ser proferida, conclui-se que conserva tal denominação não apenas na fase do inquérito policial, mas também durante a tramitação do procedimento deduzido para ao final vir a ser pronunciado ou não. 
O defensor exerce múnus relevante, eis que a ele compete proceder à defesa do arguido (artigos 62 a 64 do Código de Processo Penal).

O assistente no processo penal português não é só o ofendido ou seus sucessores, mas também qualquer pessoa nos crimes contra a paz e a humanidade, bem como nos de tráfico de influência, favorecimento pessoal praticado por funcionário, denegação de justiça, prevaricação, corrupção, peculato, participação econômica em negócio, abuso de poder e de fraude na obtenção ou desvio de subsídio ou subvenção (art. 68.1, "e" do Código de Processo Penal). Pode intervir em qualquer altura do processo e se subordina ao Ministério Público, do qual é colaborador (artigos 68.3 e 69.1 do Código de Processo Penal).

Por fim, são admitidas no processo penal as partes civis, as quais formularão pedido de indenização civil fundado na prática de um crime, somente deduzindo o pedido perante um tribunal civil nas hipóteses previstas em lei (Código de Processo Penal, artigos 71 e 72). Será realizada verdadeira instrução para julgamento do pedido civil, com contestação, produção de provas e julgamento (Código de Processo Penal, artigos 77 a 80).

Ocorrendo um delito, sua notícia pode chegar ao Ministério Público por conhecimento próprio, por meio de denúncia ou por meio dos órgãos de polícia criminal (Código de Processo Penal, art. 241). É formado o denominado auto de notícia, com todos os elementos necessários e que deve ser encaminhado ao Ministério Público no prazo mais curto possível, não podendo exceder o prazo de dez dias (Código de Processo Penal, art. 243.3).

Quando a notícia do crime é informada aos órgãos da polícia criminal, antes mesmo de receberem ordem para agir, deverão tomar as medidas cautelares apropriadas para conservar os elementos de prova necessários para a elucidação do delito, como proceder a exames dos vestígios do crime, colher informações das pessoas que tiverem conhecimento de algum elemento importante para a elucidação dos fatos e apreender os objetos relacionados ao delito (Código de Processo Penal, artigos 248 e 249). De qualquer forma, deverão informar o Ministério Público no prazo máximo de dez dias (Código de Processo Penal, art. 248). 
Realizadas as diligências necessárias, os órgãos da polícia criminal reúnem os elementos colhidos em relatório, onde mencionam de forma resumida as investigações, os resultados das provas colhidas e a descrição dos fatos apurados, remetendo-o ao Ministério Público ou ao juiz da instrução (Código de Processo Penal, art. 253).

De todo modo, sem prejuízo do auto de notícia, a notícia de um crime sempre dá lugar à abertura do inquérito que, como já dito, é dirigido pelo Ministério Público, que é assistido pelos órgãos da polícia criminal (Código de Processo Penal, artigos 262 e 263). Nele deve constar o conjunto de diligências que visam investigar a existência de um crime, determinar seus agentes e recolher provas para eventual acusação (Código de Processo Penal, art. 262).

A despeito de o inquérito ser dirigido pelo Ministério Público, há atos que o Código de Processo Penal determina sejam praticados somente com autorização do juiz da instrução, os quais vêm elencados pelos artigos 268 e 269, dentre os quais proceder ao primeiro interrogatório judicial do averiguado, mas, que no geral, dizem respeito a atos que importem restrição aos direitos fundamentais do investigado, tal qual a busca e apreensão de bens, apreensão de correspondência ou determinação de realização de escutas telefônicas.

Além desse procedimento, existem ainda os procedimentos especiais, que são o procedimento sumário, o procedimento abreviado e o procedimento sumaríssimo, cada qual com suas especificidades próprias, mas que são cabíveis normalmente nos delitos cuja pena máxima não seja superior a cinco anos (artigos 381, 391-A e 392 do Código de Processo Penal).

Encerrado o inquérito, ao Ministério Público cabe uma das seguintes alternativas: proceder ao arquivamento, mediante despacho, se os elementos de prova indicarem a não ocorrência de crime, de não ter o suspeito praticado o delito, se for legalmente inadmissível o procedimento ou se forem insuficientes os indícios de ocorrência de crime ou de autoria (Código de Processo Penal português, art. 277); em sentido contrário, se os elementos colhidos durante a investigação apontarem a ocorrência de crime e indícios de autoria, deduzirá contra o suspeito a acusação (Código de Processo Penal português, art. 283). 
Além disso, poderá o Ministério Público, de ofício ou a pedido do arguido ou do assistente, em caso de delito que preveja pena não superior a cinco anos e desde que o investigado cumpra os requisitos legais, tais como ausência de condenação anterior, ausência de suspensão provisória anterior e concordância com a medida, suspender provisoriamente o processo, cuja homologação compete ao juiz de instrução, e desde que o arguido cumpra algumas regras de conduta também apontadas na lei, como indenizar o lesado, prestar serviços comunitários, não frequentar certos lugares. O prazo de suspensão será de até dois anos, à exceção de alguns delitos ligados a crimes sexuais, onde o prazo poderá durar até cinco anos (Código de Processo Penal, artigos 281 e 282).

Deduzida a acusação pelo Ministério Público, pode o suspeito e o assistente requerer a instrução que tem por fim "a comprovação judicial da decisão de deduzir acusação ou de arquivar o inquérito em ordem a submeter ou não a causa a julgamento" (Código de Processo Penal português, art. 286).

A direção da instrução compete ao juiz da instrução (Código de Processo Penal, art. 288).

Na instrução, cabe ao juiz de instrução determinar a realização dos atos que entenda necessários para a apuração da verdade e julgamento da causa e deverá conter um debate instrutório, oral e contraditório, do qual podem participar todos os sujeitos processuais, à exceção das partes civis (Código de Processo Penal, art. 289).

São admissíveis na instrução todas as provas que não forem proibidas por lei (Código de Processo Penal, art. 292).

Encerrado o debate, o juiz de instrução deverá, no mesmo ato ou após lhe serem os autos trazidos conclusos, proferir a decisão de pronúncia ou de não pronúncia, apontando as razões de fato e de direito para decidir se o arguido será levado a julgamento ou não (Código de Processo Penal, art. 307). A decisão que pronunciar o arguido é irrecorrível (Código de Processo Penal, art. 310). 
A decisão de pronúncia nada mais é do que o reconhecimento da viabilidade ou não da acusação. Em caso de pronúncia, determinará a remessa dos autos ao Tribunal competente para o julgamento.

Uma vez remetidos os autos ao Tribunal competente, compete ao seu presidente decidir as questões preliminares ou prejudiciais à análise do mérito. Também compete ao presidente a decisão sobre a rejeição da acusação, se a considerar infundada (Código de Processo Penal português, art. 311). Considera-se infundada a acusação quando ela não tem condições de viabilidade, como, por exemplo, quando "os fatos descritos na acusação não integrarem qualquer infração penal" ${ }^{145}$, incluindo-se a rejeição da denúncia por "notória insuficiência de prova indiciária". ${ }^{146}$

Entendemos que a decisão de pronúncia, ou seja, de viabilidade da acusação, demanda análise da justa causa para que o suspeito seja submetido a julgamento, e essa análise passa não só pela apuração do aspecto formal da acusação, mas também pela verificação dos elementos de prova colhidos durante a investigação, de modo que é necessária a presença de justa causa para o inquérito e para a ação penal, demonstrando sua correlação, para que seja dado prosseguimento à acusação com vistas ao julgamento da ação penal.

\subsubsection{Sistema espanhol}

O processo penal espanhol é dividido em duas fases: em primeiro lugar, há a instrução preliminar ou fase pré-processual; após, há a fase do juízo oral ou fase processual propriamente $\operatorname{dita}^{147}$. A primeira fase é inquisitória, ao passo que a segunda tem por característica o sistema acusatório ${ }^{148}$. Na fase pré-processual, há a figura do juiz de instrução.

\footnotetext{
145 MOURA, Maria Thereza Rocha de Assis. Justa causa para a ação penal: doutrina e jurisprudência. In: Coleção de Estudos de Processo Penal Prof. Joaquim Canuto Mendes de Almeida. São Paulo: Revista dos Tribunais, 2001, v. 5, p. 231. Ibidem, mesma página. LOPES JUNIOR, Aury. Sistemas de investigação preliminar no processo penal. $2^{\mathrm{a}}$ ed. Rio de Janeiro: Editora Lumen Juris, 2003, p. 219.

$148 \quad$ Ibidem, mesma página.
} 
Como na Espanha há o juiz de instrução, que participa ativamente da colheita de provas para apuração do fato delituoso, não pode ele atuar na fase processual, visto que fica excluída sua competência pela prevenção, tendo em vista sua parcialidade ${ }^{149}$.

O Ministério Público - que lá é denominado Ministerio Fiscal - é o titular da ação penal pública, ao passo que o particular ofendido é o titular da ação privada. Uma peculiaridade do sistema espanhol é a figura do denominado autor popular, ou seja, nos crimes de ação penal pública, pode qualquer pessoa do povo, ainda que não seja vítima, exercer a ação penal. É possível, então, que no polo ativo da ação penal pública estejam o Ministério Público, o acusador popular e a vítima habilitada no processo (Constituição Espanhola, art. 125 e Código de Processo Penal, art. 101).

A instrução preliminar é subdividida em três sistemas: o sumário, as diligências prévias - que é um procedimento abreviado - e a instrução complementar. O primeiro é utilizado para os processos que seguem o rito ordinário, para delitos graves com pena superior a nove anos; o segundo serve para vasta gama de crimes cuja pena não seja superior a nove anos, à exceção dos crimes de competência do Júri - em tal sistema predomina a oralidade e a concentração de atos e previu maior participação do Ministério Público ao lado do juiz instrutor; por fim, a instrucción complementaria se destina a preparar a fase processual nos processos de competência do Tribunal do Júri ${ }^{150}$.

Encerrada a investigação, denominada sumario, presidida pelo juiz de instrução, os autos serão encaminhados ao Tribunal competente. No Tribunal, o juiz designado deverá, em três dias, decidir pela instrução ou pelo sobrestamento do feito (quando não houver provas de participação de algum investigado no delito ou mesmo provas de sua ocorrência). Se decidir pela instrução, as partes serão notificadas para comparecer a uma audiência no prazo de dez dias, onde se decidirá pelo recebimento da acusação ou sua rejeição, para que tenha início a fase judicial (Código de Processo Penal espanhol, art. 622 e ss.). 
Essa fase intermediária entre a investigação e o início da ação penal tem por fim possibilitar ao Tribunal competente a análise da justa causa da investigação e também da ação penal respectiva.

\subsubsection{Sistema inglês}

O aspecto mais interessante do sistema inglês é o fato de não existir um Código de Processo Penal. As regras que regulam o direito processual estão distribuídas dentre uma série de textos legislativos que passaram a ser criados a partir do século XII e por uma "jurisprudência abundante". ${ }^{151}$

A ausência de um Código de Processo Penal, contudo, não significa que há um completo vácuo no sistema processual. Servem como fontes de direito processual, por exemplo, a Magna Carta de 1215, o Bill of Rights de 1688 e o Ato sobre Direitos Humanos - Human Rights Act - de 1988, que incorporou grande parte da Convenção Europeia de Direitos do Homem. ${ }^{152}$

Da mesma forma, a jurisprudência exerce importante papel, visto que um conjunto de julgados interpreta a legislação esparsa e ainda serve de fonte para regular o processo penal inglês. ${ }^{153}$

Nesse país, os juízes profissionais são nomeados pela Coroa inglesa por recomendação do Lorde Chanceler. De um modo geral, existem os juízes das Cortes Superiores, responsáveis pelo julgamento dos casos mais graves e das apelações, que são escolhidos dentre os profissionais com mais de dez anos de experiência, os juízes do Circuito e registradores, responsáveis pelo julgamento da maior parte dos casos, os juízes de Distrito - conhecidos como magistrados com estipêndio -, que são escolhidos dentre profissionais com mais de sete anos de experiência, registradores assistentes, que esperam

\footnotetext{
151 SPENCER, J. R. O sistema inglês. In: DELMAS-MARTY, Mireille (org.). Processos penais da Europa. Trad. Fauzi Hassan Choukr, com a colaboração de Ana Claudia Ferigato Choukr. Rio de Janeiro: Lumen Juris, p. 245-339, 2005.

Ibidem, p. 247

Ibidem, p. 249.
} 
ser indicados para os postos de juízes profissionais e atuam a convite do Lorde Chanceler sem a garantia de vitaliciedade. ${ }^{154}$

Além desses, há os juízes leigos que são nomeados pelo Lorde Chanceler, em nome da Rainha, e desempenham sua função até a aposentadoria compulsória (aos setenta anos) ou até pedirem exoneração. Não tem vitaliciedade e podem ser dispensados pelo Lorde Chanceler sem que nenhuma razão seja dada. ${ }^{155}$

Em primeiro grau de jurisdição, há a Corte dos Magistrados, composta por três juízes, na sua maioria juízes leigos, conhecidos como Juízes de Paz, e com juízes profissionais denominados Juízes de Distrito. Os juízes leigos nunca decidem sozinhos e são assistidos por um oficial treinado - clerk -, ao passo que os juízes profissionais podem decidir sozinhos. Ainda em primeira instância, há a Corte da Coroa, composta somente por juízes profissionais.

A acusação é realizada pelo Serviço de Persecução da Coroa - Crown Prosecution Service - e dirigido pelo Diretor das Persecuções Públicas, nomeado pelo ProcuradorGeral, e deve ter ao menos dez anos de atividade. Não goza de vitaliciedade e pode contratar operadores para atuar sob sua direção. ${ }^{156}$

O papel da defesa, por sua vez, é exercido por dois profissionais: os solicitors e os barristers. Os primeiros atuam na defesa dos suspeitos na Delegacia de Polícia, de forma gratuita e mediante pagamento com fundos públicos, ao passo que os segundos atuam como advogados dos réus perante a Corte da Coroa e nas demais Cortes Superiores. ${ }^{157}$

Outro dado interessante é que na Inglaterra a responsabilidade criminal começa aos dez anos. ${ }^{158}$ Além disso, caso queiram, os imputados podem conduzir sua defesa em juízo sem o defensor técnico, independentemente da acusação. ${ }^{159}$

Ibidem, p. 255.

Ibidem, p. 255-256.

Ibidem, p. 256.

Ibidem, p. 257.

Ibidem, p. 262.

Ibidem, p. 265. 
No sistema inglês, o principal requisito para que tenha inicio a persecução penal é a existência de prova suficiente - sufficient evidence. A nosso ver, esta "sufficient evidence" seria a justa causa para o início da investigação. A condução dos procedimentos criminais instaurados pela polícia é de responsabilidade do "Crown Prosecution Service", que também pode dar início a acusação que entenda apropriada. Este serviço atua na acusação do crime, não na investigação. ${ }^{160}$

A persecução penal na Inglaterra pode se iniciar de ofício pela polícia, após investigar e obter provas a respeito do crime e do suposto autor ou por informação prestada perante um magistrado - o que pode ser feito pela polícia, cidadãos ou autoridades ligadas à persecução - e que pode dar início a um procedimento com vistas à colheita de provas. Se a persecução se iniciar pela polícia, deverá remeter o caso ao "Crown Prosecution Service", onde o promotor - Crown Prosecutor - dará prosseguimento à acusação, poderá mudá-la ou encerrar o procedimento quando considerar que seu início pela polícia foi errado (Code for Crown Prosecutors, item 3). ${ }^{161}$

Ao analisar se o prosseguimento da persecução é viável ou não, o promotor deverá verificar se as provas são suficientes para uma possível condenação e se a provável atuação da defesa pode, de alguma forma, afetar a acusação. ${ }^{162}$ Além disso, deve estar presente o interesse púbico para efetuar a persecução. ${ }^{163}$ Daí porque se diz que no sistema inglês há discricionariedade na persecução. Essa análise, como dito, compete ao Crown Prosecutor.

Caso o Crown Prosecutor entenda ser o caso de não prosseguir com a persecução, determinará o arquivamento e comunicará à corte tal resolução. Caso decida por dar continuidade à persecução, deverá fazer um pedido formal, que poderá ser analisado pela corte competente para decidir se há fundamento suficiente que justifique o envio do caso a julgamento. ${ }^{164}$ É nesse momento, pois, que os órgãos judiciários farão a análise da justa causa para início da ação penal.

\footnotetext{
160 MOURA, Maria Thereza Rocha de Assis. Justa causa para a ação penal: doutrina e jurisprudência. In: Coleção de Estudos de Processo Penal Prof. Joaquim Canuto Mendes de Almeida. São Paulo: Revista dos Tribunais, 2001, v. 5, p. 233. Ibidem, p. 234. Ibidem, mesma página. SPENCER, J. R. O sistema inglês. In: DELMAS-MARTY, Mireille (org.). Processos penais da Europa. Trad. Fauzi Hassan Choukr, com a colaboração de Ana Claudia Ferigato Choukr. Rio de Janeiro: Lumen Juris, p. 245-339, 2005. Ibidem, p. 283.
} 
Se o caso for levado a julgamento pelo júri na Corte da Coroa, diversamente do sistema francês, aos juízes leigos só compete decidir sobre a culpa ou inocência do acusado, visto que a sentença compete exclusivamente ao juiz. ${ }^{165}$

1.16.7

\section{Sistema alemão}

Dado interessante do sistema processual alemão é que seu Código de Processo Penal data de $1^{\circ}$ de fevereiro de 1877 - em vigor desde $1^{\circ}$ de outubro de 1879 , ou seja, vigora já em seu terceiro século. A Lei de Organização Judiciária, do mesmo ano (1877), regula as atribuições do Ministério Público e dos órgãos de julgamento. ${ }^{166}$

A Alemanha é uma República federal composta de dezesseis Länder, que são circunscrições territoriais, cada qual com uma série de competências. ${ }^{167}$ Compete ao Ministro da Justiça de cada Länd nomear o juiz não vitalício, que só alcançará a vitaliciedade após cinco anos de sua nomeação. ${ }^{168}$

O Ministério Público é representado em cada nível de jurisdição. Assim, há o Ministério Público Federal, dirigido pelo Procurador-Geral Federal, que, por sua vez, é subordinado ao Ministro Federal da Justiça, bem como o Ministério Público das Länd, representado pelo Procurador-Geral respectivo, que é subordinado ao Ministro da Justiça da Länd respectiva. ${ }^{169}$ Dentre as atribuições do Ministério Público destaca-se a de dar início à persecução penal, dirigir o inquérito policial, determinar medidas coercitivas de urgência, exercer a ação penal pública e fiscalizar a execução penal. ${ }^{170}$ É considerado um órgão autônomo da administração da justiça, razão pela qual não se atribui a ele o papel de parte, de modo que na fase da investigação deve buscar elementos de prova contra e a favor do suspeito (Código de Processo Penal alemão, $\S 160$, II), tanto que pode recorrer em

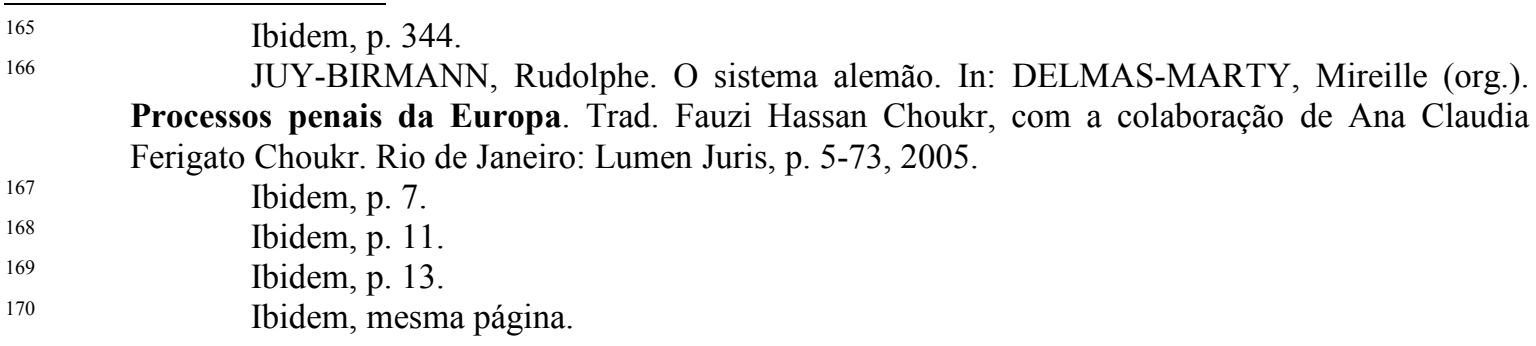


favor do réu ou solicitar a reabertura de um processo para que se reconheça a inocência de um acusado. ${ }^{171}$

Ao Ministério Público compete conduzir a investigação, embora determinados atos devam ser autorizados por um magistrado que não atuará no julgamento da causa. $\mathrm{Na}$ fase intermediária, porém, os juízes profissionais que irão julgar o mérito da causa analisam as provas produzidas na fase da investigação, o que é criticado pela doutrina em razão de tal situação afetar sua imparcialidade. ${ }^{172}$

Antes do início da persecução penal propriamente dita, há uma fase preparatória que tem por fim apurar se uma determinada infração penal pode ser atribuída a alguém (Código de Processo Penal alemão, § 151 e ss.). Inicia-se na polícia ou mediante notícia levada ao Ministério Público (Código de Processo Penal alemão, § 163). Ao Ministério Público compete dirigir as investigações. O suspeito é notificado e poderá constituir defensor (Código de Processo Penal alemão, § 137). Ao final dessa fase, o Ministério Público pode determinar o arquivamento, fundamentando-se em razões de conveniência e oportunidade, ou propor a ação penal. Antes do julgamento da ação penal, pode haver uma fase intermediária (Código de Processo Penal alemão, § 199 a 211).

A finalidade da fase intermediária é o controle sobre a decisão do Ministério Público de propor a ação penal com o fim das investigações e, além disso, formalizar o início da fase de julgamento, servindo para que se analise se há suspeita do cometimento da infração (Código de Processo Penal alemão, § 203). O pedido de início da ação penal, na fase intermediária, deve ser dirigido ao tribunal competente, que é composto por juízes profissionais. O juiz presidente, em audiência não pública, analisando os elementos de prova colhidos durante a investigação, decidirá se é possível ter início a fase de julgamento, quando verificar a verossimilhança de que o acusado possa vir a ser condenado.

Esse julgamento consiste no momento apropriado para se verificar a justa causa para a ação penal na Alemanha, tanto que, caso entenda que os elementos de prova não apontam para a verossimilhança da imputação, deverá rejeitar a acusação, decisão esta

\begin{tabular}{ll}
\hline 171 & Ibidem, p. 14. \\
172 & Ibidem, p. 19.
\end{tabular}


sujeita a recurso por parte do Ministério Público. ${ }^{173}$ Caso a decisão de rejeição seja revista pela instância superior, o caso retorna para julgamento por tribunal composto por membros diversos daqueles que proferiram a primeira decisão. Caso mantida, opera-se a coisa julgada (Código de Processo Penal alemão, $§ 211) .{ }^{174}$

Interessa ao presente estudo citar a hipótese de arquivamento da persecução penal de forma unilateral pelo Ministério Público quando se tratar de delitos de bagatela, em virtude das parcas consequências da conduta delituosa, da pena imposta (nenhum mínimo legal previsto) e da ausência do interesse na persecução (Código de Processo Penal alemão, $\S 153, \mathrm{I}, 2) .{ }^{175}$

\subsubsection{Sistema belga}

O sistema processual penal belga é misto. Na fase preliminar, ou seja, na investigação, é inquisitivo, ao passo que, na fase judicial - de julgamento - impera o sistema acusatório. Na primeira fase vigora o segredo da instrução, por vezes segredo externo e interno, ou seja, atos são praticados sem a ciência do suspeito e de seu defensor. $^{176}$

Característica marcante do processo penal belga é a separação das funções de investigação, persecução e julgamento. A investigação é realizada pelo juiz de instrução, sob a supervisão da Câmara do Conselho e da Câmara de acusação. A persecução é exercida pelo Ministério Público. Por fim, o julgamento está a cargo dos juízes. ${ }^{177}$

Vige na Bélgica o princípio da oportunidade da persecução (Código de Processo Penal belga, art. 28, quater, $\S 1)$.

\footnotetext{
$173 \quad$ Ibidem, p. 29.

$174 \quad$ Ibidem, p. 55-56.

$175 \quad$ Ibidem, p. 63.

176 PESQUIÉ, Brigitte. O sistema belga. In: DELMAS-MARTY, Mireille (org.). Processos penais da Europa. Trad. Fauzi Hassan Choukr, com a colaboração de Ana Claudia Ferigato Choukr. Rio de Janeiro: Lumen Juris, p. 77-148, 2005.

177 Ibidem, p. 83-84.
} 
O sistema judicial é complexo. É estruturado em nível federal e em onze províncias, sendo estas "subdivididas em circunscrições judiciárias, em si mesmas divididas em cantões". ${ }^{178}$

Os magistrados são selecionados por meio de concurso e devem se submeter a um estágio. Compete ao Conselho Superior da Justiça, composto por magistrados e representantes da sociedade civil, selecionar os magistrados a serem nomeados pelo Rei (Constituição Belga, art. 158). Além disso, alguns candidatos são selecionados em razão de sua experiência profissional nos meios jurídicos e judiciários, embora tenham que passar por um exame de aptidão profissional. ${ }^{179}$

Os membros do Ministério Público, por sua vez, são nomeados e destituídos pelo Rei após indicação do Ministro da Justiça (Constituição Belga, art. 153), a quem estão subordinados (Código Judiciário, art. 143).

A função de advogado é reservada aos belgas e aos integrantes de um dos países da comunidade europeia, ao doutor ou licenciado em direito e que tenha passado por estágio de três anos, além de prestar juramento. ${ }^{180}$

A fase de investigação é denominada informação. A fase intermediária é chamada de instrução e é conduzida pelo juiz de instrução, a quem compete dirigi-la. Essa fase é anterior ao recebimento da acusação. Não cabe ao juiz de instrução decidir pelo julgamento, visto que essa matéria é de competência da Câmara do Conselho. ${ }^{181}$

Após encerrada a instrução, os autos são encaminhados pelo juiz de instrução ao Procurador do Rei, a quem compete requerer formalmente o início do procedimento perante a Câmara do Conselho, que decidirá acerca do arquivamento do caso ou do recebimento da acusação, encaminhando os autos ao tribunal competente para o julgamento. ${ }^{182}$ É nesse momento que é proferida a decisão sobre a presença ou não da justa causa para o início da ação penal e da verificação da presença da justa causa na investigação.

\begin{tabular}{ll}
\hline 178 & Ibidem, p. $86-87$. \\
179 & Ibidem, p. $87-88$. \\
180 & Ibidem, p. 89. \\
181 & Ibidem, p. 109. \\
182 & Ibidem, p. 111.
\end{tabular}




\subsection{9}

\section{Sistema argentino}

O sistema processual penal argentino possui característica própria, na medida em que há um Código de Processo Penal nacional (Ley n. 23.984, de 21 de agosto de 1991), sem prejuízo da existência de alguns códigos das províncias.

No código nacional, a investigação está a cargo do juiz instrutor, que a conduz contando com o Ministério Público no papel de auxiliá-lo, tendo a polícia à disposição de ambos. $^{183}$

Tomando conhecimento da ocorrência de um crime, caberá ao Ministério Público ou à polícia requerer o início da fase instrutória, que tem por fim a investigação do delito com vistas à propositura da ação penal ou ao arquivamento do feito. ${ }^{184}$

Realizadas as investigações, cabe à acusação pedir a elevação a juízo, que corresponde ao oferecimento da denúncia ou da queixa-crime no sistema brasileiro, a realização de novas diligências, cuja realização será decidida pelo juiz de instrução ${ }^{185}$, ou o arquivamento. Além disso, é possível ser requerido o sobrestamento do feito a qualquer tempo, ainda que a instrução não esteja encerrada, mas a decisão sobre sua conveniência está a cargo do juiz de instrução. ${ }^{186}$

Entendemos que essa fase preliminar da ação penal da elevação a juízo será adequada para que o juiz de instrução verifique a presença da justa causa da investigação e da ação penal, de modo que deverá decidir pelo recebimento ou rejeição da acusação, encerrando as investigações ou dando início à fase judicial propriamente dita caso os elementos colhidos durante as investigações apontem, respectivamente, a justa causa ou sua ausência para o prosseguimento da persecução penal.

\footnotetext{
183 CHOUKR, Fauzi Hassan. Garantias constitucionais na investigação criminal. $3^{\mathrm{a}}$ ed. rev. amp. atual. Rio de Janeiro: Lumen Juris, 2006, p. 35.

Ibidem, mesma página.

Ibidem, mesma página.

Ibidem, mesma página.
} 
1.16.10 Código de processo penal modelo para ibero-américa

O Codigo Procesal Penal modelo para iberoamerica aponta como imputado aquele contra o qual haja qualquer indicação que o aponte como possível autor de um fato ou partícipe pelas autoridades responsáveis pela persecução penal que o código estabelece $\left(\right.$ art. 6). ${ }^{187}$

Durante o procedimento preparatório e antes de serem tomadas as declarações do imputado, a ele deverá haver comunicação detalhada da acusação que lhe é atribuída, com todas as circunstâncias, e será advertido de que pode permanecer calado sem que essa decisão seja utilizada em seu prejuízo, podendo exigir a presença de defensor (art. 41). Suas declarações serão prestadas perante o Ministério Público quando estiver solto ou perante o juiz de instrução, quando preso (art. 47).

O exercício da persecução penal compete ao Ministério Público, salvo quando se trate de hipótese de persecução privada, e terá como auxiliar a polícia, a qual dirigirá (art. 68).

Compete à polícia proceder à investigação sob a orientação do Ministério Público, que supervisionará o correto cumprimento dessa função (artigos 73 e 74).

A ação penal é precedida do procedimento preparatório onde o Ministério Público deverá praticar todas as diligências pertinentes para a apuração do fato e de seu autor (art. 250). Quando for manifesto que o fato não constitui crime, poderá o Ministério Público pedir o arquivamento da investigação perante o juiz de instrução (art. 251).

Quando não for hipótese de arquivamento, o Ministério Público deverá pedir por escrito ao tribunal competente a abertura do juízo, apontando as provas do fato e os indícios de que seja o imputado seu autor (art. 263). Esse procedimento é denominado intermediário e após seu desenvolvimento será recebida ou não a acusação (art. 267 e ss.).

Instituto
$<\underline{\text { http://direitoprocessual.org.br/content/blocos/76/1>. Acesso em 3.7.2012. }}$ Brasileiro 
É nessa oportunidade que será analisada a justa causa para a ação penal e a justa causa para a investigação, decidindo o tribunal pelo recebimento ou rejeição da acusação.

Antes da reforma processual realizada pela Lei n. 11.719, de 20-6-2008, não havia no Brasil o exame prévio da legitimidade e regularidade da acusação como há tempos existe nos sistemas processuais acima citados.

Essa situação já era criticada por Maria Thereza Rocha de Assis Moura, nos seguintes termos: "Em síntese, tal juízo, sempre fundamentado, contribuiria para impedir a formulação de imputações precipitadas e temerárias e diminuiria, via de conseqüência, a impetração de habeas corpus, visando ao trancamento da ação penal por falta de justa causa". 188

A crítica ao modelo anterior tinha como fundamento o fato de o arquivamento do inquérito policial, por falta de base para a denúncia e para seu oferecimento, ficar sujeito ao subjetivismo do Ministério Público, bem como no fato de sua rejeição, nas hipóteses do antigo artigo 43 do Código de Processo Penal, se escorar somente em questões de Direito. Defendia-se a possibilidade de exame prévio da acusação pelo juiz, antes de receber a denúncia ou queixa, para que acusações sem fundamento pudessem ser afastadas pelo magistrado, que a rejeitaria para preservar o inocente contra acusações injustas. ${ }^{189}$

De toda forma, a despeito da não existência, no direito anterior, de um exame prévio da legitimidade da acusação antes do recebimento da denúncia ou queixa, verdade é que já se defendia a análise da justa causa para a ação penal para fins de recebimento ou rejeição da acusação quando fosse evidente a divergência entre as provas colhidas durante a investigação e a acusação oferecida para fins de ação penal, para que se evitasse coação e constrangimento ilegal ao acusado. ${ }^{190}$

\footnotetext{
188 MOURA, Maria Thereza Rocha de Assis. Justa causa para a ação penal: doutrina e jurisprudência. In: Coleção de Estudos de Processo Penal Prof. Joaquim Canuto Mendes de Almeida. São Paulo: Revista dos Tribunais, 2001, v. 5, p. 237. Ibidem, mesma página. Ibidem, p. 237-238.
} 
Assim é que, para que houvesse justa causa para o recebimento da denúncia ou queixa, havia a necessidade de prova induvidosa da existência do crime e prova de indícios mínimos de autoria apurados no inquérito policial ou outras peças de informação, sem os quais a acusação deveria ser rejeitada. ${ }^{191}$ Essa apuração devia ser feita a partir do caso concreto.

A evidente correlação entre a justa causa para o inquérito policial e para a ação penal é traçada por Maria Thereza Rocha de Assis Moura da seguinte maneira: "Tanto é que o Ministério Público deve requerer o arquivamento do inquérito se entender que não há base para a formulação da denúncia. Sob determinado ângulo, tal procedimento dá-se porque reconhecida a falta de justa causa para o processo criminal, que atinge o status dignitatis do indivíduo". ${ }^{192} \mathrm{E}$ arremata: "Tanto a doutrina como a jurisprudência têm aceitado o trancamento do inquérito policial por falta de justa causa, quando o fato investigado não seja relevante para o Direito penal ou quando não haja possibilidade, em tese, de ser o investigado o autor da infração...". 193

Sendo assim, já antes da reforma processual realizada pela Lei n. 11.719, de 20-62008, restava evidente a correlação entre a justa causa para o inquérito policial e para a ação penal.

Após o advento de referida legislação, o artigo 395 do Código de Processo Penal passou a ter nova redação prevendo as hipóteses de rejeição da denúncia ou queixa e elevou a falta de justa causa para o exercício da ação penal (inciso III) como situação que pode fundamentar a rejeição da peça acusatória, seja liminarmente, seja após a citação do acusado para apresentar resposta escrita no prazo de dez dias (Código de Processo Penal, art. 396, na redação que the foi dada pela Lei n. 11.719, de 20-6-2008), que foi outra questão resolvida pela reforma, visto que, a partir de sua criação no mundo jurídico pátrio, o sistema processual brasileiro seguiu a tendência de outras legislações modernas no sentido de possibilitar ao juiz o exame prévio da legitimidade da acusação antes de dar início à ação penal ${ }^{194}$, tal qual ocorre com os sistemas processuais europeus acima citados,

\footnotetext{
Ibidem, p. 241.

$192 \quad$ Ibidem, p. 243.

193 Ibidem, mesma página.

194 SANTOS, Leandro Galluzzi dos. Procedimentos. In: MOURA, Maria Thereza Rocha de Assis (coord.). As reformas no processo penal. São Paulo: Revista dos Tribunais, 2004, p. 298-
} 344. 
muito embora, esse mesmo juiz responsável pelo recebimento ou rejeição da acusação seja o mesmo que irá analisar o mérito da causa, o que não ocorre em alguns sistemas europeus, eis que, como visto, possuem um juiz de instrução responsável pela função de recebimento da acusação, não sendo ele que irá julgar a causa.

Portanto, com a citada reforma processual, tornou-se mais evidente o que já era defendido antes, ou seja, que há correlação entre a justa causa para o inquérito policial e para a ação penal.

Aliás, a correlação entre a ação penal e o inquérito policial é clara, na medida em que, ausentes as condições da ação penal, como possibilidade jurídica do pedido ou ilegitimidade de parte, torna-se inviável a abertura ou prosseguimento de inquérito policial. Dessa forma, se possível o trancamento da ação penal, também é possível o trancamento do inquérito policial, o que normalmente é feito por habeas corpus. ${ }^{195}$ É o que ocorre quando o fato for atípico ou a ação penal for iniciada por requisição judicial quando dependia de representação do ofendido ou de seu representante - ação penal pública condicionada - ou quando dependia da iniciativa do ofendido ou de seu representante ação penal privada, ou, ainda, se já tiver extinta a punibilidade. ${ }^{196}$

Ora, se a finalidade do inquérito policial é apurar autoria e materialidade, ou seja, colher os elementos necessários para que as condições da ação penal sejam preenchidas, torna-se evidente a correlação entre o inquérito policial e a ação penal. ${ }^{197}$

Uma vez estabelecidos os pressupostos para a investigação policial, com instauração do inquérito policial, ou seja, apuração de fato definido como crime e voltado contra suposto autor da infração - que representam a justa causa -, cabe a análise dos casos

\footnotetext{
195 SIQUEIRA, Geraldo Batista de. Inquérito policial - requisição judicial. Revista Jurídica do Rio Grande do Sul. Porto Alegre: Síntese - Notadez, ano XXXVII, nº 147, p. 42-45, jan. 1990. Ibidem, p. 43. COUTINHO, Jacinto Nelson de Miranda. A natureza cautelar da decisão de arquivamento
do inquérito policial. Revista de Processo. São Paulo: Revista dos Tribunais, ano $18, n^{\circ} 70$, p. 4958, abr./jun. 1993.
} 
que podem levar à decretação do trancamento do inquérito policial. Os instrumentos utilizados para tal mister serão tratados em capítulo específico.

Como hipóteses em que a instauração ou prosseguimento do inquérito policial acarretariam constrangimento ilegal autorizadoras de seu trancamento por via do habeas corpus, Weber Martins Batista aponta a apuração de fato inexistente ou penalmente lícito ou quando é evidente que o investigado não seja seu autor. ${ }^{198}$ Contudo, aponta conclusão registrada no Centro de Estudos do Tribunal de Alçada Criminal do Rio de Janeiro - hoje extinto - decorrente de sua proposição diferenciando as situações no seguinte sentido: "a falta de prova de autoria não pode levar ao trancamento do inquérito, pois uma das finalidades deste é exatamente a busca dessa prova, mas se, ao invés de falta de prova, há induvidosa prova de que o indiciado não é o autor do fato, prosseguir com o procedimento contra ele constitui constrangimento ilegal". ${ }^{199}$ E conclui que nessas hipóteses deve a autoridade policial encaminhar os autos do inquérito a juízo para arquivamento, visto que se assim não proceder estará caracterizada a coação ilegal passível de correção por via do habeas corpus. ${ }^{200}$

Portanto, para Batista o trancamento do inquérito policial por meio do habeas corpus é exceção, só admissível nos casos de “desvio de poder ou manifesta ilegalidade". ${ }^{201}$ Para corroborar seu entendimento, cita aresto relatado pelo Ministro do Supremo Tribunal Federal Sidney Sanches segundo o qual 'para se trancar um inquérito policial via habeas corpus, mister se faz que os fatos narrados demonstrem de forma absolutamente clara e evidente, que a ação não constitui crime' (RTJ, 122/76). ${ }^{202}$

Assim, as primeiras causas que podem acarretar o constrangimento ilegal a justificar o trancamento do inquérito policial são: fato inexistente, atipicidade da conduta investigada e, por fim, for evidente que o investigado não seja o autor da infração penal.

\footnotetext{
198 BATISTA, Weber Martins. Trancamento de inquérito policial. Revista Forense. Rio de Janeiro: Forense, ano 90, no 328, p. 101-104, out./dez. 1994.

Ibidem, p. 101.

Ibidem, mesma página.

Ibidem, p. 102.

Ibidem, mesma página.
} 
No entanto, não são somente estas as hipóteses em que é possível o trancamento do inquérito policial. Há outras hipóteses em que é possível o encerramento prematuro das investigações.

Passamos, doravante, a tratá-las separadamente, sistematizando os casos em que é possível o trancamento do inquérito policial.

\subsubsection{Inexistência do fato}

Na primeira hipótese, ou seja, inexistência do fato, é possível citar como exemplo o caso de a autoridade policial instaurar inquérito policial para apurar o homicídio de uma vítima que está viva e que jamais sofreu qualquer atentado contra ela. Como é evidente a inexistência de infração penal, a simples instauração do inquérito contra alguém lhe acarretará constrangimento ilegal a ser corrigido por meio de seu trancamento.

\subsubsection{Fato atípico}

A tipicidade é elemento primordial do crime, visto que por ela se produz a adequação de uma conduta ou ação a um tipo penal que modela e define o fato criminoso. $^{203}$

O tipo penal, ou simplesmente tipo, é constituído em sua estrutura notadamente do verbo que exprime a ação ou conduta, que é o núcleo do tipo, e mais os elementos objetivos que se agregam à ação. ${ }^{204}$

É evidente, pois, o constrangimento ilegal que decorre da investigação de fato atípico. $\mathrm{O}$ fato é típico quando uma conduta praticada se adéqua à descrição prevista na lei penal. É atípico, em sentido contrário, quando a ação humana não se adéqua a nenhuma conduta prevista em lei penal.

\footnotetext{
203 MARQUES, José Frederico. Tratado de direito penal: da infração penal. Campinas: Millennium, 2002, v. II, p. 72.

$204 \quad$ Ibidem, p. 76.
} 
Se a conduta humana não se enquadrar em um fato típico, há ausência de tipicidade, ou seja, o fato é atípico. ${ }^{205}$ Difere a atipicidade da ausência de ação. O fato somente é relevante para a figura penal quando houver ação relevante para o Direito Penal. ${ }^{206}$

A atipicidade pode ser classificada em específica ou total. É específica quando uma conduta, embora aparente se adequar a um tipo penal, se devidamente analisada verificarse que não se subsume a ele. É o que ocorria em caso do antigo crime de sedução (art. 217 do Código Penal, revogado pela Lei n. 11.106, de 28-3-2005), quando a mulher tivesse mais de 18 anos. É total quando a conduta não se adequar a qualquer elemento dos tipos penais, como acontece em caso de não pagamento de dívida que, embora imoral, não é considerado crime. ${ }^{207}$

Em qualquer desses exemplos, se houver instauração de inquérito policial para investigar tais fatos, com todas as suas consequências - indiciamento, comparecimento para atender a convocação da autoridade policial, gastos com advogado, etc. - é evidente que o investigado passa por constrangimento ilegal, uma vez que o fato é atípico.

Sendo assim, ante a atipicidade da conduta, o inquérito policial pode ser trancado para que se encerrem imediatamente as investigações, pondo-se fim a elas, sem possibilidade de novas investigações.

Ademais, a simples possibilidade futura de impedimento de ir e vir com a instauração do inquérito policial, na ausência de tipicidade, é fato relevante a ensejar pedido de seu trancamento.

1.17.3

Investigado que não é o autor do fato

Da mesma forma, se for evidente que o investigado não seja o autor da infração penal, o inquérito policial pode ser trancado para se encerrarem as investigações. Nessa hipótese, o fato é existente, a conduta é típica, mas o investigado não é evidentemente seu autor.

\begin{tabular}{ll}
\hline 205 & Ibidem, p. 87. \\
206 & Ibidem, mesma página. \\
207 & Ibidem, p. 87-88.
\end{tabular}


Weber Martins Batista aborda a forma de análise do material colhido no inquérito para a decisão de seu trancamento no seguinte sentido: "Muitas vezes, talvez se possa dizer, na maioria dos casos o pedido de trancamento do inquérito envolve o exame minucioso e aprofundado de toda prova existente, sua valoração subjetiva, sua análise crítica - o que refoge do campo restrito do habeas corpus, devendo ser objeto de apreciação do juiz de primeiro grau, no momento em que receber ou rejeitar a denúncia ou a queixa". ${ }^{208}$

Essa hipótese é mais delicada. O conhecimento de que o investigado não é o autor do fato deve ser evidente, claro, preciso, indubitável, perceptível à primeira vista. Se houver qualquer dúvida sobre quem seja o autor da infração penal, o investigado ou terceira pessoa, então o inquérito policial há de ser necessariamente instaurado para apurar quem foi o autor do delito, se o investigado ou outra pessoa, não se falando, nessa situação, em constrangimento, de modo que não poderá ser trancado o inquérito policial instaurado para apurar a autoria do delito.

\subsubsection{Crime impossível}

Segundo o disposto no artigo 17 do Código Penal, "não se pune a tentativa quando, por ineficácia absoluta do meio ou por absoluta impropriedade do objeto, é impossível consumar-se o crime".

O crime impossível também é denominado quase crime, tentativa inidônea ou inadequada. ${ }^{209}$

É meio absolutamente inidôneo aquele que, em razão de sua essência ou natureza, não tem capacidade de produzir o resultado. ${ }^{210}$ Pode-se citar como exemplo a conduta de

\footnotetext{
208 BATISTA, Weber Martins. Trancamento de inquérito policial. Revista Forense. Rio de Janeiro: Forense, ano 90, nº 328, p. 101-104, out./dez. 1994.

209 JESUS, Damásio Evangelista de. Direito penal: parte geral. $32^{\mathrm{a}}$ ed. rev. atual. São Paulo: Saraiva, 2011, v. 1, p. 393.

210 FRAGOSO, Heleno Cláudio. Lições de direito penal. 15 ed. rev. atual. Rio de Janeiro: Forense, 1994, p. 248.
} 
indivíduo que ministra água à vítima ao invés de utilizar veneno ou a conduta de alguém que deseja envenenar um inimigo, mas dá-lhe açúcar ao invés de arsênico ${ }^{211}$.

A impropriedade absoluta do objeto, por sua vez, é aquela em que este não existe ou, mesmo existindo, dependendo das circunstâncias, é impossível a consumação do delito. É o exemplo de ingestão de substância abortiva quando não existe gravidez ou cadáver alvejado por disparos de arma de fogo. ${ }^{212}$

Em tais hipóteses, caso seja instaurado inquérito policial, é patente o constrangimento ilegal sofrido pelo imputado, motivo pelo qual, não havendo crime, seja pela absoluta inidoneidade do meio ou por absoluta impropriedade do objeto, é possível o trancamento do inquérito policial.

\subsubsection{Crime putativo}

O crime putativo ocorre quando o agente supõe, por erro, praticar fato criminoso quando, na verdade, sua conduta não tem qualquer relevância penal. É uma espécie de erro de proibição ao revés. ${ }^{213}$ É o caso do agente que pratica conjunção carnal com a irmã maior e capaz, crendo estar praticando crime, quando, na verdade, não existe o crime de incesto no ordenamento pátrio. ${ }^{214}$

O crime putativo também ocorre quando há um agente provocador que induz o indivíduo a praticar um crime para ser preso em flagrante. Há quem denomine o crime putativo de crime imaginário, visto que só existe na imaginação do agente ${ }^{215}$.

\footnotetext{
211 NORONHA, E. Magalhães. Direito penal. Atualizado por Adalberto José Q. T. de Camargo Aranha. 31 a ed. São Paulo: Saraiva, 1995, v. 1, p. 130.

212 FRAGOSO, Heleno Cláudio. Lições de direito penal. 15 ed. rev. atual. Rio de Janeiro: Forense, 1994, p. 249.

Ibidem, mesma página.

MIRABETE, Julio Fabbrini; FABBRINI, Renato N. Manual de direito penal: parte geral. 26 ed. rev. atual. São Paulo: Atlas, 2010, v. 1, p. 153.

NORONHA, E. Magalhães. Direito penal. Atualizado por Adalberto José Q. T. de Camargo Aranha. $31^{\text {a }}$ ed. São Paulo: Saraiva, 1995, v. 1, p. 131.
} 
Em vista disso, o Supremo Tribunal Federal editou a Súmula 145, segundo a qual "não há crime, quando a preparação do flagrante pela polícia torna impossível sua consumação".

A situação prevista na Súmula 145 do Supremo Tribunal Federal também é denominada flagrante preparado. ${ }^{216}$ Difere o flagrante preparado do flagrante esperado, visto que, neste último caso, não há agente provocador. ${ }^{217}$

Portanto, caso o fato investigado no inquérito policial decorra de crime putativo ou flagrante preparado, é possível ao imputado requerer seu trancamento, pedindo o fim das investigações.

Praticado um fato descrito na norma penal e não havendo uma causa excludente da antijuridicidade, estará caracterizado o crime. Assim, o crime é fato típico e antijurídico.

A antijuridicidade é a contradição entre a conduta praticada pelo agente e o ordenamento jurídico $^{218}$, ou seja, é a conduta típica contrária ao direito ${ }^{219}$.

Assim, em princípio, o fato típico é antijurídico, ou seja, a tipicidade é um indício da antijuridicidade.

Contudo, o próprio ordenamento jurídico prevê hipóteses em que a antijuridicidade é excluída do fato típico. Desse modo, em princípio, a conduta daquele que mata outra pessoa é fato típico e antijurídico, haja vista que tal situação se amolda ao artigo 121 do Código Penal que trata do crime de homicídio em suas diversas formas. Porém, se essa conduta tiver sido praticada em legítima defesa, embora o fato seja típico, está excluída sua antijuridicidade, de modo que não há crime, eis que o próprio ordenamento excluiu a

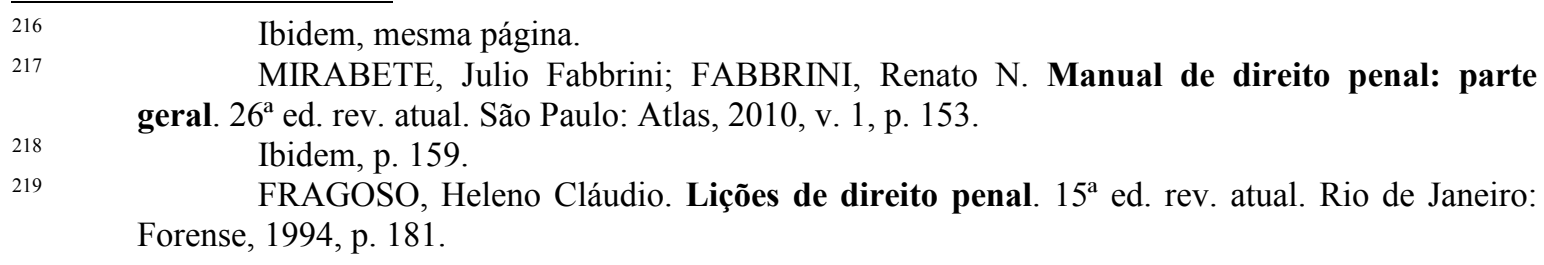


antijuridicidade do fato ao prever a legítima defesa como causa excludente (Código Penal, artigos 23, II e 25).

As causas excludentes da antijuridicidade também são chamadas causas excludentes da ilicitude, eximentes ou descriminantes. ${ }^{220}$ São causas que excluem a antijuridicidade o estado de necessidade, a legítima defesa, o estrito cumprimento do dever legal e o exercício regular de direito (Código Penal, art. 23).

Quando o agente tiver praticado fato descrito na lei penal em alguma dessas hipóteses, não há crime (artigo 23, caput do Código Penal).

Além dessas hipóteses previstas na Parte Geral do Código Penal, outras existem na Parte Especial que excluem a antijuridicidade do fato, tais como a prática de aborto por médico quando não houver outro meio de salvar a vida da gestante ou a gravidez resultar de estupro (Código Penal, art. 128), a ofensa irrogada em juízo pela parte ou seu procurador na discussão da causa, a opinião desfavorável da crítica literária, artística ou científica e o conceito desfavorável emitido por funcionário público, em apreciação ou informação que preste no cumprimento de dever de ofício (Código Penal, art. 142).

Além das causas excludentes previstas no ordenamento, há quem defenda a existência de causas supralegais de exclusão da antijuridicidade. O fundamento dessa doutrina reside na impossibilidade de o ordenamento jurídico prever todas as hipóteses em que a conduta do agente, apesar de típica, tenha excluída sua antijuridicidade. São citados como exemplos o poder de correção dos pais em relação aos filhos menores, impondo-lhes castigos, assim como as penalidades impostas pelos professores sem a previsão nos regulamentos escolares, desde que aplicados sem abusos, ou mesmo o consentimento expresso do ofendido quando praticados danos a seus bens disponíveis. ${ }^{221}$

Não se admite o uso de regras de integração para punir fatos não previstos na lei penal. Nesse campo, vige o princípio da reserva legal, ou seja, não há crime sem lei anterior que o defina (Código Penal, art. $1^{\circ}$ ).

\footnotetext{
220 MIRABETE, Julio Fabbrini; FABBRINI, Renato N. Manual de direito penal: parte geral. $26^{a}$ ed. rev. atual. São Paulo: Atlas, 2010, v. 1, p. 161.

$221 \quad$ Ibidem, p. 162.
} 
No entanto, não prevalece esse principio para as normas penais não incriminadoras, de modo que é possível o recurso das regras de integração, tais como a analogia, os costumes e os princípios gerais do direito (Lei de Introdução ao Código Civil, art. $4^{\circ}$ ) com vistas a ser excluída a antijuridicidade de determinados fatos ${ }^{222}$, de modo que por meio de tal processo de integração é reconhecida a existência de causas supralegais de exclusão da antijuridicidade.

Para que se configure a causa de exclusão da antijuridicidade, necessário o preenchimento dos requisitos objetivos e subjetivos, ou seja, além da presença de todos os elementos constantes da norma justificadora, também é preciso que o sujeito conheça a situação de fato justificante. ${ }^{223}$

Destarte, se alguém pratica fato típico, mas acobertado por uma causa de exclusão da antijuridicidade, não há crime. Caso instaurado inquérito policial para apurar a conduta praticada pelo agente e se ficar delineado que agiu mediante uma dessas causas, poderá o investigado requerer o trancamento do inquérito policial para que seja imediatamente encerrado.

Passemos à análise de cada uma das causas de exclusão da antijuridicidade previstas no artigo 23 do Código Penal lembrando, no entanto, que o presente estudo se refere a tema de Direito Processual Penal, de modo que os tópicos seguintes não têm a finalidade de esgotar o assunto, mas indicar as causas que fundamentam o trancamento do inquérito policial.

1.18.1

Estado de necessidade

Segundo o dispõe o Código Penal, "considera-se em estado de necessidade quem pratica o fato para salvar de perigo atual, que não provocou por sua vontade, nem podia de outro modo evitar, direito próprio ou alheio, cujo sacrifício, nas circunstâncias, não era razoável exigir-se" (art. 24).

\footnotetext{
222 JESUS, Damásio Evangelista de. Direito penal: parte geral. 32 ed. rev. atual. São Paulo: Saraiva, 2011, v. 1, p. 407.

$223 \quad$ Ibidem, p. 404.
} 
Sendo assim, a ação é justificada pela necessidade que impõe o sacrifício de um bem em situação de conflito ou colisão, permitindo o ordenamento jurídico o sacrifício do bem de menor valor. ${ }^{224}$

Os requisitos objetivos para o reconhecimento do estado de necessidade são os apresentados pelo texto da lei: perigo atual não provocado pelo agente e inevitável, salvaguarda de direito próprio ou alheio, cujo sacrifício, nas circunstâncias, não era razoável exigir-se.

Perigo atual diz respeito a dano presente e imediato, ou seja, aquele que está prestes a ocorrer, não servindo o dano incerto ou já consumado. Além disso, se o dano tiver sido provocado pelo agente dolosamente, não se fala em estado de necessidade. Portanto, se a situação de perigo tiver sido provocada culposamente pelo indivíduo, pode alegar estado de necessidade. ${ }^{225}$

Somente a situação de fato concreta é que poderá apresentar se o sacrifício a direito de outrem podia ser sacrificado ou não.

Por outro lado, o sacrifício do bem alheio só ocorre quando for inevitável para salvar bem próprio ou de terceiro, ou seja, a lesão deve ser o único meio para afastar o perigo, que de outro modo não podia ser evitado. ${ }^{226}$

É importante salientar que o estado de necessidade não pode ser alegado por quem tinha o dever legal de enfrentar o perigo (Código Penal, art. 24, $\S 1^{\circ}$ ).

Além de tais requisitos objetivos, já foi dito que é preciso que o agente tenha consciência de que age em estado de necessidade (requisito subjetivo).

Em caso de instauração de inquérito policial, caso reste caracterizado o estado de necessidade, não se fala em crime, de modo que é possível o trancamento a pedido do

\footnotetext{
FRAGOSO, Heleno Cláudio. Lições de direito penal. 15 a ed. rev. atual. Rio de Janeiro: Forense, 1994, p. 189.

$225 \quad$ Ibidem, p. 190.

226 Ibidem, mesma página.
} 
investigado, salvo se ficar demonstrado que o agente excedeu, dolosa ou culposamente, a dirimente (Código Penal, art. 23, parágrafo único).

\subsubsection{Legítima defesa}

O Código Penal define a legítima defesa como a conduta de quem, "usando moderadamente dos meios necessários, repele injusta agressão, atual ou iminente, a direito seu ou de outrem" (art. 25).

Portanto, os requisitos objetivos são apontados no texto: uso moderado dos meios necessários para repelir injusta agressão, esta atual ou iminente, contra direito do agente ou de terceira pessoa.

A agressão consiste em conduta humana - portanto, não há legítima defesa contra ataque de animais - que pode causar lesão ou pôr em perigo um bem jurídico. Pode haver agressão por omissão quando o agente tem o dever de impedir o resultado. ${ }^{227}$

É injusta a agressão quando contrária ao direito, ou seja, quando não autorizada pela lei e que não obriga o agredido a suportá-la.

Além de injusta, a agressão deve ser atual ou iminente, ou seja, deve estar ocorrendo no momento em que o agente atua em legítima defesa ou prestes a ocorrer.

O meio utilizado para a legítima defesa deve ser necessário e moderado, isto é, deve ser o meio disponível para o agredido repelir a injusta agressão.

Assim como no estado de necessidade e nas demais hipóteses de exclusão da antijuridicidade, deve o agente ter consciência de atuar em legítima defesa (requisito objetivo).

Quando plenamente caracterizada a legítima defesa pelos elementos colhidos durante a tramitação do inquérito, é possível seu trancamento antes de seu encerramento, $227 \quad$ Ibidem, p. 186. 
salvo se ficar demonstrado que o imputado agiu com excesso doloso ou culposo (Código Penal, art. 23, parágrafo único).

\subsection{3}

\section{Exercício regular de direito}

Não é ilícita e, portanto, não há crime, a conduta do agente que pratica o ato em exercício regular de direito (Código Penal, art. 23, III).

Atua em exercício regular de direito aquele que "exercita uma faculdade de acordo com o direito". 228

É o caso do advogado que, ao defender os interesses de seu cliente, acaba por causar ofensa em juízo na discussão da causa, não constituindo esta conduta injúria ou difamação punível (Código Penal, art. 141, I) desde que não haja excesso doloso (Código Penal, art. 23, parágrafo único).

Da mesma forma, as intervenções cirúrgicas ou os danos à integridade corporal decorrentes de esportes violentos são casos de exercício regular de direito.

Demonstrada no inquérito policial a existência dessa causa de exclusão da antijuridicidade, possível seu trancamento, uma vez que não há crime.

\subsection{4}

\section{Estrito cumprimento do dever legal}

Quando o fato típico tiver sido praticado em estrito cumprimento do dever legal não há crime (Código Penal, art. 23, III), salvo se houver excesso doloso ou culposo (Código Penal, art. 23, parágrafo único).

$228 \quad$ PRADO, Luiz Regis. Curso de direito penal brasileiro. $9^{\text {a }}$ ed. rev. amp. atual. São Paulo: Revista dos Tribunais, 2010, v. 1, p. 368. 
Age em estrito cumprimento do dever legal quem atua por imposição legal, ou seja, por força de determinação existente no ordenamento jurídico. Assim, o ato surge de dever legal, não bastando o interesse moral, social ou religioso.

Como exemplos, podemos citar a invasão da residência pelo oficial de justiça para cumprir mandado de despejo ou para cumprir mandado de prisão. Em tais casos, o agente executou sua função por dever legal, ou seja, por imposição da lei.

Assim como nas demais hipóteses de exclusão de antijuridicidade, possível o trancamento de inquérito policial instaurado para apurar fato que não pode ser considerado crime justamente em razão de o fato típico não ser antijurídico, não havendo crime a apurar (Código Penal, art. 23).

Foi dito nesse estudo que ocorrendo um fato descrito na norma penal incriminadora e não havendo uma causa de exclusão da antijuridicidade, estará caracterizado o crime. Assim, o crime é o fato típico e antijurídico.

Porém, ainda que determinada conduta seja típica e antijurídica de modo que tenha ocorrido um crime, para que seja imposta um pena, necessária a reprovabilidade dessa conduta. Nisso consiste a culpabilidade, ou seja, na reprovabilidade da conduta típica e antijurídica.

O primeiro elemento da culpabilidade é a capacidade de autodeterminação. A esse elemento se dá o nome de imputabilidade.

Além da imputabilidade, é preciso que o sujeito tenha consciência do caráter ilícito do fato que praticou e atue de acordo com esse conhecimento. É a potencial consciência da ilicitude.

Por fim, a reprovabilidade da conduta exige que seja possível outra atitude por parte do agente, ou seja, que fosse possível ao sujeito comportamento diverso daquele que 
praticou ao realizar o fato típico e antijurídico. É a denominada exigibilidade de conduta diversa. ${ }^{229}$

Ausente qualquer desses elementos, não se fala em culpabilidade, de modo que, apesar de típica e antijurídica a conduta, não é ela reprovável, razão pela qual não se impõe pena.

Assim, exclui-se a culpabilidade pela inimputabilidade, pela inconsciência da ilicitude e pela inexigibilidade de conduta diversa.

Passemos à análise das causas de exclusão da culpabilidade, ressaltando que nem todas elas interessam ao trancamento do inquérito policial, como veremos adiante, onde somente trataremos das hipóteses que impeçam o normal prosseguimento dos atos investigativos.

\subsection{1}

\section{Inimputabilidade}

Os casos de inimputabilidade são tratados pelos artigos 26 a 28 do Código Penal. São eles: doença mental, desenvolvimento mental incompleto ou retardado (art. 26 do Código Penal), menoridade (art. 27 do Código Penal) e embriaguez fortuita completa (art. 28, $\S 1^{\text {o }}$ do Código Penal).

As duas primeiras hipóteses não interessam ao estudo do trancamento do inquérito policial, haja vista que no caso de doença mental, desenvolvimento mental incompleto ou retardado não se impõe pena, mas medida de segurança (artigos 96 e 97 do Código Penal), motivo pelo qual é necessário o inquérito e respectivo processo para aplicação dessa medida, ao passo que em caso de menoridade, praticado fato típico e antijurídico por criança ou adolescente, denominado ato infracional, impõe-se ao infrator alguma das medidas socioeducativas previstas no Estatuto da Criança e do Adolescente (Lei n. 8.069, de 13-7-1990), o que será determinado pelo juízo da infância e juventude competente. 
Por outro lado, quando ficar plenamente demonstrado no inquérito policial que o agente praticou o crime em estado de embriaguez completa proveniente de caso fortuito ou força maior, tornado-o, ao tempo da ação ou da omissão, inteiramente incapaz de entender o caráter ilícito do fato ou de determinar-se de acordo com esse entendimento, não se impõe pena (Código Penal, art. 28, $\S 1^{\circ}$ ), razão pela qual pode haver o trancamento do inquérito policial, uma vez que a ação penal se torna totalmente desnecessária ante sua inutilidade. Na legislação especial (Lei n. 11.343, de 23-8-2006) também se exclui a culpabilidade do agente que, em razão de dependência, ou sob o efeito, proveniente de caso fortuito ou força maior, de droga, era, ao tempo da ação ou da omissão, qualquer que tenha sido a infração penal praticada, inteiramente incapaz de entender o caráter ilícito do fato ou de determinar-se de acordo com esse entendimento, mas nesse caso o juiz poderá determinar o encaminhamento do agente a tratamento médico adequado (art. 45 e parágrafo único) mediante internação ou tratamento ambulatorial, de modo que há necessidade da ação penal para tal imposição, não se falando em trancamento do inquérito.

No caso de embriaguez fortuita completa, não há razão lógica para a continuidade do inquérito policial se ficar plenamente demonstrada tal situação se mesmo após sua conclusão e encaminhamento a juízo nenhuma sanção vai ser imposta após o término da ação penal.

Nunca é demais lembrar que a máquina estatal demanda recursos para prover a prestação jurisdicional e um processo judicial inútil, ante conclusão já alcançada no inquérito policial, só acabaria por aumentar esses custos com a tramitação de ação penal que, ao final, de nada serviria, uma vez que nenhuma pena é aplicável ao autor do fato, isso sem falar nos demais gastos que envolvem uma ação penal, como honorários de advogado, custas judiciais, gasto com transporte para deslocamento ao local da realização da instrução, com perda de tempo e recursos públicos e privados.

Isso não significa que a ação penal só tenha razão de ser se alguma sanção for aplicável ao autor do fato. Não. Não é somente para isso que serve esse instrumento estatal. Mas uma vez existentes elementos mais do que suficientes que demonstrem que o agente praticou o ilícito em estado de embriaguez fortuita completa, não há razão para o seguimento do inquérito policial nem tampouco para a tramitação de ação penal sem qualquer utilidade ante o conhecimento da impossibilidade de aplicação de sanção. 
No entanto, somente se houver elementos seguros, firmes e incontestáveis sobre a embriaguez completa fortuita é que será possível o trancamento do inquérito policial, uma vez que, se pairar sobre essa causa de exclusão da culpabilidade qualquer dúvida, nesse caso será necessária a conclusão do inquérito policial e posterior ação penal para melhor apuração do ocorrido no caso concreto.

Além disso, a embriaguez voluntária ou culposa, pelo álcool ou substância de efeitos análogos, bem como a emoção e a paixão não excluem a imputabilidade (Código Penal, art. 28) e, por consequência, não excluem a culpabilidade, não se falando, nesses casos, em trancamento do inquérito policial.

\subsubsection{Inconsciência da ilicitude}

A potencial consciência da ilicitude se caracteriza pelo conhecimento do agente de atuar de forma contrária ao direito.

Contudo, se o autor do fato, por erro, acreditar que age conforme o direito, sua conduta não pode ser considerada reprovável, razão pela qual não se fala em culpabilidade. A isso se dá o nome de erro de proibição, ou seja, o agente, por erro, supõe não estar agindo contrariamente ao direito. As hipóteses de erro de proibição são o desconhecimento da lei, erro sobre a ilicitude do fato, erro sobre existência de causa de justificação e erro sobre situação de fato que, se existisse, tornaria a ação legítima ${ }^{230}$.

O desconhecimento da lei é inescusável, ou seja, não é aceito pela lei o argumento de ignorância de seu conteúdo para fins de afastamento da culpabilidade (Código Penal, art. 21), embora sirva de circunstância atenuante (Código Penal, art. 65, II). Por isso, nessa hipótese não se fala em trancamento do inquérito policial.

O erro sobre a ilicitude do fato só afasta a culpabilidade se inevitável (Código Penal, art. 21), ou seja, se escusável, invencível, desculpável, que ocorre não por 
negligência ou falta de atenção, mas por circunstância que impede mesmo as pessoas conscientes e capazes de compreender a ilicitude do fato. Quando o erro sobre a ilicitude do fato for inevitável, é isento de pena o agente por ausência de culpabilidade (Código Penal, art. 21, $1^{\mathrm{a}}$ parte). Quando evitável, impõe-se pena, mas o juiz poderá diminuí-la de 1/6 a 1/3 (Código Penal, art. 21, $2^{\mathrm{a}}$ parte). Considera-se evitável o erro quando o agente atua ou se omite sem a consciência da ilicitude do fato, quando the era possível, nas circunstâncias, ter ou atingir essa consciência.

Ao trancamento do inquérito policial interessa somente o erro sobre a ilicitude do fato inevitável ante a previsão de isenção de pena por ausência de culpabilidade. Como dito alhures, a absoluta inutilidade do processo judicial, que acabará por não impor qualquer sanção ao agente, aliada aos custos demandados para a prestação jurisdicional, quando há demonstração firme e segura no sentido de ter atuado o agente sob tal excludente de culpabilidade, possibilita o trancamento do inquérito policial. Mas vale aqui, mais uma vez, a ressalva: somente quando for irrefutável a ocorrência dessa causa de exclusão da culpabilidade é que será possível o trancamento, pois se houver qualquer dúvida, faz-se necessária a conclusão do inquérito e o ajuizamento da ação penal.

O erro sobre a existência de uma causa de justificação é aquele em que o autor do fato supõe existir para sua conduta uma causa de exclusão de antijuridicidade, o que nada mais é do que o erro inescusável, irrelevante, que não afasta a culpabilidade (Código Penal, art. 21) e, portanto, não serve de fundamento para trancamento de inquérito policial.

Por fim, o erro sobre situação de fato que, se existisse, tornaria a ação legítima ocorre quando o agente supõe atuar de forma lícita acreditando estar acobertado por uma causa de exclusão de antijuridicidade. É o que ocorre quando o agente se depara com alguém que o ameaçara de morte e que coloca a mão no bolso. Supondo que vá tirar uma arma, atira na vítima achando que atua em legítima defesa quando, na verdade, a vítima ia apenas pegar seus documentos. O exemplo cita a hipótese de legítima defesa putativa. Concordamos com Heleno Fragoso ao interpretar essa atuação como erro de proibição, não como erro sobre os elementos do tipo, visto que o autor do fato erra sobre a ilicitude de seu comportamento, tendo consciência da conduta típica, mas supõe erroneamente que atua amparado por causa de exclusão de antijuridicidade, de modo que não se exclui a 
tipicidade, pois dolo há, mas a reprovabilidade da ação e, por consequência, a culpabilidade. $^{231}$

Se por erro plenamente justificado pelas circunstâncias o autor do fato agir por supor situação de fato que, se existisse, tornaria a ação legítima, fica isento de pena (Código Penal, art. 20, $\S 1^{\mathrm{o}}, 1^{\mathrm{a}}$ parte). Mas se o erro deriva de culpa e o fato é punível como crime culposo, não há isenção de pena (Código Penal, art. 20, $\S 1^{\mathrm{o}}, 2^{\mathrm{a}}$ parte). A primeira hipótese permite o trancamento do inquérito policial por erro de proibição, o que não ocorre com a segunda, que impõe ação penal posterior ao inquérito concluído.

Difere o erro de proibição do erro de tipo. No primeiro, há erro sobre a ilicitude do fato, ao passo que, no segundo, exclui-se o dolo e o erro recai sobre os elementos constitutivos do tipo, mas o fato é punível como crime culposo, se previsto em lei (Código Penal, art. 20).

\section{Inexigibilidade de conduta diversa}

Foi dito no transcorrer deste estudo que a culpabilidade tem relação com a reprovabilidade da conduta. Casos há em que situações ou condutas são realizadas quando não se pode exigir comportamento diverso do agente. Assim, se o agente praticou fato típico e antijurídico, mas atuou por razões excepcionais, onde não se podia dele exigir outro comportamento, não se pode considerar reprovável sua conduta, de modo que excluída resta a culpabilidade.

Heleno Fragoso e Damásio de Jesus divergem sobre a existência de causa supralegal de exclusão da culpabilidade pela inexigibilidade de conduta diversa. $\mathrm{O}$ primeiro sustenta não funcionar essa hipótese como causa supralegal sob o argumento de que isso equivaleria ao abandono de todo critério objetivo para exclusão da reprovabilidade pessoal ${ }^{232}$. O segundo, ao revés, e ao nosso ver com razão, alega que o legislador, por mais previdente que seja, não pode prever todos os casos em que a inexigibilidade de conduta diversa deve excluir a culpabilidade. Segundo ele, não seria

\begin{tabular}{ll}
\hline 231 & Ibidem, p. 208-209. \\
232 & Ibidem, p. 210.
\end{tabular}


justo condenar alguém só porque o fato não foi previsto pelo legislador como hipótese de inexigibilidade de conduta diversa, quando o que importa é atender ao princípio da não exigibilidade de comportamento lícito, até porque não há pena sem culpa. Isso seria possível pelo processo de integração, com aplicação da regra prevista no art. $4^{\circ}$ da Lei de Introdução ao Código Civil, seja pelos costumes, seja pelos princípios gerais de direito $^{233}$.

De todo modo, os casos de inexigibilidade de conduta diversa previstos no ordenamento são a coação moral irresistível e algumas situações de obediência hierárquica.

Difere a coação física irresistível, onde não há ação, da coação moral irresistível, quando ocorre a ação, mas se exclui a culpabilidade por não ser exigível conduta diversa. ${ }^{234}$

A coação moral irresistível normalmente decorre de ameaça, expressa ou tácita, seja de causar um mal futuro, seja de continuar a violência já iniciada. É evidente que esse mal deve ser sério, considerável para a pessoa ameaçada. Além disso, a ameaça deve ser dirigida ao agente que por coação comete o crime, mas pode ter como vítima terceira pessoa. Pode-se citar como exemplo pessoa que aponta arma de fogo para a cabeça do filho do agente que é induzido a ministrar veneno na bebida da vítima, sob ameaça de matá-lo caso assim não proceda. Por outro lado, se a coação é resistível não se exclui a culpabilidade, mas ela será considerada circunstância atenuante pelo juiz na dosimetria da pena (Código Penal, art. 65, III, c).

Se o fato for praticado por coação moral irresistível, considera-se o autor da infração aquele que efetuou a ameaça, excluindo-se a culpabilidade do executor do crime (Código Penal, art. 22).

A obediência hierárquica, para excluir a culpabilidade, demanda o atendimento de alguns requisitos.

A relação de subordinação entre o superior hierárquico e o executor da ordem deve ser de direito público, não se cogitando da relação entre empregado e empregador nem

\footnotetext{
233 JESUS, Damásio Evangelista de. Direito penal: parte geral. 32 ed. rev. atual. São Paulo: Saraiva, 2011, v. 1, p. 527-528.

234 FRAGOSO, Heleno Cláudio. Lições de direito penal. 15 ed. rev. atual. Rio de Janeiro: Forense, 1994, p. 210-211.
} 
tampouco da relação de parentesco. Além disso, a ordem não deve ser manifestamente ilegal, visto que, se o for, o executor responde pelo crime em concurso com seu superior hierárquico. Por fim, deve o executor limitar-se ao cumprimento estrito da ordem do superior, sob pena de incorrer em excesso punível (Código Penal, art. 22).

A inexigibilidade de conduta diversa na obediência hierárquica decorre da subordinação a que o agente está submetido. Assim como na coação moral irresistível, na obediência hierárquica a ordem não manifestamente ilegal pune-se o autor da ordem e exclui-se a culpabilidade do subordinado (Código Penal, art. 22).

Nos casos de obediência hierárquica, coação moral irresistível ou mesmo em hipótese de causa supralegal de inexigibilidade de conduta diversa, havendo provas seguras, firmes e coerentes no inquérito policial a demonstrar tais situações, possível o trancamento do inquérito policial instaurado contra o executor da ordem ou vítima da coação, nada impedindo a instauração de novo inquérito policial, mas para apurar a conduta do superior hierárquico ou daquele que praticou a coação moral.

Uma vez ocorrida a infração penal, nasce para o Estado o direito de punir seu autor, com a imposição de uma pena ao transgressor da norma penal. Esse direito de punir sai do plano abstrato para o concreto, ou seja, de direito potencial para o efetivo. ${ }^{235}$

Contudo, há situações em que a punibilidade é extinta, desaparecendo esse direito do Estado de punir o autor do crime, ou seja, a possibilidade de imposição de pena. ${ }^{236}$

O artigo 107 do Código Penal enumera essas hipóteses, embora haja outras também previstas no corpo do Código Penal, mas em outros dispositivos, tais como o cumprimento de pena no estrangeiro por crime lá praticado, quando for possível a aplicação da lei penal

\footnotetext{
235 TOURINHO FILHO, Fernando da Costa. Processo penal. $33^{\mathrm{a}}$ ed. rev. atual. São Paulo: Saraiva, 2011, v. 1, p. 626.

236 FRAGOSO, Heleno Cláudio. Lições de direito penal. 15 ed. rev. atual. Rio de Janeiro: Forense, 1994, p. 399.
} 
brasileira (Código Penal, art. $7^{\circ}, \S 2^{\circ}, d$ ) ou quando houver o ressarcimento do dano no peculato culposo (Código Penal, art. 312, $\S 3^{\circ}$, primeira parte).

Destarte, o rol do artigo 107 do Código Penal não é exaustivo. ${ }^{237}$ Tourinho Filho aponta a hipótese de extinção da punibilidade em caso de suspensão condicional do processo sem revogação ${ }^{238}$ (Lei n. 9.099, de 26-9-1995, art. 89, § 5).

Vejamos cada uma dessas hipóteses indicadas no artigo 107 do Código Penal e em outros dispositivos.

\subsection{1}

\section{Morte do agente}

A morte do agente extingue a punibilidade (Código Penal, art. 107, I), uma vez que a pena pela prática de um crime não pode passar da pessoa do seu autor para outras pessoas (Constituição Federal, art. 5 XLV, primeira parte).

A morte do investigado se prova com a certidão de óbito (Código de Processo Penal, art. 62). Também se presume legalmente a morte em caso de declaração judicial de ausência (art. 24, $\S 1^{\circ}$ do Código de Processo Penal). Há, contudo, quem entenda que a declaração judicial de ausência não extinga a punibilidade. ${ }^{239}$

Caso a autoridade policial tomar conhecimento da morte do investigado, deverá comunicar tal fato no inquérito policial e remetê-lo a juízo, onde o juiz, após ouvir o Ministério Público, deverá declarar extinta a punibilidade.

Caso o juiz não declare extinta a punibilidade, ainda que diante da notícia da morte do investigado e perante a certidão de óbito, determinando o retorno dos autos à repartição policial para que continue a investigar o crime, entendemos que é possível não só ao Ministério Público interpor correição parcial contra essa decisão para que a superior

\footnotetext{
237 GARCIA, Basileu. Instituições de direito penal. In: Série clássicos jurídicos. $7^{\mathrm{a}}$ ed. rev. atual. São Paulo: Saraiva - Fundação Getúlio Vargas, 2008, v. I, tomo II, p. 326.

TOURINHO FILHO, Fernando da Costa. Processo penal. $33^{\mathrm{a}}$ ed. rev. atual. São Paulo: Saraiva, 2011, v. 1, p. 628.

MIRABETE, Julio Fabbrini; FABBRINI, Renato N. Manual de direito penal: parte geral. $26^{\mathrm{a}}$ ed. rev. atual. São Paulo: Atlas, 2010, v. 1, p. 371.
} 
instância determine o trancamento do inquérito policial, mas também ao cônjuge, ascendente, descendente ou irmão do investigado (Código de Processo Penal, art. 24, $\S 1^{\circ}$ por analogia), que teriam legitimidade para interpor habeas corpus perante a superior instância, com fundamento no art. 648, VII do Código de Processo Penal.

Pela mesma razão, se a autoridade policial tiver notícia da morte do investigado e não comunicar esse fato à autoridade judicial e ao Ministério Público, prosseguindo nas investigações, o Ministério Público e as pessoas apontadas no art. 24, $\S 1^{\circ}$ do Código de Processo Penal poderão requerer ao juiz o trancamento do inquérito policial.

Caso o trancamento do inquérito policial seja decretado com fundamento na morte do investigado com base em certidão de óbito falsa e ocorrer o trânsito em julgado dessa decisão, não será possível a abertura de novo inquérito policial para investigar o fato que se apurava no inquérito trancado, visto que não existe revisão criminal contra os acusados da prática de $\operatorname{crimes}^{240}$ (Código de Processo Penal, art. 621). Será possível, somente, a abertura de inquérito policial para a apuração da falsificação de documento público (Código Penal, art. 297).

Por outro lado, a morte é causa pessoal de extinção da punibilidade, de modo que não se estende a terceiros também investigados, razão pela qual não haverá trancamento do inquérito policial contra os coautores do crime investigado no inquérito.

\subsection{2}

\section{Anistia}

A anistia, a graça e o indulto são formas de indulgência concedidas por órgãos alheios ao Poder Judiciário, que se baseiam em razões de conveniência política ou por espírito de humanidade, acarretando o desaparecimento do crime praticado e extinguindo a pena. $^{241}$

A anistia se refere ao fato delituoso e não pode ser recusada, embora seja possível a estipulação de condições a serem satisfeitas pelos favorecidos.

\footnotetext{
$240 \quad$ Ibidem, mesma página.

241 FRAGOSO, Heleno Cláudio. Lições de direito penal. $15^{\mathrm{a}}$ ed. rev. atual. Rio de Janeiro: Forense, 1994, p. 401.
} 
A concessão de anistia é de competência do Congresso Nacional, que a declara por meio de lei (Constituição Federal, art. 48, VIII). Uma vez concedida a anistia, não poderá ser revogada.

A anistia pode ser própria, quando concedida antes da condenação, ou imprópria, se concedida após a condenação. Também pode ser geral (plena) ou parcial (restrita). A primeira beneficia todos os criminosos autores de crimes, de forma indistinta. A segunda, somente determinadas pessoas (por exemplo, os primários) ou os autores de determinados crimes. Poderá, ainda, ser condicionada, quando serão impostas condições para o benefício, ou incondicionada, quando nada for estipulado para se beneficiar de seus termos.

A Constituição Federal impede a concessão de anistia aos crimes de tortura, tráfico ilícito de entorpecentes, terrorismo e aos denominados hediondos ( $\operatorname{art} .5^{\circ}$, XLIII), que são indicados pela Lei n. 8.072, de 25-7-1990.

Enquanto a anistia declara extinto não só o crime, mas também a punibilidade, a graça e o indulto extinguem tão-somente a punibilidade. A anistia pode ser concedida antes ou depois da condenação. A graça e o indulto só podem ser concedidos depois da condenação. Além disso, a competência para a concessão de graça e indulto é do Presidente da República (Constituição Federal, art. 84, XII).

Ora, se a graça e o indulto só podem ser concedidos depois da condenação, não se fala em trancamento do inquérito policial por meio deles, uma vez que nessa fase da persecução penal não há imposição de penas, mas somente investigação da autoria e materialidade do delito.

Assim, não se pode fundamentar pedido de trancamento de inquérito policial com base em concessão de graça e indulto, mas somente em hipótese de anistia própria, ou seja, aquela concedida antes da condenação e enquanto estiver em tramitação o inquérito policial. 
Caso seja promulgada lei pelo Congresso Nacional concedendo anistia própria e a autoridade policial continue a proceder as investigações, será possível ao investigado pedir à autoridade judiciária competente o trancamento do inquérito policial.

\subsubsection{Retroatividade de lei que não considera mais a conduta como criminosa}

A terceira causa de extinção de punibilidade é a retroatividade de lei que não mais considera o fato como criminoso (Código Penal, art. 107, III). Essa hipótese é conhecida como abolitio criminis.

$\mathrm{O}$ art. $1^{\circ}$ do Código Penal dispõe que não há crime sem lei anterior que o defina, ou seja, somente aquelas condutas definidas no tipo penal serão consideradas crime. $\mathrm{O}$ fato que não se enquadrar na norma penal será considerado atípico, ou seja, não pode ser considerado como criminoso.

Esse dispositivo traz implícita a regra geral da irretroatividade das leis penais. ${ }^{242}$ Aliás, o art. $5^{\circ}, \mathrm{XL}$ da Constituição Federal dispõe que a lei penal não retroagirá, salvo para beneficiar o réu.

Por sua vez, o art. $2^{\circ}$ do Código Penal dispõe que ninguém pode ser punido por fato que lei posterior deixa de considerar crime. Esse dispositivo excetua a regra geral da irretroatividade da lei penal do art. $1^{\circ}$, permitindo a retroatividade benéfica ${ }^{243}$, o que reforça o disposto no art. $5^{\circ}$, XL da Constituição Federal.

Nas palavras de Frederico Marques "com a abolitio criminis, a lei nova exclui do ilícito punível fato anteriormente considerado crime"244 Essa lei nova, ao abolir a conduta anteriormente considerada criminosa, retroage para alcançar toda relevância jurídico-penal de fatos que na lei anterior eram considerados como crime. ${ }^{245}$

\footnotetext{
$\overline{242}$ GARCIA, Basileu. Instituições de Direito Penal. $4^{\mathrm{a}}$ ed. São Paulo: Max Limonad, 1978, v. I, tomo I, p. 146. Ibidem, p. 147.

MARQUES, José Frederico. Tratado de direito penal: propedêutica penal e norma penal. $1^{a}$ ed. atual. Campinas: Bookseller, 1997, v. I, p. 251. Ibidem, p. 252.
} 
Assim, a conjugação dos artigos $1^{\circ}, 2^{\circ}$ e 107 , III, todos do Código Penal, permite concluir que se lei posterior é promulgada e deixa de considerar criminoso o fato anteriormente definido como crime, caso haja inquérito policial em andamento para apurar uma conduta considerada anteriormente criminosa, deverá a autoridade policial remeter os autos a juízo para que seja declarada extinta a punibilidade.

Caso a autoridade policial não tome essa providência ou, se tomar, não for declarada extinta a punibilidade pela autoridade judiciária após a oitiva do Ministério Público, poderá o investigado solicitar ao órgão jurisdicional competente o trancamento do inquérito policial e a consequente decretação da extinção da punibilidade com fundamento nos artigos acima apontados.

É a hipótese do antigo crime de adultério. O art. 240 do Código Penal foi revogado pela Lei n. 11.106, de 28-3-2005. Caso seja instaurado inquérito policial para apuração desse fato (adultério), o investigado poderá requerer seu trancamento, haja vista que lei posterior revogou o art. 240 do Código Penal, deixando de considerar esse fato como crime, de modo que não poderá ser instaurado inquérito policial, tendo em vista que ocorreu a denominada abolitio criminis.

\subsubsection{Prescrição}

A prescrição ocorre quando um direito deixa de ser exercitado no prazo estipulado pela lei, ou seja, ela ocorre em razão do decurso do tempo.

No caso do Direito Penal, a prescrição extingue o direito do Estado exercer o jus puniendi (pretensão punitiva) ou o direito à execução da pena imposta. Daí por que se fala em duas espécies de prescrição: prescrição da pretensão punitiva, que ocorre antes de a sentença penal condenatória transitar em julgado, e a prescrição da pretensão executória, que ocorre após a condenação definitiva e faz desaparecer o direito do Estado de executar a pena imposta.

Somente interessa ao presente estudo a prescrição da pretensão punitiva e mesmo antes da propositura da ação penal, visto que estamos tratando de inquérito policial. Além 
disso, a recente reforma que mudou em parte o instituto da prescrição operada pela Lei $n$. 12.234, de 5-5-2010, que extinguiu a denominada prescrição retroativa, não tem relevância para a questão do trancamento, visto que aborda esse instituto na fase judicial. O estudo aprofundado dos prazos, termo inicial, causas de suspensão ou de interrupção da prescrição também são estranhos ao objeto do estudo.

Há crimes, porém, que são imprescritíveis, como o crime de racismo (Constituição Federal, art. 5 XLII - Lei n. 7.776, de 5-1-1989, alterada pela Lei n. 9.459, de 15-5-1997) e a ação de grupos armados, civis e militares, contra a ordem constitucional e o Estado Democrático (Constituição Federal, art. 5, XLIV). Nesses casos, não se fala em trancamento do inquérito por força da prescrição.

A prescrição é irrenunciável. ${ }^{246}$

Suponha-se a ocorrência de um crime de homicídio simples praticado em $1^{\mathrm{o}}$ de janeiro de 1980. Esse crime é de ação penal pública incondicionada, portanto, pode haver a instauração de inquérito de ofício pela autoridade policial (art. $5^{\circ}$, I do Código de Processo Penal). Imagine-se que é dado conhecimento de tal crime à autoridade policial somente em $1^{\mathrm{o}}$ de janeiro de 2012. Passaram-se trinta e dois anos. O prazo da prescrição da pretensão punitiva para esse delito é de vinte anos, visto que a pena em abstrato para o homicídio simples é de reclusão de seis a vinte anos (art. 109, I e 121, caput do Código Penal). Assim, já ocorrera a prescrição.

Na hipótese acima, é evidente que a instauração de inquérito pela autoridade policial causará constrangimento ilegal ao indiciado - ou investigado se ainda não houve tempo suficiente para o indiciamento -, visto que o crime já está prescrito e não há necessidade de se apurar autoria e materialidade de um crime que sequer pode ser punido justamente em razão de sua prescrição. Se ainda assim, a autoridade policial instaurar o inquérito, poderá o interessado requerer ao juiz competente seu trancamento, com imediata cessação das investigações, com o fim de cessar o constrangimento ilegal a que está sendo submetido.

246 JESUS, Damásio Evangelista de. Prescrição penal. $19^{\mathrm{a}}$ ed. São Paulo: Saraiva, 2010, p.43. 


\subsubsection{Ausência de representação nos crimes de ação penal condicionada}

Nos crimes de ação penal pública condicionada, o inquérito policial não pode ter início sem a representação do ofendido ou de quem o represente (art. $5^{\circ}, \S 4^{\circ}$ do Código de Processo Penal). Se a autoridade policial instaurar inquérito sem a representação do ofendido ou de quem o represente, claro está que o investigado estará passando por constrangimento ilegal, visto que nem mesmo o ofendido ou seu representante quiseram que a investigação tivesse início para eventual e posterior punição do investigado. Diante disso, caberá o trancamento do inquérito instaurado irregularmente.

\subsubsection{Ausência de requerimento do ofendido ou de seu representante nos crimes de ação privada}

A situação é idêntica no caso de crimes de ação penal privada. Nessa hipótese, o inquérito policial não poderá ser iniciado sem pedido de quem tenha qualidade para intentar a ação penal (art. $5^{\circ}, \S 5^{\circ}$ do Código de Processo Penal). Instaurado o inquérito pela autoridade policial sem esse pedido, poderá ser ele trancado, com encerramento das investigações.

1.20.7

\section{Decadência}

A decadência acarreta a perda do direito pela ação do tempo. É causa de extinção da punibilidade (Código Penal, art.107, IV).

A decadência acarreta a perda do direito de queixa - na ação penal privada - ou de representação - na ação penal pública condicionada - caso o ofendido ou seu representante não o exerça dentro do prazo de seis meses contado do dia em que veio a saber quem é o autor do crime ou, no caso de ação penal privada subsidiária da pública, do dia em que se esgotou o prazo para o oferecimento da denúncia pelo Ministério Público (Código Penal, art. 103 e Código de Processo Penal, art. 38). 
A decadência se refere ao direito de o ofendido ou se representante agirem diretamente, no caso de ação penal privada, e indiretamente, na hipótese de ação penal pública condicionada à representação, de modo que ela incide sobre um direito instrumental, alcançando também o direito material. ${ }^{247}$

Quando decorrido o prazo de seis meses da ciência do ofendido ou de seu representante de quem foi o autor da infração penal, nos crimes de ação penal privada, ocorrerá a decadência do direito de apresentar queixa (art. 38 do Código de Processo Penal). Na hipótese de a autoridade policial instaurar inquérito policial a pedido do ofendido ou de seu representante legal após o decurso desse prazo, como não há interrupção de sua contagem com a instauração do inquérito, é evidente que sua instauração não tem o menor sentido, visto que sequer poderá ser exercido pelo ofendido ou seu representante o direito de queixa em virtude da decadência. Se ainda assim instaurálo, poderá o investigado requerer seu trancamento a fim de ser encerrada a investigação.

A presente hipótese diverge das duas anteriores. Naquelas situações, a autoridade policial instaura inquérito policial sem requerimento de quem tenha qualidade para intentar a ação penal privada ou a representação do ofendido ou de seu representante nos crimes de ação penal pública condicionada.

No caso da decadência, há o requerimento de abertura do inquérito por aquele que tem qualidade para intentar ação penal privada e há representação pelo ofendido ou seu representante na ação penal pública condicionada, só que já houve o decurso do prazo de seis meses para tais providências, de modo que o inquérito não poderá mais ser instaurado e, se o for, poderá ser trancado a pedido do investigado.

Importante ressaltar que o prazo de decadência não se interrompe nem se suspende.

As situações trazidas por estas últimas três hipóteses demonstram a importância do estudo do início do inquérito policial conforme anteriormente havíamos esclarecido, haja vista que têm relação direta com a questão de seu trancamento decorrente da ausência dos requisitos legais.

247 NORONHA, E. Magalhães. Direito penal. Atualizado por Adalberto José Q. T. de Camargo Aranha. $31^{\text {a }}$ ed. São Paulo: Saraiva, 1995, v. 1, p. 345. 
Por fim, o artigo 107, IV do Código Penal, aponta como causa extintiva da punibilidade a perempção ao lado da prescrição e da decadência já estudados. Este instituto, porém, não interessa ao estudo do trancamento do inquérito policial, uma vez que se refere à fase judicial da ação penal privada, já que ocorre quando, iniciada a ação penal, extingue-se o processo por inércia do querelante. Assim, seu estudo não tem relevância para o objeto de nosso estudo.

\subsection{0 .8}

\section{Renúncia}

Da mesma forma, se houver renúncia ao direito de queixa (art. 49 e art. 50 do Código de Processo Penal), é evidente que a ação penal privada não será instaurada. Ora, se isso ocorrer e, ainda assim, for instaurado inquérito policial, evidente o constrangimento ilegal a que estará sujeito o investigado, visto que a renúncia é irretratável (art. 104 do Código Penal). Em vista disso, é possível o trancamento do inquérito policial instaurado indevidamente.

A renúncia ao direito de queixa nada mais é do que a manifestação da vítima ou de seu representante legal no sentido de não exercer tal direito. É, pois, a abdicação do direito de promover a ação penal privada. ${ }^{248}$

Ela pode ser expressa, quando constar de declaração assinada pelo ofendido ou seu representante, com poderes especiais, ou tácita, que resulta da prática de ato incompatível com a vontade de exercer o direito de queixa, não se considerando renúncia tácita $o$ recebimento da indenização decorrente do dano causado pelo crime (Código Penal, art. 104 e parágrafo único).

Caso haja renúncia ao direito de queixa em relação a um dos autores do crime, a todos se estende, visto que a ação penal privada é indivisível, obrigando o processo contra todos os autores e eventuais partícipes (Código de Processo Penal, artigos 48 e 49).

248 JESUS, Damásio Evangelista de. Direito penal: parte geral. 32 ed. rev. atual. São Paulo: Saraiva, 2011, v. 1, p.741. 
Por outro lado, se houve mais de um ofendido, a renúncia de um deles não prejudica o direito dos demais à ação penal privada.

Suponha-se que haja inquérito policial instaurado a pedido do ofendido ou de seu representante legal para sua utilização em futura ação penal privada. Caso ocorra a renúncia expressa ou, então, pratique o ofendido ato incompatível com a vontade de ajuizar a ação penal privada, como, por exemplo, organizar a festa do aniversário do autor da infração, é possível ser requerido à autoridade judiciária o trancamento do inquérito policial, visto que, se não haverá ação penal, o respectivo inquérito policial não pode tramitar para apuração do fato delituoso. Daí se vê, mais uma vez, a correlação entre a justa causa para a ação penal e para o inquérito policial.

O perdão também é outro instituto da ação penal privada, mas assim como a perempção, não interessa ao presente estudo, visto que é causa de extinção da punibilidade após a propositura da ação (Código Penal, artigos 105 e 106 e Código de Processo Penal, artigos 55 e ss.). Como estamos estudando o trancamento do inquérito policial, que é anterior à propositura da ação penal privada, não há relação entre seus termos e o inquérito.

1.20.9

Retratação do agente

Há alguns crimes que admitem a retratação do agente, acarretando a extinção da punibilidade (Código Penal, art. 107, VI).

A retratação nada mais é do que a conduta do ofensor de retirar o que disse, confessar o erro que cometeu, desdizer-se. ${ }^{249}$

$\mathrm{O}$ art. 143 do Código Penal, que trata dos crimes de calúnia e difamação, admite que o querelado, antes da sentença, retrate-se cabalmente.

A primeira observação que se faz necessária é a de que a retratação só tem cabimento nos crimes de calúnia e de difamação, não sendo possível sua utilização no crime de injúria, que é o outro crime contra a honra tratado pelo Código Penal.

$249 \quad$ Ibidem, p. 751. 
Por outro lado, quando se fala em querelado e antes da sentença, entendemos que a melhor interpretação é a de que não é somente na fase judicial da ação penal privada que é possível a retratação, daí por que não é somente possível ao querelado, mas também ao investigado, na fase do inquérito policial se retratar, afinal de contas, não existe razão lógica para que se aguarde o término do inquérito policial instaurado a pedido de quem tem qualidade para intentar a ação penal privada para, somente após a realização de todas as diligências, como oitiva do ofendido, do investigado, elaboração de relatório final e encaminhamento a juízo ou entrega por traslado ao ofendido, com apresentação da queixa e citação do querelado, ser dada a oportunidade a este de se retratar.

Assim, é possível que já na fase do inquérito policial o investigado se retrate, seja por meio de sua oitiva ou mesmo por meio de declaração escrita assinada de próprio punho.

Nesse caso, a autoridade policial, que não tem competência para decretação de extinção da punibilidade, deverá remeter os autos a juízo, para que a autoridade judiciária, após a oitiva do Ministério Público, prolate a sentença de extinção da punibilidade com fundamento no artigo 107, VI do Código Penal.

Não há necessidade de oitiva do ofendido, somente do Ministério Público para a autoridade judiciária julgar extinta a punibilidade, uma vez que a retratação do agente não depende de aceitação do ofendido.

Na hipótese de a autoridade policial não remeter o inquérito a juízo e continuar realizando as investigações, poderá o investigado requerer à autoridade judiciária o trancamento do inquérito policial com fundamento na sua retratação.

A outra hipótese de retratação prevista no Código Penal, que é a do crime de falso testemunho ou falsa perícia, somente permite falar em trancamento do inquérito policial se o autor da falsidade tiver se retratado antes da sentença no processo em que ocorreu o ilícito (Código Penal, art. 342, $\S 2^{\circ}$ ) e, ainda assim, vier a ser instaurado inquérito policial para apuração desse crime. 
É evidente. Se o autor do fato se retratou antes da sentença no processo onde cometeu o crime, não há fundamento para a abertura do inquérito policial, visto que o Código Penal previu a possibilidade de retratação, que acarreta a extinção da punibilidade. Se ainda assim for instaurado inquérito policial, o autor do fato poderá requerer à autoridade judiciária competente seu trancamento, eis que indevidamente instaurado, encerrando-se as investigações.

Importante consignar que havia outras duas hipóteses de extinção da punibilidade no Código Penal e que poderiam acarretar eventual pedido de trancamento do inquérito policial: o casamento da ofendida com o ofensor nos denominados crimes contra os costumes ou o casamento da ofendida com terceiro, também nos crimes contra os costumes, quando não praticados com violência real ou grave ameaça e desde que a ofendida não solicitasse o prosseguimento do inquérito ou da ação penal no prazo de 60 dias, contados da celebração do casamento.

Essas hipóteses não mais constam do art. 107 do Código Penal, haja vista que foram revogados os incisos VII e VIII que delas tratavam pela Lei n. 11.106, de 28-3-2005.

Por fim, é de se consignar que a última hipótese de extinção da punibilidade prevista no art. 107 do Código Penal não interessa a este estudo, já que trata do perdão judicial, que é instituto reservado à fase judicial e permite que o juiz deixe de aplicar a pena em casos em que a infração atinja o próprio réu de forma tão grave que torna desnecessária a aplicação de sanção.

Assim, não se fala em trancamento de inquérito policial por meio de perdão judicial, que é matéria estranha a ele.

Contudo, há quem defenda ser possível o arquivamento do inquérito policial em caso de previsão de perdão judicial, sob o fundamento de não serem seus elementos de difícil constatação, o que aliviaria o Poder Judiciário de um procedimento desnecessário, sustando a marcha da investigação. 250

250 TEOTÔNIO, Paulo José Freire; MARTINS, Carlos Renato Sampaio. O perdão judicial e o arquivamento do inquérito policial. Revista Síntese de Direito Penal e Processo Penal. Porto Alegre: Síntese, ano IV, nº 25, p. 34-40, abr./maio 2004. 
Segundo esse entendimento, o caminho seria muito mais curto para a concessão do perdão judicial. Ao analisar as provas constantes do inquérito policial e a presença dos elementos necessários, o Ministério Público solicitaria a concessão do benefício ao magistrado no próprio pedido de seu arquivamento. ${ }^{251}$

Entendemos que, nessa hipótese, sendo o perdão judicial causa de extinção da punibilidade, o arquivamento faria coisa julgada formal e material, não sendo possível o posterior desarquivamento do inquérito policial, ainda que surjam novas provas (Código de Processo Penal, art. 18 e Súmula 524 do Supremo Tribunal Federal).

Caso, ainda assim, seja desarquivado o inquérito policial, poderá o investigado requerer seu trancamento, pondo fim ao prosseguimento das investigações.

1.20.10

\section{Cumprimento da pena no estrangeiro e ressarcimento do dano no peculato culposo}

$\mathrm{O}$ art. $7^{\circ}, \S 2^{\circ}, d$ do Código Penal trata do cumprimento de pena no estrangeiro, por crime lá praticado, quando for possível a aplicação da lei penal brasileira, como forma de extinção da punibilidade. ${ }^{252}$

De fato. Caso o agente tenha cumprido a pena fora do Brasil por aplicação da lei brasileira, não pode ser instaurado inquérito policial para posterior propositura da ação penal, com aplicação de pena, uma vez que isso acarretaria verdadeiro bis in idem, ou seja, o agente cumpriria duas penas pelo mesmo crime.

Caso, ainda assim, seja instaurado inquérito policial para a investigação do fato praticado pelo investigado fora do país - o que é muito difícil de ocorrer, já que a autoridade policial provavelmente não tomará conhecimento da ocorrência do crime no estrangeiro - poderá ele requerer à autoridade judiciária competente o trancamento do inquérito policial com fundamento na extinção da punibilidade pelo cumprimento da pena.

\footnotetext{
Ibidem, p. 35 .

252 FRAGOSO, Heleno Cláudio. Lições de direito penal. 15 ed. rev. atual. Rio de Janeiro: Forense, 1994, p. 400.
} 
No crime de peculato culposo, se antes da prolação da sentença irrecorrível houver a reparação do dano, extingue-se a punibilidade (Código Penal, art. 312, § $3^{\circ}$ ).

Pela mesma razão que sustentamos para a hipótese de retratação do agente antes $d a$ sentença, entendemos ser possível a reparação do dano já na fase do inquérito policial, não sendo necessário aguardar a ação penal, com todas as suas consequências, para somente lá ocorrer a reparação de dano, ou mesmo antes do inquérito.

Se ainda assim ocorrer o prosseguimento ou a instauração de inquérito policial, seu trancamento poderá ser solicitado pelo imputado.

\subsection{Trancamento em decorrência de obtenção das provas por meios ilícitos}

O direito dos interessados em introduzir, seja no processo, seja no inquérito policial, as provas úteis e necessárias à demonstração dos fatos não é absoluto. Em verdade, este direito sofre limitações em razão da tutela conferida pelo ordenamento a outros valores e interesses também merecedores de proteção. ${ }^{253}$

Segundo a Constituição Federal, "são inadmissíveis, no processo, as provas obtidas por meios ilícitos (art. 5, LVI).

Quando se fala em provas ilícitas, quer-se dizer de provas obtidas por meios que atentem contra a Constituição ou normas infraconstitucionais.

Para Guilherme de Souza Nucci, tanto será prova ilícita aquela obtida com violação de uma norma penal - como a confissão extraída mediante tortura - como a que viole norma processual penal - como o laudo assinado por um perito que não seja oficial. ${ }^{254}$

Há, porém, quem entenda que se classifica a prova como ilícita quando obtida com violação das regras de direito material, ao passo que se classifica como prova ilegítima

\footnotetext{
253 GOMES FILHO, Antonio Magalhães. Direito à prova no processo penal. São Paulo: Revista dos Tribunais, 1997, p. 91.

254 NUCCI, Guilherme de Souza. Provas no processo penal. São Paulo: Revista dos Tribunais, 2009, p. 31.
} 
aquela obtida com violação das regras de direito processual. Ambas fazem parte do gênero de provas vedadas. ${ }^{255}$ Fala-se, também, em prova vedada quando obtida de forma contrária a um princípio do direito positivo. ${ }^{256}$

Essa classificação é importante, na medida em que se houver prova ilegítima, haverá nulidade do ato, uma vez que ausentes os requisitos necessários à configuração de sua validade ${ }^{257}$, devendo o ato ser renovado ${ }^{258}$ com a observância das formalidades legais (Código de Processo Penal, art. 573), ao passo que a prova ilícita é inadmissível no processo e no inquérito e deles deverá ser desentranhada.

Gomes Filho cita a pena da inutilizzabilità do direito processual penal italiano para reforçar essa diferenciação entre provas ilícitas e provas ilegítimas, sustentando que a regra do art. 191 do Código de Processo Penal italiano de 1988 se aplica às proibições previstas não só na lei processual penal, mas também àquelas previstas na lei penal. ${ }^{259}$ Essa norma dispõe que as provas obtidas com violação dos deveres estabelecidos pela lei não podem ser utilizadas (art. 191.1). Além disso, a inutilizabilidade pode ser reconhecida também de ofício em cada estado e grau do procedimento (art. 191.2).

O Código de Processo Penal, por sua vez, dispõe que "são inadmissíveis, devendo ser desentranhadas do processo, as provas ilícitas, assim entendidas as obtidas em violação a normas constitucionais e legais" (art. 157, caput).

Destarte, caso uma prova seja considerada ilícita, deverá ser desentranhada dos autos. Além disso, deverá ser inutilizada (art. 157, § $3^{\circ}$, do Código de Processo Penal).

\footnotetext{
255 Da prova penal: tipo processual, provas típicas e atípicas. Campinas: Conceito Millennium, 2008, p. 121.

256 GRINOVER, Ada Pellegrini; GOMES FILHO, Antonio Magalhães; FERNANDES, Antonio Scarance. As nulidades no processo penal. 12a ed. rev. atual. São Paulo: Revista dos Tribunais, 2011, p. 126.

257 ZILLI, Marcos Alexandre Coelho. A iniciativa instrutória do juiz no processo penal. São Paulo: Revista dos Tribunais, 2003, p. 157.

258 GRINOVER, Ada Pellegrini; GOMES FILHO, Antonio Magalhães; FERNANDES, Antonio Scarance. As nulidades no processo penal. 12 ${ }^{\mathrm{a}}$ ed. rev. atual. São Paulo: Revista dos Tribunais, 2011, p. 127.

259 GOMES FILHO, Antonio Magalhães. Direito à prova no processo penal. São Paulo: Revista dos Tribunais, 1997, p. 103.
} 
Mas e no caso de inquérito policial? Deverá ser desentranhada a prova ilícita e inutilizada? Qual será o proveito de seguir tramitando o inquérito se a prova essencial tiver sido obtida por meio ilícito?

Em primeiro lugar, quando a Constituição Federal fala em inadmissibilidade de provas obtidas por meios ilícitos no processo, evidentemente que a melhor interpretação é pela inadmissibilidade da prova ilícita também no inquérito policial.

Além disso, já estudamos a correlação entre a justa causa para o inquérito policial e para a ação penal, demonstrando a íntima relação entre o conjunto de atos investigativos e o processo. Se a prova essencial tiver sido obtida por meio ilícito no inquérito, nenhuma utilidade haverá em seguir sua tramitação, visto que não poderá ser utilizada no processo justamente em razão dessa correlação entre inquérito e a ação penal.

Assim, caso obtida prova no inquérito por meio ilícito, deverá ser desentranhada e inutilizada, devendo os autos ser encaminhados a juízo para que seja determinado seu encerramento. Caso isso não ocorra, poderá o imputado pedir seu trancamento ao órgão jurisdicional competente.

A reforma do Código de Processo Penal pela Lei n. 11.690, de 9-6-2008, incorporou ao art. 157 do Código de Processo Penal três parágrafos. Sobre um deles já discorremos ( $\S 3^{\circ}$ que trata da inutilização da prova). Os demais tratam da prova ilícita por derivação $\left(\S 1^{\circ}\right)$ e da fonte independente $\left(\S 2^{\circ}\right)$.

A prova ilícita por derivação é aquela que decorre da prova originalmente obtida por meio ilícito. Não haveria razão para se retirar uma prova ilícita e depois ser utilizada a prova derivada daquela. Se há uma escuta telefônica sem autorização judicial, e por meio dela é localizada uma testemunha, ante a ilicitude da primeira, não poderá ser aproveitada a prova testemunhal por ser derivada de prova obtida por meio ilícito. ${ }^{260}$

Na hipótese acima, se essa prova testemunhal for essencial, não havendo outra para supri-la, ocorrerá hipótese de trancamento.

260 NUCCI, Guilherme de Souza. Provas no processo penal. São Paulo: Revista dos Tribunais, 2009, p. 32-33. 
Sendo assim, devem ser diferenciadas as situações ocorridas no inquérito. Caso a prova obtida de forma ilícita seja fundamental para o oferecimento da denúncia e não houver outras provas que a supram, o inquérito deverá ser encerrado ou, se não o for, trancado por decisão judicial ante a falta de justa causa para seu prosseguimento. ${ }^{261}$ Porém, se houver outras provas produzidas no inquérito policial e que sejam suficientes para a apresentação da acusação, não se fala em trancamento ou em encerramento das investigações.

Se a prova ilícita servir para absolver o acusado, recorre-se ao princípio da proporcionalidade para valer a preponderância do princípio constitucional da presunção de inocência e o da ampla defesa, visto que vinculados à liberdade individual. ${ }^{262}$

Dessa forma, ainda que a prova ilícita tenha sido obtida pelo próprio réu, é possível que seja admissível em seu favor mediante a aplicação do princípio da proporcionalidade dada a justificação legal da antijuridicidade, como a legítima defesa. ${ }^{263}$ Em outras palavras, o princípio da proporcionalidade fundamenta a admissão da prova ilícita no inquérito e no processo desde que em prol do imputado ou acusado. ${ }^{264}$ Essa aplicação do princípio da proporcionalidade com vistas à admissão da prova ilícita em favor do réu também deve ser considerada na ótica do direito de defesa, que também é assegurado constitucionalmente. ${ }^{265}$ O direito da prova à inocência também decorre da dignidade da pessoa humana como valor insuperável na ótica da sociedade democrática. ${ }^{266}$ Assim, admite-se, com base no princípio da proporcionalidade, a prova ilícita como forma de demonstrar a inocência de um réu. ${ }^{267}$

\footnotetext{
$261 \quad$ FERNANDES, Antonio Scarance. Processo penal constitucional. $6^{\text {a }}$ ed. rev. amp. atual. São Paulo: Revista dos Tribunais, 2010, p. 89.

NUCCI, Guilherme de Souza. Provas no processo penal. São Paulo: Revista dos Tribunais, 2009, p. 33.

AVOLIO, Luiz Francisco Torquato. Provas ilícitas: interceptações telefônicas, ambientais e gravações clandestinas. $3^{\mathrm{a}}$ ed. rev. amp. atual. São Paulo: Revista dos Tribunais, 2003, p. 67. GRINOVER, Ada Pellegrini; GOMES FILHO, Antonio Magalhães; FERNANDES, Antonio Scarance. As nulidades no processo penal. $12^{\mathrm{a}}$ ed. rev. atual. São Paulo: Revista dos Tribunais, 2011, p. 129.

GOMES FILHO, Antonio Magalhães. Direito à prova no processo penal. São Paulo: Revista dos Tribunais, 1997, p. 106.

ZILLI, Marcos Alexandre Coelho. A iniciativa instrutória do juiz no processo penal. São Paulo: Revista dos Tribunais, 2003, p. 158.
} 
Ademais, deve-se admitir a existência de exceções à regra constitucional quando outro valor fundamental também reconhecido na Constituição Federal mereça proteção, de modo que, pelo critério da proporcionalidade, o direito fundamental seja mais relevante do que o bem atingido com a obtenção da prova. ${ }^{268}$ Como o direito à absolvição decorre da presunção de inocência e do direito a ampla defesa, direitos fundamentais, evidente sua prevalência sobre a proibição de produção de provas ilícitas, com base na proporcionalidade, até para que o verdadeiro autor do fato não permaneça impune, sendo evidente que o Estado não tem interesse em punir um inocente.

Sobre o tema das provas ilícitas, As Mesas de Processo Penal, atividade ligada ao Departamento de Direito Processual da Faculdade de Direito da Universidade de São Paulo, se posicionaram por meio das seguintes Súmulas:

"Súmula 48 - Denominam-se ilícitas as provas colhidas com infringência a normas e princípios de direito material.

"Súmula 49 - São processualmente inadmissíveis as provas ilícitas que infringem normas e princípios constitucionais, ainda quando forem relevantes e pertinentes, e mesmo sem cominação processual expressa.

"Súmula 50 - Podem ser utilizadas no processo penal as provas ilicitamente colhidas, que beneficiem a defesa". ${ }^{269}$

Como estamos tratando de inquérito policial, essas questões devem ser levadas em consideração para fins de trancamento.

Por outro lado, quando não ficar evidenciado o nexo de causalidade entre a prova obtida por meio ilícito e a prova derivada, ou quando as provas derivadas puderem ser obtidas por uma fonte independente da primeira, serão admitidas no inquérito ou no processo (Código de Processo Penal, art. 157, $\S 1^{\circ}$ ) e, nesse caso, não se fala em trancamento.

\footnotetext{
268 FERNANDES, Antonio Scarance. Processo penal constitucional. $6^{\text {a }}$ ed. rev. amp. atual. São Paulo: Revista dos Tribunais, 2010, p. 84-85.

269 GRINOVER, Ada Pellegrini; GOMES FILHO, Antonio Magalhães; FERNANDES, Antonio Scarance. As nulidades no processo penal. $12^{\mathrm{a}}$ ed. rev. atual. São Paulo: Revista dos Tribunais, 2011, p. 131.
} 
A fonte independente é aquela que por si só seria capaz de conduzir ao fato objeto da prova, desde que seguidos os trâmites próprios da investigação criminal (Código de Processo Penal, art. 157, $\S 2^{\circ}$ ). Pode-se citar como exemplo a realização de busca e apreensão por duas equipes diversas de policiais civis em uma residência. A primeira equipe realiza a busca sem autorização judicial, prova ilícita, portanto. A segunda equipe realiza a busca munida de mandado judicial quase que simultaneamente. Prova lícita, sem dúvida. Essa prova lícita é independente da primeira, de modo que pode ser juntada no inquérito policial sem qualquer mácula. Nesse caso, não se fala em trancamento por não ter sido a prova obtida por meio ilícito, apesar daquela realizada sem a observância do trâmites legais.

As provas ilícitas, uma vez inadmissíveis, não são prova. É um não ato. Não existem juridicamente e não têm nenhuma eficácia. ${ }^{270}$ Daí porque, uma vez obtidas as provas por meios ilícitos no inquérito policial, sendo elas de natureza essencial e o único meio de prova que possa embasar futura ação penal, deverá ele ser encaminhado a juízo para ser encerrado, sob pena de ser trancado caso assim não se proceda.

\subsection{Trancamento por aplicação do princípio da insignificância ou da bagatela}

O que é princípio da insignificância? Relaciona-se à ilicitude (antijuridicidade) ou à tipicidade penal?

De um modo geral, a ilicitude corresponde à contrariedade de um fato em relação ao Direito. ${ }^{271}$ É uma relação ou propriedade que se atribui ao fato típico, ou seja, é o antagonismo ou oposição ao direito ${ }^{272}$.

\footnotetext{
Ibidem, p. 138.

VICO MAÑAS, Carlos. Princípio da insignificância: excludente da tipicidade ou da ilicitude? In: SUANNES, Adauto; TORON, Alberto Zacharias; BIANCHINI, Alice et al. (colab.). Escritos em homenagem a Alberto Silva Franco. São Paulo: Revista dos Tribunais, p. 143-150, 2003.

272 TOLEDO, Francisco de Assis. Princípios básicos de direito penal. $3^{\mathrm{a}}$ ed. São Paulo: Saraiva, 1987, p. 149.
} 
Portanto, um fato será ilícito quando, seja na forma de ação, seja na forma de omissão, se opuser à ordem jurídica, estabelecendo com esta uma relação de contraposição, ou seja, é a propriedade que determinados comportamentos têm de se oporem à ordem jurídica. ${ }^{273}$

E a tipicidade? Ela tem relação com o tipo penal, ou seja, com a descrição dos dados materiais que caracterizam de forma objetiva o crime.

Assim, a tipicidade é a adequação do fato humano ao tipo penal.

Contudo, para que determinado fato seja típico, não basta a mera adequação formal a ele, mas também a conduta deve ser materialmente lesiva aos bens jurídicos tutelados. Destarte, para que se fale em tipicidade, a conduta deve ter significância não só no aspecto formal, mas também no aspecto material, como algo com conteúdo valorativo.

Destarte, a tipicidade não é a simples subsunção de um fato ao tipo penal abstratamente descrito. ${ }^{274}$

Só se fala em tipicidade quando o bem jurídico protegido pela norma penal seja atingido a ponto de a conduta ter relevância para o direito penal, haja vista que este não deve se ocupar de bagatelas, mas somente a ponto de atingir o necessário para a proteção reclamada pela norma, uma vez que devem ser consideradas materialmente atípicos os fatos lesivos insignificantes para a vida em sociedade. ${ }^{275}$

Isso significa que determinada conduta pode formalmente se adequar ao tipo penal, mas por ser materialmente insignificante, exclui-se a tipicidade dessa conduta, evitando-se que o direito penal seja utilizado para alcançar fatos irrelevantes para a vida em sociedade.

\footnotetext{
Ibidem, p. 149.

274 VICO MAÑAS, Carlos. O princípio da insignificância como excludente da tipicidade no direito penal. São Paulo: Saraiva, 1994, p. 55.

VICO MAÑAS, Carlos. Princípio da insignificância: excludente da tipicidade ou da ilicitude? In: SUANNES, Adauto; TORON, Alberto Zacharias; BIANCHINI, Alice et al. (colab.). Escritos em homenagem a Alberto Silva Franco. São Paulo: Revista dos Tribunais, p. 143-150, 2003.
} 
Daí porque o princípio da insignificância se relaciona com a tipicidade penal para excluir do campo de aplicação do direito penal fatos irrelevantes, insignificantes para o convívio em sociedade.

Serve, assim, o princípio da insignificância para restringir o campo de atuação do tipo penal. Exclui-se a tipicidade do fato, de modo que não há crime a ser apurado. ${ }^{276}$

Sua natureza jurídica é a de causa supralegal de exclusão da tipicidade.

O princípio foi concebido por Claus Roxin, que propôs a introdução, no sistema penal, de princípio geral para a determinação do injusto, atuando como regra auxiliar de interpretação. $^{277}$

Segundo esse princípio, o fato penalmente insignificante deve ser excluído da tipicidade penal, recebendo tratamento adequando, se o caso, como ilícito civil ou administrativo, de acordo com o tratamento legal extrapenal. ${ }^{278}$

É o que ocorre, por exemplo, com os crimes contra a ordem tributária. Não se pode falar em tipicidade, no seu aspecto material, quando for reduzido o valor do tributo sonegado. $^{279}$

Segundo Claus Roxin, a interpretação dos tipos penais deve ser restritiva a ponto de somente ser conceituado no âmbito da punibilidade aquilo que seja indispensável para a proteção do bem jurídico. Em sua palavras, o princípio da insignificância "permite en la mayoría de los tipos excluir desde un principio daños de poca importancia: maltrato no es cualquier tipo de daño de la integridad corporal, sino solamente uno relevante; análogamente deshonesto en el sentido del Código penal es sólo la acción sexual de una cierta importancia, injuriosa en una forma delictiva es sólo la lesión grave a la pretensión social de respeto. Como 'fuerza' debe considerarse únicamente un obstáculo de cierta

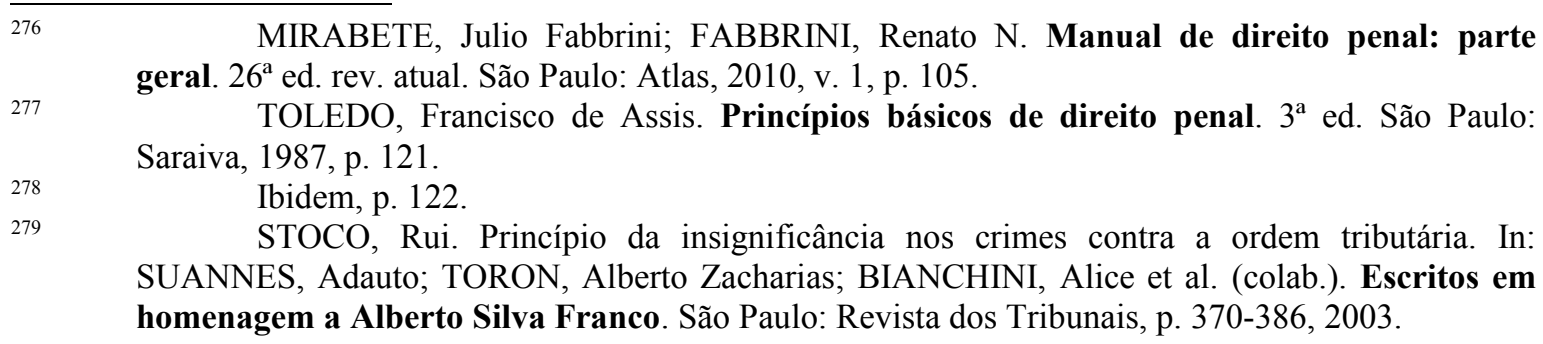


importancia, igualmente también la amenaza debe ser 'sensible' para pasar el umbral de la criminalidad. Si con estos planteamientos se organizara de nuevo consecuentemente la instrumentación de nuestra interpretación del tipo, se lograría, además de una mejor interpretación, una importante aportación para reducir la criminalidad en nuestro país". 280

Portanto, pela interpretação restritiva, somente a conduta relevante no sentido material teria "força" para adequá-la ao tipo penal, de modo que as condutas de pouca monta, insignificantes, tais como o dano quase imperceptível à integridade corporal ou a pequeníssima gravidade da injúria não teriam relevância para o direito penal, excluindo a tipicidade e tornando tais condutas ínfimas fatos atípicos.

Não se confunde o princípio da insignificância com o princípio da intervenção mínima. Este último se dirige ao legislador e visa reduzir o número de normas incriminadoras, ao passo que o princípio da insignificância é voltado para o juiz do caso concreto que deve verificar se o dano ocorrido ao bem jurídico tutelado pela norma penal incriminadora é materialmente significante ou irrisório.

Da mesma forma, não se confunde o princípio da insignificância com o perdão judicial. No primeiro, exclui-se a própria tipicidade penal e o agente deve ser absolvido se a persecução penal já atingiu a fase judicial, ao passo que no perdão judicial há processo e condenação, mas a pena deixa de ser aplicada pelo juiz se preenchidos determinados requisitos, embora essa pena não se considere para fins de reincidência (Código Penal, art. 120). É a hipótese da apropriação indébita previdenciária (Código Penal, art. 168A, § $\left.3^{\circ}\right){ }^{281}$

Uma vez estabelecidos os fundamentos do princípio da insignificância é de ser feita a seguinte pergunta: É possível o trancamento do inquérito por aplicação do princípio da insignificância?

Entendemos que sim.

\footnotetext{
280 ROXIN, Claus. Política criminal y sistema del derecho penal. Trad. Francisco Muñoz Conde. Barcelona: Bosch, 1972, p. 52-53.

281 STOCO, Rui. Princípio da insignificância nos crimes contra a ordem tributária. In: SUANNES, Adauto; TORON, Alberto Zacharias; BIANCHINI, Alice et al. (colab.). Escritos em homenagem a Alberto Silva Franco. São Paulo: Revista dos Tribunais, p. 370-386, 2003.
} 
Ora, se determinada conduta se adequar formalmente ao tipo penal, mas for materialmente insignificante, não encontramos razão para que o inquérito policial tenha curso se, ao final, após ser alcançada e exaurida a fase judicial, com todos os percalços e gastos, for reconhecida a insignificância da conduta, de modo a ser excluída a tipicidade, com a consequente absolvição do agente.

Essa questão do trancamento do inquérito policial em razão do princípio da insignificância foi tratada em sentença proferida em habeas corpus (n. 2009.61.81.0124596 - j. 10.12.2009 - $3^{\text {a }}$ Vara Criminal Federal de São Paulo) que aborda a questão da existência ou não de coação ilegal por parte da autoridade policial que instaurou inquérito policial a partir de representação fiscal para fins penais elaborada pela Receita Federal decorrente do não recolhimento de tributos incidentes sobre a importação de produtos eletroeletrônicos. ${ }^{282}$

O Tribunal Regional Federal da $3^{\mathrm{a}}$ Região, em Aresto relatado pela Desembargadora Ramza Tartuce, reconheceu a possibilidade de trancamento do inquérito policial em razão do reconhecimento do princípio da insignificância, nos seguintes termos:

“1. O juiz tem o dever de impedir potencial coação ilegal. O exercício deste dever é pautado pela prova da sua possível ocorrência. 2. A concessão de habeas corpus, de ofício, é providência adequada para trancar inquérito policial instaurado para investigar fato penalmente insignificante. 3. É penalmente insignificante a emissão de cheque, sem a suficiente provisão de fundos em poder do banco sacado, de valor inferior ao mínimo exigido para a execução forçada da dívida ativa da União. 4. Supremo Tribunal Federal: dívida tributária ínfima não autoriza o ajuizamento de execução fiscal (STF - RE 235.2708-SP - Rel. o Min. Nelson Jobim). 5. É corolário do princípio liberal da gradação das sanções que, vetado o menos - a execução fiscal -, não se permite o mais - a ação penal. 6 . Remessa oficial e recurso em sentido estrito improvidos". (TRF $3^{\text {a }}$ Reg. - Proc. 2004.61.81.000132-0 - RCCR 2743 - DJU 09.09.2003 - j. em 27.05.2003 - Rel. Ramza Tartuce).

282 O direito por quem o faz: aplicação do princípio da insignificância ao delito de descaminho (art. 334, CP). Trancamento do inquérito policial. Boletim do Instituto Brasileiro de Ciências Criminais. São Paulo: Instituto Brasileiro de Ciências Criminais, ano 17, nº 208, março/2010. 
Assim, é possível sustentar que o princípio da insignificância pode fundamentar o trancamento de inquérito policial, com encerramento das investigações, inclusive de ofício.

\subsection{Trancamento por não observância do princípio da duração razoável do processo}

É possível o trancamento do inquérito policial por desrespeito ao princípio constitucional da duração razoável do processo?

O que é duração razoável do processo? Quais os seus fundamentos? Esse princípio é aplicável ao inquérito policial ou somente à fase judicial?

A primeira observação importante é a de que "o processo não pode durar para sempre". ${ }^{283}$

É importante ressaltar que quando se fala em duração razoável isso não importa em julgamentos com supressão de direitos e garantias para justificar atuação estatal viciada com o fim de decidir as causas de forma apressada, sem observância das normas que regulam o processo e o procedimento.

Em verdade, o ideal é que se busque um equilíbrio entre a celeridade do processo e as garantias fundamentais do imputado, de modo que a decisão final, ou seja, a atuação estatal de julgar, seja realizada de forma legítima. Quanto mais rápido for o processo com a supressão de direitos ou quanto mais demorar sua tramitação, ainda que todos os direitos sejam garantidos, maior será a sensação de atuação viciada do Estado-juiz, o que reflete desprestígio dessa atividade estatal perante a sociedade.

É importante ressaltar que o tempo da duração de um processo, se for demais alongado, causa prejuízos ao imputado ainda que não haja prisão cautelar, haja vista que mesmo livre do cárcere, não se vê ele livre do estigma e da angústia ${ }^{284}$.

\footnotetext{
283 CARNELUTTI, Francesco. As misérias do processo penal. $2^{\mathrm{a}}$ ed. Leme: Edijur, 2010, p. 70. 284 LOPES JUNIOR, Aury. Direito ao processo penal no prazo razoável. Revista Brasileira de Ciências Criminais. São Paulo: Revista dos Tribunais, v. 65, p. 209-250, mar./abr. 2007.
} 
$\mathrm{O}$ acesso à ordem jurídica justa (Constituição Federal, art. $5^{\circ}, \mathrm{XXXV)}$ pressupõe o direito à obtenção de uma decisão em prazo razoável, sem dilações indevidas. Para que a tutela jurisdicional seja adequada, mister que a decisão ocorra em lapso de tempo razoável, de forma proporcional à complexidade do processo. ${ }^{285}$

De toda forma, o fator tempo é um ponto delicado do direito processual penal, uma vez que envolve a liberdade do indivíduo. ${ }^{286} \mathrm{E}$ o andamento do inquérito policial possui fundamental relevância nesse tema, eis que, normalmente, esse conjunto de atos precede a ação penal, onde se discutirá sobre a culpabilidade do imputado.

Ademais, o retardamento da atividade persecutória estatal traz sensação de impunidade à sociedade e, ao mesmo tempo, sentimento de injustiça e desproporção ao imputado, independentemente se, ao final, ele vier a ser considerado culpado ou inocente. Daí porque a demora da tutela jurisdicional atenta contra a efetividade do processo.

Nos tempos modernos, onde as relações se desenvolvem de forma quase que automática, reclama-se do Direito a mesma agilidade. A dificuldade reside, contudo, na elaboração da legislação processual que requer uma série de formalidades, de modo que sua revisão com o intuito de criar mecanismos que acarretem a celeridade processual não ocorre com a mesma velocidade exigida para regular as relações cotidianas entre os indivíduos.

Desse modo, o Direito necessitava de um instrumento que regulasse a forma de andamento dos processos a ponto de torná-los mais céleres, sem supressão de direitos e garantias fundamentais, evidentemente. E o princípio da duração razoável do processo foi a fórmula encontrada para regular esse campo sensível do Direito que é o processual, de modo a torná-lo mais ágil com vistas a pacificar os conflitos decorrentes das relações humanas.

O direito a um julgamento em prazo razoável a todos interessa: ao ofendido, visto que a resposta estatal pronta lhe traz sensação de confiança no aparelhamento estatal; ao

\footnotetext{
285 PARIZ, Ângelo Aurélio Gonçalves. O princípio do devido processo legal: direito fundamental do cidadão. Coimbra: Almedina, 2009, p. 260.

286 BEDÊ JUNIOR, Américo; SENNA, Gustavo. Princípios do processo penal: entre o garantismo e a efetividade da sanção. São Paulo: Revista dos Tribunais, 2009, p. 253.
} 
Estado, que transmite ao jurisdicionado a eficiência do sistema que lhe cabe; por fim, à coletividade, visto que a presteza da atividade jurisdicional traz a almejada paz social, afastando a ideia de impunidade e de descrédito na justiça. ${ }^{287}$

O princípio da duração razoável do processo também se relaciona com outros princípios constitucionais.

É certo que a não observância do princípio da duração razoável acaba por fulminar o princípio da presunção da inocência, na medida em que o prolongamento injustificado do processo penal sepulta a credibilidade da versão do acusado. Do mesmo modo, o próprio direito de defesa e o contraditório são afetados pela excessiva duração do processo, visto que traz dificuldades para o eficaz exercício da resistência processual. ${ }^{288}$

E é evidente que a excessiva duração do inquérito policial tem estreita relação com as consequências nefastas causadas ao imputado quando inaugurada a fase judicial. Destarte, o princípio da duração razoável aplica-se também na fase administrativa do inquérito policial, não somente na fase do processo judicial.

O tema da duração razoável não é novo como se pensa. Já ao tempo de Beccaria era defendida a ideia da presteza da pena. Nesse sentido, vale destacar suas ponderações. Segundo ele "quanto mais a pena for rápida e próxima do delito, tanto mais justa e útil ela será. Digo mais justa, porque poupará ao réu os tormentos cruéis e inúteis da incerteza, que crescem com o vigor da imaginação e com o sentimento da própria fraqueza; mais justa, porque sendo a privação da liberdade uma pena, ela só pode preceder a sentença quando a necessidade o exigir. $\mathrm{O}$ cárcere é, pois, a simples custódia de um cidadão até que ele seja julgado culpado, e sendo essa custódia essencialmente penosa, deve durar o menor tempo possível e ser o menos dura possível. Esse tempo menor deve medir-se pela duração necessária do processo e pelo direito de anterioridade do réu ao julgamento. A duração do recolhimento ao cárcere só pode ser a necessária para impedir a fuga, ou para que não sejam ocultadas as provas dos delitos. O processo mesmo deve concluir-se no tempo mais breve possível". 289 
Vale a pena citar a conclusão de Beccaria, notadamente pelo fato de a obra ter sido originalmente publicada em 1764: "A longa demora não produz outro efeito além de dissociar cada vez mais essas duas idéias (delito e pena - grifos nossos); e ainda que o castigo de um delito cause uma impressão, será menos a de um castigo que a de um espetáculo, e isso só acontecerá após ter-se atenuado nos espectadores o horror de um certo delito em particular, que serviria para reforçar o sentimento da pena". ${ }^{290}$

De fato. Quanto menor for a duração do processo - e nessa duração se insere o inquérito policial - maior será a sensação de cumprimento da função estatal de julgar e mais legitimado será considerado seu exercício.

A questão também é analisada por estudo de Aury Lopes Junior. ${ }^{291}$

O estudo trata da demora da prestação jurisdicional no processo penal ante o princípio da sua razoável duração.

Cita o art. $5^{\circ}$, LXXVIII, da Constituição Federal, que previu o princípio da duração razoável do processo, acrescentado à Carta Magna pela Emenda Constitucional n. 45, de 812-2004, e atesta que a garantia já era prevista anteriormente nos artigos 7.5 e 8.1 da Convenção Americana dos Direitos Humanos.

Faz o questionamento sobre o que é duração razoável do processo e cita a jurisprudência do Tribunal Europeu de Direitos Humanos sobre o assunto: "Desde o caso 'Wemhoff' (STEDH de 27/06/1968), o TEDH vem debatendo-se em torno de critérios para definir o que seja um prazo razoável para julgamento. A discussão evoluiu e, atualmente, trabalha com as seguintes variáveis: a) complexidade do caso; b) a atividade processual do interessado (que obviamente não poderá se beneficiar de sua própria torpeza); c) a conduta das autoridades judiciárias (como um todo, abrangendo polícia, MP e juiz). A eles, acrescente-se o princípio da proporcionalidade. Mas o resultado final, ainda assim, é excessivamente vago e discricionário. Esse é o grave inconveniente da adoção da teoria do

\footnotetext{
Ibidem, p. $80-81$.

291 LOPES JUNIOR, Aury. A (de) mora jurisdicional e o direito de ser julgado em um prazo razoável no processo penal. Boletim do Instituto Brasileiro de Ciências Criminais. São Paulo: Instituto Brasileiro de Ciências Criminais, ano 13, $\mathrm{n}^{\mathrm{o}}$ 152, p. 4-5, jul. 2005.
} 
não-prazo, assim chamada pela falta de um critério claro (prazo) de duração do processo. A ausência de um limite de duração máxima do processo penal compromete a eficácia do direito de ser julgado em um prazo razoável, na medida em que conduz ao emprego de uma cláusula genérica (razoável duração), de conteúdo vago, impreciso e indeterminado".

E prossegue: "É óbvio que o legislador deve sim estabelecer de forma clara os limites temporais do processo e das prisões cautelares, até porque, as pessoas têm o direito de saber (dimensão democrática), de antemão e com precisão, qual é o tempo máximo que poderá durar um processo penal. Estamos diante de exercício de poder e que, portanto, necessita e exige limites e controle (inclusive temporal). Trata-se de um mínimo de respeito às regras éticas do jogo (e aqui emprego o conceito de Calamandrei, il processo come giuocco, ou de guerra, de James Goldschmidt)".

Diante da falta de regras claras e específicas no direito brasileiro sobre o que seja prazo razoável, aponta o processo penal paraguaio como paradigma: "Um bom exemplo de limite normativo interno encontramos no CPP paraguaio: o prazo máximo de duração do processo penal será de 3 anos (art. 136), após o qual, o juiz o declarará extinto (adoção de uma solução processual extintiva). Também fixa um limite para a fase pré-processual, que uma vez superado, dará lugar a extinção da ação penal. Por fim, existe ainda a resolução ficta, quando a Corte Suprema não julgar um recurso interposto no prazo devido. Se o recurso é da defesa, uma vez superado o prazo máximo previsto para sua tramitação, entender-se-á que o pedido foi provido na sua integralidade. Quando o postulado for desfavorável ao imputado (recurso interposto pelo acusador), superado o prazo sem julgamento, o recurso será automaticamente rechaçado. Além disso, deve-se estabelecer um dever de revisar periodicamente o decreto de prisão cautelar, pelo próprio juiz, como o fazem o CPP português (a cada 3 meses, art. 213.1) ou o alemão (a cada 3 meses, StPO $\S$ 122). É fundamental definir claramente o prazo máximo de duração do processo penal, das prisões cautelares e, ainda, em relação a essas últimas, o dever de revisar periodicamente a medida, para evitar que o provisório transforme-se uma desmedida pena antecipada".

Destarte, no campo do inquérito policial, o Código de Processo Penal paraguaio, ao se referir à fase pré-processual citada pelo autor, também prevê prazo para sua tramitação, sob pena de extinção da ação penal, de modo que a ele também se aplica o princípio da duração razoável do processo, sob pena de extinção, o que para nós seria o trancamento. 
Diante da falta de critérios no nosso sistema processual penal para se definir o alcance do que seria prazo razoável, e para que a não observância do princípio constitucional não o torne ineficaz, propõe soluções de natureza compensatórias e sancionatórias. Assim, a demora processual poderia ser compensada por meio de indenização na esfera cível, ao passo que seria compensada com a atenuação da pena ao final aplicada - com aplicação da atenuante genérica prevista no artigo 66 do Código Penal $^{292}$ - ou mesmo mediante a concessão do perdão judicial, nos casos em que é possível, como, por exemplo, no caso dos artigos 121, § $5^{\circ}$ e $129, \S 8^{\circ}$, ambos do Código Penal. Além disso, a aplicação de sanção ao servidor responsável pela dilação indevida poderia não só reparar os constrangimentos sofridos com a demora processual, mas também prevenir essa situação em casos futuros.

Outro diploma legal que se preocupou com o tempo da duração da investigação foi o Código de Processo Penal nacional argentino, que a limitou em quatro meses (art. 207), tendo como termo inicial a formalização da imputação denominada indagatoria, que se assemelha ao nosso indiciamento, eis que ela ocorre quando for provável a existência de um crime e houver suspeita fundada de que o imputado seja seu autor. ${ }^{293}$ Esse prazo pode ser prorrogado por mais dois meses se as informações colhidas forem insuficientes. Além disso, pode haver dilação por mais dois meses, perfazendo o total de oito meses quando a gravidade e a dificuldade da investigação a justificar. ${ }^{294}$

No plano regional, o Brasil aderiu à Convenção Americana dos Direitos Humanos (Pacto de São José da Costa Rica, de 22-11-1969) pelo Dec. n. 678, de 6-11-1992. E essa convenção previu a duração razoável nos artigos 7.5 e 8.1 ao tratar, respectivamente, do direito à liberdade pessoal e das garantias judiciais. E essa duração razoável prevista na Convenção compreende também o direito de o imputado ser ouvido em prazo razoável, notadamente se ele se encontra preso $^{295}$.

\footnotetext{
292 Há precedente, nesse sentido, da $5^{\text {a }}$ Câmara Criminal do Tribunal de Justiça do Rio Grande do Sul - Ap. no 70007100902, rel. Desembargador Luiz Gonzada da Silva Moura, j. 17.12.3003.

CHOUKR, Fauzi Hassan. Garantias constitucionais na investigação criminal. $3^{\mathrm{a}}$ ed. rev. amp. atual. Rio de Janeiro: Lumen Juris, 2006, p. 36-37.

Ibidem, p. 37.

GOMES, Luiz Flávio. Comentários à convenção americana sobre direitos humanos. In: GOMES, Luiz Flávio; MAZZUOLI, Valerio de Oliveira. Coleção ciências criminais. $2^{\mathrm{a}}$ ed. rev. amp. atual. São Paulo: Revista dos Tribunais, 2009, v. 4, p. 59.
} 
Por outro lado, a Emenda Constitucional n. 45, de 8-12-2004, inseriu o $\S 3^{\circ}$ ao art. $5^{\circ}$ da Constituição Federal, com o fim de regular a natureza jurídica dos tratados e convenções internacionais sobre os direitos humanos aprovados por cada Casa do Congresso Nacional, tratando-os como equivalentes às emendas constitucionais, desde que aprovados em dois turnos, por três quintos dos votos dos respectivos membros.

A conjugação do art. $5^{\circ}, \S \S 2^{\circ}$ e $3^{\circ}$ da Constituição Federal permite concluir que a Convenção Americana dos Direitos Humanos tem natureza materialmente constitucional, embora formalmente suas normas não sejam constitucionais por não terem o quorum exigido pelo $\S 3^{\circ}$ inserido no art. $5^{\circ}$ da Constituição. De todo modo, o direito ao julgamento em prazo razoável, que já era garantia explícita, por ser decorrente do princípio do devido processo legal, passou a ser expressamente assegurado pelo inciso LXXVIII ${ }^{296}$, muito embora o Direito brasileiro tenha adotado a teoria de um não-prazo.

Aliás, a partir da promulgação da Emenda Constitucional n. 45, de 8-12-2004, o direito ao julgamento em prazo razoável passou a ser considerado direito subjetivo constitucional, verdadeiro direito fundamental. ${ }^{297}$ Esse direito deve ser conferido a todos aqueles que sejam parte em um processo penal, seja como acusador, seja como acusado.

No Direito europeu, além dos casos citados do Código de Processo Penal português, que determina a revisão periódica da prisão cautelar - a cada três meses - e do Código de Processo Penal alemão, que também determina a revisão da prisão cautelar a cada três meses, importante citar a Inglaterra, a Constituição italiana, seu Código de Processo Penal e a Convenção Europeia dos Direitos do Homem.

Na Inglaterra, é possível extrair da cláusula 29 da Magna Carta o princípio de julgamento em prazo razoável. Além disso, o Ato sobre Direitos Humanos de 1998 incorporou a Convenção Europeia de Direitos do Homem. ${ }^{298}$ A Convenção Europeia dos Direitos do Homem, por sua vez, previu no art. 6 (1) a necessidade de julgamento dentro

\footnotetext{
296 BADARÓ, Gustavo Henrique; LOPES JUNIOR, Aury. Direito ao processo penal no prazo razoável. $2^{\mathrm{a}}$ ed. rev. atual. Rio de Janeiro: Lumen Juris, 2009, p. 33 ss.

297 TUCCI, Rogério Lauria. Direitos e garantias individuais no processo penal brasileiro. $3^{\mathrm{a}}$ ed. rev. amp. atual. São Paulo: Revista dos Tribunais, 2009, p. 211-212.

SPENCER, J. R. O sistema inglês. In: DELMAS-MARTY, Mireille (org.). Processos penais da Europa. Trad. Fauzi Hassan Choukr, com a colaboração de Ana Claudia Ferigato Choukr. Rio de Janeiro: Lumen Juris, p. 245-339, 2005.
} 
de um prazo razoável. Assim, no Direito inglês, o princípio da duração razoável do processo é um dos primados do Direito Processual.

A Constituição italiana prevê no art. 111 a duração razoável do processo. Segundo seus termos, cada processo se desenvolve em contraditório entre as partes, em condições de igualdade, perante um juiz imparcial e a lei deverá regular sua razoável duração.

O Código de Processo Penal italiano, de outro lado, previu a pena da "inutilizzabilità" dos elementos colhidos durante as investigações quando o Ministério Público não tenha exercitado a ação penal ou tenha pedido o arquivamento no prazo estabelecido pela lei ou prorrogado pelo juiz, sendo o prazo geral para o fim das “indagações preliminares" de dezoito meses ou de dois anos em casos especiais que especifica (Código de Processo Penal italiano, art. 407.1, 2 e 3).

Essa sanção decorrente da não observância dos prazos máximos para o término da investigação evidentemente acarreta o que para nós seria o trancamento do inquérito policial e, em decorrência, a extinção da ação penal proposta sem observância de referidos prazos e para nós serve de referência com vistas a tornar efetivo o princípio inserido em nossa Constituição em seu art. $5^{\circ}$, LXXVIII.

Por fim, já foi dito acima que a Convenção Europeia dos Direitos do Homem, em seu art. 6 (1), previu o julgamento em um prazo razoável. Segundo este dispositivo, toda pessoa tem o direito de ser ouvida de forma equitativa, publicamente e dentro de um prazo razoável por um tribunal independente e imparcial, estabelecido por lei, que decidirá sobre seus direitos e obrigações de caráter civil ou sobre o fundamento de qualquer acusação que em matéria penal se dirija contra ela.

Caso não haja observância desse dispositivo nos países que fazem parte da União Europeia, ao menos é possível assegurar esse direito por meio de petição individual ao Tribunal Europeu dos Direitos do Homem, sendo esse um dos problemas mais enfrentados pelo TEDH. ${ }^{299}$

299 CHIAVARIO, Mario. Os direitos do acusado e da vítima. In: DELMAS-MARTY, Mireille (org.). Processos penais da Europa. Trad. Fauzi Hassan Choukr, com a colaboração de Ana Claudia Ferigato Choukr. Rio de Janeiro: Lumen Juris, p. 563-619, 2005. 
De qualquer modo, não há dúvida de que o princípio da duração razoável do processo constitui elemento importante para um processo penal justo, haja vista que sua observância propicia um sistema judicial que protege o inocente da demora da prestação jurisdicional e, ao mesmo tempo, impõe a pronta punição para os culpados.

Em outro estudo muito interessante sobre o trancamento do inquérito policial decorrente da injustificada demora dos trabalhos realizados pela polícia, Ricardo Henrique Araújo Pinheiro enfrenta a questão da demora da conclusão do inquérito policial, notadamente em hipótese de crime de simples solução, na forma do art. 10, $\$ 3^{\circ}$, do Código de Processo Penal. ${ }^{300}$ Além disso, direciona o trabalho ao inquérito policial instaurado no âmbito da Polícia Federal.

Sobre o tema, aduz o seguinte: "Em regra, tratando-se de indiciado preso em virtude do flagrante ou preventivamente, o prazo para a conclusão do inquérito policial será de 15 (quinze) dias, renováveis por mais 15 (quinze) dias (artigo 66 da lei no . 5.010/66). É de se registrar que no caso de indiciado solto, a Lei que organiza a Justiça Federal de primeira instância, curiosamente, nada disse a respeito. Assim, por ocasião do artigo 10 do Código de Processo Penal o prazo para a conclusão do inquérito policial, em se tratando de réu solto e o caso for de simples solução, será de 30 (trinta) dias. Registre-se que nos termos do Código de Processo Penal, a exasperação do prazo para a conclusão do inquérito policial só deverá ocorrer nos casos de difícil solução em que haja prévia justificativa da autoridade policial ( $\$ 3^{\circ}$ do artigo 10 do CPP)".

Segundo o autor do artigo, após a publicação da Emenda Constitucional n. 45, de 812-2004, que incluiu ao art. $5^{\circ}$ da Constituição Federal o inciso LXXVIII, o Estado teria passado a controlar a eficiência do aparelho responsável pela persecução penal com vistas à celeridade ou razoável duração do processo.

Vale a pena citar trecho esclarecedor do trabalho publicado: "Nessa nova perspectiva de efetivo controle de prazo, passou-se a desenvolver o entendimento no sentido de que a injustificada exasperação do prazo para a conclusão do inquérito policial,

$300 \quad$ PINHEIRO, Ricardo Henrique Araújo. O trancamento do inquérito policial ocasionado pela injustificada demora na conclusão dos trabalhos policiais: Análise feita à luz do princípio da razoabilidade. São Paulo: Instituto Brasileiro de Ciências Criminais, dez. 2009. Disponível em: $<$ http://www.ibccrim.org.br/site/artigos>. Acesso em: 4-7-2012. 
quando o excesso não for causado pelo próprio indiciado, poderá haver a intervenção do Poder Judiciário na função precípua da investigação, determinando-se o trancamento do inquérito policial, sem prejuízo da instauração de procedimento correcional contra o causador do dano ao Estado, que neste caso é a autoridade policial”.

Sendo assim, quando o inquérito policial for instaurado para apurar crime de simples solução, se houver injustificado atraso nos trabalhos policiais, com sucessivos pedidos de dilação de prazo para sua conclusão, estaria autorizado o trancamento pela não observância do princípio da duração razoável do processo (art. $5^{\circ}$, LXXVIII), aí incluído o inquérito policial. A condição para tanto seria, como é óbvio, que o atraso não decorresse da atuação do indiciado, para que não se beneficie de sua própria torpeza.

De fato. Nada justifica a demora na conclusão dos trabalhos policiais para apuração de crimes de simples solução, com seguidos pedidos de dilação de prazo, prolongando-se sua tramitação, enquanto o indiciado aguarda para saber se irá sofrer ação penal ou não, visto que o inquérito tem por finalidade servir de base para a propositura da ação penal por seu titular.

Portanto, é decorrência do princípio da duração razoável do processo a observância de um limite razoável para que o inquérito policial seja concluído, notadamente em crimes de simples solução, sob pena de o dispositivo constitucional se tornar letra morta, até porque, o princípio é adotado na forma de um não-prazo, de forma genérica, sem previsão do prazo máximo de duração do inquérito policial.

Diante disso, não há dúvida de que é possível o trancamento do inquérito policial por ausência de justa causa em razão da injustificada demora de seu encerramento. Tal não ocorre quando essa demora é causada por conta da atuação do indiciado, já que, nesse caso, a ausência de conclusão não foi ocasionada pela autoridade policial.

Por outro lado, a favor de tal entendimento, é possível evocar o princípio constitucional da presunção de inocência (art. 5 , LVII da Constituição Federal), uma vez que a prolongada tramitação do inquérito policial sem solução, indiretamente, desde que seja injustificada e não ocorra em razão da atividade do próprio indiciado, acaba por afastar a aplicação do princípio, acarretando espécie de punição sem decisão penal 
condenatória contra o indiciado, que não vê o fim das investigações e acaba por suportar, muitas vezes injustamente, o estigma de criminoso, às vezes sem o ser.

Importante salientar que, quando se fala que a atuação do indiciado justifica a demora na tramitação do inquérito, não quer isso dizer que não possa ele atuar para tentar demonstrar, já na fase administrativa, que não ocorreu o crime ou que ele não é o seu autor, já que é possível a ele requerer diligências e propor a produção de provas a fim de restar esclarecido o fato delituoso, embora essas diligências possam ser indeferidas pela autoridade policial (art. 14 do Código de Processo Penal).

Além disso, para não se beneficiar da demora da conclusão do inquérito policial, sua atividade deve ser claramente protelatória, indevida, realizada de modo a conturbar o encerramento da investigação. Caso contrário, ou seja, se sua atuação tiver por fim o esclarecimento da verdade e se basear em razões de fato e de direito que demonstrem o único intuito de comprovar fatos de seu interesse, nesse caso mesmo sua atuação não justifica a demora na conclusão dos trabalhos policiais.

De outro lado, é preciso que cada caso seja analisado à luz do princípio da razoabilidade, ou seja, que se verifique se a demora na conclusão do inquérito não decorreu de desídia ou outra falta da autoridade policial, além de se analisar se o crime é de solução simples ou complexa, comparando-se o tempo de sua tramitação com a dificuldade em se encontrarem as provas necessárias para concluí-lo.

Ainda sobre o tema do trancamento do inquérito policial pela excessiva duração de sua tramitação, Silva Junior publicou artigo ${ }^{301}$ salientando o seguinte: "Primeiramente, diga-se que o referido inciso LXXVIII, inserido na Constituição Federal pela Emenda Constitucional $\mathrm{n}^{\mathrm{o}} 45$, ao mencionar expressamente o 'âmbito administrativo', parece afastar de forma incontestável que a 'razoável duração do processo' ali aludida se refira exclusivamente a processos judiciais. Nesse diapasão, o inquérito policial, ou mesmo as investigações preliminares que o antecedem, como é o caso concreto existente no texto, entendidos como procedimentos administrativos informativos com a função de subsidiar uma futura e eventual ação penal, estão, sim, submetidos à previsão contida no referido

\footnotetext{
$301 \quad$ SILVA JÚNIOR, Délio Lins e. O trancamento do inquérito policial pela falta de razoabilidade no prazo de sua duração. Boletim do Instituto Brasileiro de Ciências Criminais. São Paulo: Instituto Brasileiro de Ciências Criminais, ano 13, nº 160, p. 4-5, mar. 2006.
} 
artigo, devendo ter uma duração 'razoável'. Com efeito, ousamos chegar a dizer que nos referidos procedimentos administrativos tal imposição se mostra ainda mais importante do que na ação penal em si, pois, nesta, o cidadão que vem tendo mitigadas suas garantias fundamentais ao menos sabe o que está ocorrendo, ao passo que nos inquéritos policiais e investigações a ele preliminares, tudo se passa à sua revelia, sempre às escondidas, razão pela qual devem ser exemplarmente, e mais duramente, reguladas".

Sobre o que seria prazo razoável, assim se manifesta: "Superada tal questão preliminar, resta saber o que seria um tempo razoável de duração para um inquérito policial, ou mesmo para que se investigue preliminarmente, qualquer cidadão. Frente ao flagrante impasse diante de tal tarefa, corroboramos o pensamento de Aury Lopes Junior ao trazer como solução 'ideal' a regra contida no artigo 407.3 do Código de Processo Penal italiano, pela qual extingue-se o feito nos casos em que houver demora excessiva para o julgamento. Pactuamos desse entendimento, porém, enquanto o legislador pátrio não inserir em nosso Código de Processo Penal uma norma como a italiana, que leve a caracterizar, por absoluta previsão legal, constrangimento ilegal a superação indiscriminada, excessiva e sem justificativa concreta a ensejá-la dos prazos para conclusão dos inquéritos policiais, ficam os envolvidos em procedimentos criminais submetidos à 'razoabilidade' dos julgadores e investigadores, essencialmente subjetiva e arbitrária".

Por fim, sustenta como solução para a falta de uma definição legal sobre o prazo razoável a possibilidade de declaração de nulidade dos inquéritos que se prolongarem indevidamente como forma de ser respeitado o dispositivo constitucional.

O Projeto de Código de Processo Penal n. 4.209/2001 previa que ao receber a notícia do crime, a autoridade policial deveria instaurar o inquérito policial no prazo de dez dias e encaminhá-lo ao Ministério Público em vinte dias para indiciado solto e no prazo de dez dias, se preso (artigos $9^{\circ}$ e 10 do Projeto n. 4.209/2001), sendo tais prazos fatais, improrrogáveis, visto que se faltasse alguma diligência para a apuração do crime e da sua autoria, ao encaminhar os autos do inquérito ao Ministério Público, deveria a autoridade policial comunicar este órgão de que existem outras diligências em curso, que deveriam ser 
documentadas em autos suplementares, encaminhando-as ao titular da ação penal pública. ${ }^{302}$ De qualquer modo, o inquérito deveria estar encerrado no prazo máximo de sessenta dias (art. 10 e parágrafo único do Projeto).

Além disso, uma vez remetidos os autos do inquérito policial ao Ministério Público, pelo Projeto eles não mais retornariam à polícia. Assim, não mais ocorreriam os sucessivos pedidos de dilação de prazo para a conclusão do inquérito, o que agilizaria sua tramitação e afastaria o risco de delongas desnecessárias e, também, a sensação de impunidade. ${ }^{303}$

Aliás, referido Projeto previa recurso do ofendido à autoridade policial superior ou representação ao Ministério Público com o objetivo de ser finalizado o inquérito e determinada a responsabilidade da autoridade e de seus agentes. ${ }^{304}$

Dessa forma, é possível o trancamento do inquérito policial quando sua duração, sem solução, puder ser considerada excessiva.

\subsection{Natureza jurídica da decisão de trancamento do inquérito policial e efeitos}

A natureza jurídica da decisão judicial que acolhe o pedido de trancamento do inquérito policial é a de sentença, uma vez que põe fim à investigação e impede o posterior desarquivamento do inquérito policial, ainda que surjam novas provas (Código de Processo Penal, art. 18 e Súmula 524 do Supremo Tribunal Federal).

Portanto, no sistema processual brasileiro a decisão de trancamento do inquérito policial é judicial e impede o reinício das investigações, visto que analisa o mérito, de modo que faz coisa julgada material. Trata-se, pois, de sentença.

Não se confunde a decisão de trancamento com a decisão de mero arquivamento. É verdade que o trancamento do inquérito acarreta como consequência o arquivamento dos

\footnotetext{
302 TUCCI, Rogério Lauria. Investigação criminal no projeto de reforma do código de processo penal. Revista do Advogado. São Paulo: Associação dos Advogados de São Paulo, ano XXIV, $\mathrm{n}^{\circ}$ 78, p. 103-110, set. 2004

Ibidem, p. 105.

$304 \quad$ Ibidem, mesma página.
} 
autos, mas as duas decisões não se confundem, haja vista que os fundamentos e os efeitos são diversos.

Enquanto a decisão de trancamento é judicial, ou seja, uma sentença que analisa o mérito e impede o desarquivamento ainda que com novas provas, a decisão de mero arquivamento é provisória, cautelar ${ }^{305}$ e administrativa para alguns ${ }^{306}$, e faz coisa julgada meramente formal, eis que, se surgirem novas provas o inquérito poderá ser reiniciado e consequentemente poderá ser proposta a ação penal (Código de Processo Penal, art. 18 e Súmula 524 do Supremo Tribunal Federal).

Portanto, a decisão de mero arquivamento está sujeita à clausula rebus sic stantibus, ou seja, pode ocorrer o reinício das investigações - com a propositura da respectiva ação penal - se surgirem novas provas, ao passo que a decisão de trancamento não permite o reinício das investigações, seja no inquérito original, seja em novo inquérito, visto que a decisão está coberta pela coisa julgada material, diferentemente da decisão de mero arquivamento que produz coisa julgada meramente formal.

Pitombo sustenta que mesmo a decisão de arquivamento é sentença, ou seja, decisão judicial, que faz coisa julgada meramente formal, negando o caráter administrativo dessa decisão. Para ele, o arquivamento que não enfrenta o mérito da causa é sentença que faz coisa julgada meramente formal. Já o arquivamento que reconhece a prescrição, ou seja, julga extinta a punibilidade, além de outras hipóteses que enfrentam o mérito da causa, também é sentença que faz coisa julgada formal e material, impedindo o desarquivamento, ainda que diante de novas provas, sendo inaplicável o artigo 18 do Código de Processo Penal e a Súmula 524 do Supremo Tribunal Federal. ${ }^{307}$

Embora o autor fale em arquivamento, também se aplica seu ensinamento para o caso de trancamento, onde é possível reconhecer alguma das causas de extinção da

\footnotetext{
305 COUTINHO, Jacinto Nelson de Miranda. A natureza cautelar da decisão de arquivamento do inquérito policial. Revista de Processo. São Paulo: Revista dos Tribunais, ano 18, n⿳ 70, p. 4958, abr./jun. 1993.

306 JARDIM, Afrânio Silva. Arquivamento e desarquivamento do inquérito policial. Revista de Processo. São Paulo: Revista dos Tribunais, ano IX, nº 35, p. 264-276, abr./jun. 1984.

PITOMBO, Sérgio Marcos de Moraes. Arquivamento do inquérito policial: sua força e efeito. Revista do Advogado. São Paulo: Associação dos Advogados de São Paulo, ano III, nº 11, p. 9-15, out./dez. 1982.
} 
punibilidade e encerrar o inquérito policial prematuramente, com término das investigações.

De fato. Se no transcorrer nas investigações for possível concluir que o fato não existiu, é atípico, o investigado não é seu autor, ocorreu alguma causa de extinção de punibilidade ou há causa de exclusão de antijuridicidade ou culpabilidade, não se pode falar que a decisão de trancamento e respectivo arquivamento esteja sujeita a cláusula rebus sic stantibus. Há quem sustente, contudo, não se falar em sentença ou em coisa julgada, embora admita a impossibilidade de reabertura das investigações após ser arquivado inquérito com fundamento na atipicidade do fato, prescrição ou decadência ${ }^{308}$. No entanto, a despeito desse entendimento diverso, há citação de decisão do Supremo Tribunal Federal, que reconheceu a existência de coisa julgada material à decisão de arquivamento do inquérito policial baseada na atipicidade da conduta, com impossibilidade de reabertura das investigações, seja no inquérito primitivo, seja em novo inquérito policial, nos seguintes termos: "A decisão que determina o arquivamento do inquérito policial, a pedido do Ministério Público, quando o fato nele apurado não constituir crime, produz, mais que preclusão, coisa julgada material, impedindo ulterior instauração de processo que tenha por objeto o mesmo episódio, ainda que a denúncia se baseie em novos elementos de prova". 309

Em verdade, a decisão de trancamento nessas hipóteses fulmina o jus puniendi estatal, e não pode ser o inquérito desarquivado, com posterior propositura da ação penal, ainda que surjam novas provas, ou mesmo ser aberto novo inquérito para investigar o fato anteriormente apurado no inquérito trancado, não se aplicando, portanto, o art. 18 do Código de Processo Penal ou a Súmula 524 do Supremo Tribunal Federal.

Este aspecto ressalta ainda mais a correlação entre a justa causa para o inquérito policial e para a ação penal. Uma vez ausente a justa causa para o inquérito policial, ausente a justa causa para a ação penal.

Por outro lado, a questão terminológica do Código de Processo Penal é questão de fundo, haja vista que o legislador não foi feliz ao definir certas decisões da forma correta.

\footnotetext{
CHOUKR, Fauzi Hassan. Garantias constitucionais na investigação criminal. $3^{\mathrm{a}}$ ed. rev. amp. atual. Rio de Janeiro: Lumen Juris, 2006, p. 166-167.

309 Ibidem, p. 167-168.
} 
O fato de não ter definido a decisão de arquivamento como sentença, mesmo no caso em que é analisado o mérito da causa - hipótese de trancamento-, mas como despacho - art. 18 - não implica em mudança da natureza jurídica desse ato que é, indubitavelmente, sentença. ${ }^{310}$

Também não tem a decisão de trancamento natureza de decisão interlocutória simples ou mista (Código de Processo Penal, art. 800, I), uma vez que não decide questão relativa ao andamento do inquérito ou a questão incidente, prejudicial ao andamento do inquérito extinguindo a "relação processual", já que a decisão interlocutória mista não resolve o mérito da causa como a sentença de trancamento.

A sentença que decide pelo trancamento do inquérito policial, seja em ação penal pública, seja em ação penal privada, deve ser precedida de manifestação do Ministério Público (Código de Processo Penal, art. 257, II), titular da ação penal, na primeira hipótese e fiscal da lei, na segunda.

Além disso, a decisão que determina o trancamento do inquérito policial, assim como aquela que manda arquivá-lo, deve ser fundamentada, sob pena de nulidade ${ }^{311}$ (Constituição Federal, art. 93, IX).

A decisão que declara no inquérito extinta a punibilidade pela decadência, ou seja, decorridos seis meses da data em que o ofendido ou seu representante legal vieram a saber quem é o autor do fato, sem apresentação de representação nos crime de ação penal pública ou sem o oferecimento da queixa nos crimes de ação penal privada, analisa o mérito da causa e faz coisa julgada material, acarretando o trancamento do inquérito policial e seu encaminhamento ao arquivo. ${ }^{312}$

\footnotetext{
PITOMBO, Sérgio Marcos de Moraes. Arquivamento do inquérito policial: sua força e efeito. Revista do Advogado. São Paulo: Associação dos Advogados de São Paulo, ano III, n 11 , p. 9-15, out./dez. 1982.

311 CARVALHO, Salo de. Considerações sobre o arquivamento do inquérito policial: requisitos e controle judicial (estudo de caso). Revista Brasileira de Ciências Criminais. São Paulo: Revista dos Tribunais, ano 18, nº 83, p. 322-349, mar./abr. 2010.

312 COUTINHO, Jacinto Nelson de Miranda. A natureza cautelar da decisão de arquivamento do inquérito policial. Revista de Processo. São Paulo: Revista dos Tribunais, ano 18, n 70, p. 4958, abr./jun. 1993.
} 
A sentença que acolhe a renúncia ao direito de queixa também julga extinta a punibilidade com fundamento no artigo 107, V do Código Penal e também analisa o mérito, de modo que não pode mais ser desarquivado o inquérito trancado por tal decisão.

A decisão que reconhece a prescrição e determina o trancamento do inquérito também analisa o mérito ${ }^{313}$ e julga extinta a punibilidade, impedindo o desarquivamento.

\subsection{5}

\section{O PLS 156/2009 e o juiz de garantias}

O anteprojeto de reforma do Código de Processo Penal, elaborado pela Comissão de Juristas criada pelo Requerimento n. 227, de 2008, do Senado Federal, coordenada pelo Ministro do Superior Tribunal de Justiça Hamilton Carvalhido e cujo Relator-geral foi o Procurador da República Eugênio Pacelli de Oliveira, transformou-se no Projeto de Lei n. 156/2009, em trâmite naquela Casa Legislativa ${ }^{314}$, que traz significativas mudanças no cenário do processo penal brasileiro ${ }^{315}$.

A primeira e clara preocupação da Comissão foi demonstrar a tendência garantista do novo estatuto. Tanto isso é verdade que logo de início, no Livro I, Título I, relativo aos primeiros artigos do anteprojeto, são previstos os princípios fundamentais sobre os quais se assenta o novo processo penal, dentre os quais o do devido processo legal, o da adoção do sistema acusatório e da máxima proteção dos direitos fundamentais.

No tocante à atuação do juiz e com vistas à consolidação do sistema acusatório, cria-se a figura do juiz das garantias (artigos 14 a 17), com competência exclusiva para atuação na fase da investigação e tutela das garantias fundamentais, afastando-se o juiz do processo, responsável pela decisão de mérito, daquela fase, fortalecendo-se o princípio da imparcialidade do julgador e o sistema acusatório. Cabe ao juiz das garantias, assim, fiscalizar o trâmite do inquérito policial e verificar sua adequação à ordem jurídica em vigor.

\footnotetext{
$313 \quad$ Ibidem, p. 50.

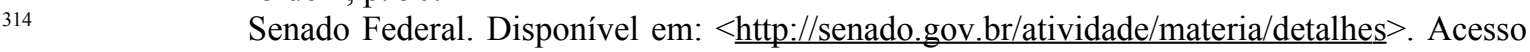
em: 4-7-2012.

315 Exposição de Motivos do Novo Código de Processo Penal. Senado Federal. Disponível em:

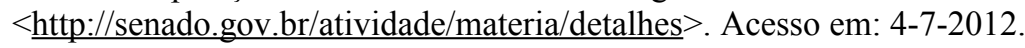


Ainda na fase investigativa, o arquivamento do inquérito policial pode ser requerido pelo Ministério Público e determinado pelo juiz de garantias (artigos 38 e 39), podendo haver controle por parte da vítima se não houver observância dos prazos legais pelo Ministério Público, com possibilidade de propositura de ação penal subsidiária (art. 48).

Quanto ao juiz de garantias, esta figura já existe em outros ordenamentos latinoamericanos e europeus preocupados com a separação das funções de controle do inquérito policial e do julgamento da causa criminal, com vistas a garantir a imparcialidade na hora do julgamento, embora a denominação seja normalmente juiz de instrução, como já foi visto nos itens 1.16 .1 a 1.16.9.

O juiz de garantias tem por fim, como o próprio nome indica, resguardar os denominados direitos fundamentais do investigado durante a fase preliminar que é a do inquérito policial. A ideia principal é a de que o contato do juiz com o material colhido durante a tramitação do inquérito policial lhe retira a imparcialidade necessária para a posterior prolação da sentença, visto que mediante esse contato sua convicção já estaria sendo formada antes mesmo da realização da instrução na fase processual.

Quando um juiz analisa um pedido de interceptação telefônica, por exemplo, terá que averiguar a existência de provas, indícios de autoria e fundadas razões a indicar a necessidade de sua realização. Esse contato com o material colhido durante a investigação acaba por contaminar subjetivamente o juiz responsável pelo julgamento da causa e afasta a ideia de seu distanciamento, afetando sua imparcialidade. ${ }^{316}$ Esse é o sistema que vige hoje, visto que o mesmo juiz que julgará a causa é o responsável pelo controle da legalidade da investigação e análise e deferimento de medidas restritivas de direitos fundamentais, tais como interceptação telefônica, busca e apreensão, quebra de sigilo fiscal e bancário. Está, pois, vinculado, o juiz que atuou na fase preliminar à instrução processual e ao julgamento do processo. ${ }^{317}$

A discussão sobre a atuação do juiz de garantias, hoje, estende-se, inclusive, para o segundo grau de jurisdição e até para as cortes superiores, ou seja, os órgãos de segunda ou

\footnotetext{
MAYA, André Machado. Imparcialidade e processo penal: da prevenção da competência ao juiz de garantias. Rio de Janeiro: Lumen Juris, 2011, p. 219.

GIACOMOLLI, Nereu José. A fase preliminar do processo penal: crises, misérias e novas metodologias investigatórias. Rio de Janeiro: Lumen Juris, 2011, p. 63.
} 
terceira instância que julgaram algum recurso contra decisões proferidas não só pelo juiz de garantias na fase da investigação, mas também pelo da instrução processual ou pelos tribunais inferiores, ou mesmo que analisaram alguma ação impugnativa, como o habeas corpus, estariam com sua imparcialidade viciada, de modo que não poderiam julgar eventuais recursos contra a decisão de mérito. ${ }^{318}$

Assim, com a criação do juiz de garantias, a ele competiria garantir a legalidade da investigação, bem como a observância dos direitos fundamentais da pessoa investigada, exercendo o controle sobre medidas restritivas de tais direitos. Finda a investigação, a outro juiz competirá presidir a instrução processual o qual não teve nenhum contato com os elementos colhidos durante a investigação a fim de ser preservada a sua imparcialidade e materializada a aplicação do sistema acusatório no processo penal.

Desse modo, o juiz de garantias impede os excessos persecutórios e viabiliza a restrição aos direitos fundamentais apenas de forma excepcional. ${ }^{319}$ Essa restrição deve se adequar ao fim buscado, ser necessária e proporcional ao bem jurídico atingido.

A única crítica que se faz ao modelo previsto para a criação do juiz de garantias é que ele não será competente para o juízo de recebimento ou rejeição da acusação, de modo que competirá ao juiz da instrução processual proceder a tal função após a resposta do acusado (art. 274 do projeto), de modo que acabará por ter contato com os elementos colhidos durante a tramitação do inquérito policial, justamente o que se queria evitar com a criação do juiz de garantias. Melhor seria, pois, que a esse coubesse o juízo de valor para o recebimento ou rejeição da peça inicial acusatória, com total desvinculação do juiz da instrução processual com os elementos informativos a fim de preservar sua imparcialidade e evitar a influência das teses das partes litigantes - acusação e defesa. 
O anteprojeto prevê, no artigo 14, uma série de medidas que competem ao juiz de garantias, sem prejuízo de outras que a investigação exigir sua participação durante sua tramitação.

Interessa ao presente estudo o art. 14, IX do projeto que prevê a competência do juiz de garantias para o trancamento do inquérito policial quando não houver fundamento razoável para sua instauração ou prosseguimento.

Importa ressaltar que o art. 15 dispõe ser da competência do juiz de garantias atuar para o controle da legalidade das investigações de toda e qualquer infração penal, à exceção das que são consideradas de menor potencial ofensivo. Evidente. Nessas infrações penais, não há instauração de inquérito policial, mas elaboração de simples termo circunstanciado. Assim, se não há investigação propriamente dita, por consequência, não há necessidade de medidas restritivas de direitos fundamentais, o que afasta a atuação de um juiz de garantias. Quanto às infrações penais de menor potencial ofensivo, atualmente abrangidas pela Lei n. 9.099, de 26-9-1995 - no âmbito estadual - e pela Lei n. 11.313, de 28-6-2006 - no âmbito federal -, o projeto incorpora seus princípios e passa a regulá-lo no procedimento sumaríssimo (artigos 285 a 313 do projeto).

Além disso, o art. 15 também dispõe que a competência do juiz de garantias cessa com a propositura da ação penal. Esse ponto é importante na medida em que, proposta a ação penal e cessada a competência do juiz de garantias, perde sentido eventual pedido de trancamento do inquérito policial, uma vez que o juízo de valor para o recebimento ou rejeição da acusação será efetuado pelo juiz da instrução da causa e as razões para eventual rejeição da acusação poderão ser formuladas na defesa preliminar anterior à decisão do juiz da causa responsável pelo recebimento ou rejeição da acusação.

Outro ponto importante que consta do art. $15, \S \S 1^{\circ}$ e $2^{\circ}$ do projeto é a possibilidade do juiz do processo, após proposta a ação penal, decidir as questões pendentes, além de não estar ele vinculado às decisões do juiz de garantias, podendo reexaminar a necessidade de medidas cautelares em curso. ${ }^{320}$ 
Por fim, cumpre destacar que o art. 16 do projeto impede a atuação do juiz de garantias nas demais fases do mesmo processo penal. Reconhecendo a dificuldade de implementação da figura do juiz de garantias em um país com dimensões continentais como o nosso, que tem inúmeras comarcas com apenas um juiz, o projeto previu, no art. 748 , I que esse impedimento não se aplica às comarcas que tenham apenas um juiz até que a lei de organização judiciária dos respectivos Estados não dispuser sobre sua criação ou outras formas de substituição. Não há, contudo, previsão na redação final do projeto de prazo para que seja criado o juiz de garantias ou outro órgão que cumpra essa substituição para as comarcas com apenas um juiz. ${ }^{321}$

Cumpre consignar, por derradeiro, que todas as conclusões sobre o trancamento do inquérito policial, que passará a ser de competência do juiz de garantias pelo projeto 156/2009, são válidas e aplicáveis ao novo processo penal, seja no tocante aos fundamentos, seja no tocante aos instrumentos adequados para o pedido, que continuarão sendo o habeas corpus ou mera petição dirigida ao juiz de garantias responsável pelo inquérito policial. 


\title{
2. INSTRUMENTOS ADEQUADOS PARA O TRANCAMENTO DO INQUÉRITO POLICIAL
}

\author{
Habeas Corpus
}

Como visto diversas vezes nesse trabalho, o habeas corpus é o instrumento jurídico por excelência para se requerer o trancamento do inquérito policial.

O habeas corpus visa o fim da coação da liberdade de locomoção, ou seja, tutela o direito de ir, vir e ficar.

Não se presta à tutela de outros direitos, haja vista que a eles estão reservados outros instrumentos, tais como mandado de segurança, habeas data e mandado de injunção.

O habeas corpus teve sua origem no $§ 29$ da Magna Carta da Inglaterra, em 15 de junho de 1215 , para a garantia da liberdade física. ${ }^{322}$ Foi o instrumento criado pelos barões e condes do reino da Inglaterra para impedir a continuidade das barbaridades cometidas pelo Rei João-Sem-Terra.

A despeito disso, a garantia tutelada pelo habeas corpus, com o passar dos séculos foi sendo desrespeitada, seja pelos monarcas que se sucederam, seja pelos juízes que a não aplicavam. Diante disso, em 27 de maio de 1679 foi editado o Habeas Corpus Act, espécie de segunda Carta Magna na Inglaterra, que previu o "direito ao mandado" contra a violação da liberdade e que regulamentava o procedimento para seu pedido e concessão. ${ }^{323}$

\footnotetext{
MIRANDA, Pontes de. História e prática do habeas corpus. Atualizado por Vilson Rodrigues Alves. $3^{\mathrm{a}}$ ed. Campinas: Bookseller, 2007, v. 1, p. 35.

$323 \quad$ Ibidem, p. 85.
} 
No Brasil, o habeas corpus surgiu à época do Império com o Decreto de 23 de maio de 1821. Além disso, foi previsto pelos artigos 183 e 184 do Código Criminal de 1830, bem como pelo art. 340 do Código de Processo Penal de 1832, para a proteção da liberdade contra prisão ou constrangimento ilegal. ${ }^{324}$ Não o previu a Constituição de 1824 , embora do teor do artigo 179 , inc. $8^{\circ}$ fosse possível extrair sua existência.

A primeira Constituição brasileira a prever o habeas corpus foi a republicana de 1891 (art. 72, § 22). Seu texto previa que seria concedido habeas corpus sempre que o indivíduo sofresse ou se achasse em iminente perigo de sofrer violência ou coação, por ilegalidade ou abuso de poder. Como sua redação não previa de forma expressa sua função de proteção à liberdade de locomoção, o entendimento era de que ele se prestava à defesa de toda espécie de direito.

A atual Constituição brasileira - de 5 de outubro de 1988 - previu o habeas corpus em seu art. $5^{\circ}$, LXVIII, in verbis: Conceder-se-á habeas corpus sempre que alguém sofrer ou se achar ameaçado de sofrer violência ou coação em sua liberdade de locomoção, por ilegalidade ou abuso de poder.

O Código de Processo Penal em vigor - Decreto-lei n. 3.689, de 3-10-1941 regulamentou o habeas corpus em seus artigos 647 a 667.

Do texto constitucional e do Código de Processo Penal verifica-se que ele é cabível contra violência ou coação à liberdade de locomoção em caso de ilegalidade ou abuso de poder.

Segundo Scarance, "consiste ainda o habeas corpus no instrumento hábil para ser trancado o inquérito policial e é admitido para impedir o indiciamento do investigado. $\mathrm{O}$ pedido de trancamento do inquérito policial é um meio relevante para a reação do imputado. Pode, para requerer o trancamento, sustentar que o fato não existiu, que é atípico, que não houve representação em inquérito por crime de ação penal pública condicionada, que faltou requerimento do ofendido para a instauração do inquérito em 
crime de ação penal privada, que não podia no caso ser atribuída a autoria ao investigado ou que se apurou não ser o indiciado o autor do fato". ${ }^{325}$

\subsubsection{Natureza jurídica}

A natureza jurídica do habeas corpus é de ação constitucional, haja vista que por meio dele é possível provocar a atividade jurisdicional do Estado com o intuito de ser tutelado o direito à liberdade.

Entretanto, dependendo do tipo de provimento judicial que se buscar por meio do habeas corpus, sua natureza jurídica pode variar.

Assim, se o habeas corpus for intentado na forma preventiva, ou seja, para impedir a lesão ou a ameaça ao direito de locomoção, sua natureza será cautelar; se impetrado para corrigir ilegalidade já consumada, ou seja, na forma repressiva, terá ele a natureza jurídica de ação constitutiva, visto que o provimento jurisdicional que o acolhe, concedendo a liberdade ao paciente, o colocará em nova situação, a da liberdade; por fim, se visar o habeas corpus a declaração de não existência de justa causa a fundamentar a restrição da liberdade do paciente, terá natureza declaratória na medida em que tal situação é esclarecida por meio da ordem que o concede. ${ }^{326}$ Pode ainda ter o caráter condenatório quando a autoridade coatora agiu de má-fé e com abuso de poder, à qual será imposta a condenação ao pagamento de custas (art. 653 do Código de Processo Penal). ${ }^{327}$

José Barcelos de Souza fala em outra natureza jurídica que o habeas corpus pode ter: a de habeas corpus processual. Segundo ele, o habeas corpus processual não diz respeito à ação constitucional por meio da qual se reivindica a liberdade de locomoção, mas "à sua face de remédio processual contra a ilegalidade e contra os constrangimentos sem justa causa no processo penal, para o que pode aí ser perfeitamente utilizado ainda que

\footnotetext{
325 FERNANDES, Antonio Scarance. Reação defensiva à imputação. São Paulo: Revista dos Tribunais, 2002, p. 141.

MACHADO, Antônio Alberto. Curso de processo penal. $3^{\mathrm{a}}$ ed. aum. atual. São Paulo: Atlas, 2010, p. 737.

GRINOVER, Ada Pellegrini; GOMES FILHO, Antonio Magalhães; FERNANDES, Antonio Scarance. Recursos no processo penal. $7^{\text {a }}$ ed. rev. atual. São Paulo: Revista dos Tribunais, 2011, p. 273.
} 
o réu não se ache preso nem concretamente ameaçado de prisão". ${ }^{328} \mathrm{O}$ habeas corpus processual seria cabível para fazer cessar constrangimento ilegal decorrente de falta de justa causa por conta da nulidade do processo. Daí porque esta "espécie" de habeas corpus poderia ser usada para trancar ação penal a que falte justa causa, ainda que o réu não se encontre preso ou na iminência de sê-lo. ${ }^{329}$

Daí porque é possível concluir que o habeas corpus processual, na definição de José Barcelos de Souza, pode ser usado para trancar o inquérito policial, afinal de contas, se pode ser manuseado para o mais, o trancamento da ação penal, pode ser utilizado para o menos, o trancamento do inquérito policial.

Tem também o habeas corpus o caráter mandamental, já que se verificada a ilegalidade ou abuso de poder contra a liberdade de locomoção, a autoridade judiciária que o conceder mandará expedir ordem para o cumprimento imediato da decisão a ser cumprida pelo responsável pela coação, sob pena de crime de desobediência (art. 330 do Código Penal). ${ }^{330}$

Sobre a natureza jurídica e os efeitos da decisão de trancamento do processo por meio de habeas corpus, Geraldo Batista de Siqueira abordou a questão em razão de pergunta formulada em concurso de ingresso no Ministério Público goiano ("O Habeas Corpus tranca o processo?"), onde traça alguns aspectos interessantes. ${ }^{331}$

Segundo o autor do estudo, dependendo do provimento jurisdicional que se busca, o habeas corpus pode ter a natureza jurídica de ação ou de verdadeiro recurso.

Quando o remédio constitucional funcionar como medida destinada a impugnar uma decisão, terá a natureza de recurso. Caso a ação penal seja recebida sem lastro nos

\footnotetext{
328 SOUZA, José Barcelos de. Habeas-corpus processual. Boletim do Instituto Brasileiro de Ciências Criminais. São Paulo: Instituto Brasileiro de Ciências Criminais, ano 4, nº 50, p. 3, jan. 1997.

Ibidem, mesma página.

GRINOVER, Ada Pellegrini; GOMES FILHO, Antonio Magalhães; FERNANDES, Antonio Scarance. Recursos no processo penal. $7^{\mathrm{a}}$ ed. rev. atual. São Paulo: Revista dos Tribunais, 2011, p. 273.

SIQUEIRA, Geraldo Batista de. O habeas corpus tranca o processo? In: GARCIA, Maria; PIOVESAN, Flávia (org.). Direitos humanos: instrumentos e garantias de proteção: garantias constitucionais, garantias jurisdicionais e aspectos gerais. Coleção Doutrinas Essenciais. São Paulo: Revista dos Tribunais, p. 311-317, 2011, v. 5.
} 
fatos apurados no inquérito policial, não há justa causa para sua instauração e o habeas corpus será impetrado para trancar o processo atuando, nesse caso, como verdadeiro recurso. Se o habeas corpus é manejado com o único fim de tutelar a liberdade, terá a natureza jurídica de ação. ${ }^{332}$

Em resposta à indagação inicial, o autor do estudo afirma que haverá o trancamento do processo quando a decisão proferida em habeas corpus atingir a relação jurídica anteriormente constituída ao apontar a ocorrência de causa extintiva de punibilidade ou de ausência de suporte fático a sustentar o desenvolvimento processual. Da mesma forma, o habeas corpus tranca o processo quando for hipótese de abolitio criminis. Quando, por exemplo, o habeas corpus tiver por fim o reconhecimento da nulidade do processo, a relação jurídica processual não será trancada, mas renovada, persistindo a persecução penal. $^{333}$ Nessa última hipótese citada, entendemos, contudo, que o trancamento pode ocorrer se, embora a nulidade do processo não encerre a relação jurídica processual, já tenha decorrido o prazo prescricional.

O trancamento do processo ainda ocorreria se fosse reconhecida ausência da autoria e atipicidade do fato. ${ }^{334}$

Portanto, o efeito do trancamento do processo por meio de habeas corpus depende da causa que fundamentar a concessão da ordem. Assim, se o reconhecimento de ausência de justa causa tiver como fundamento a prisão anteriormente decretada, sem atingir a relação jurídica material, não se tranca o processo. Ao contrário, se a ausência de justa causa se fundamentar na atipicidade do fato, por exemplo, não apenas se concede a liberdade ao imputado eventualmente preso, mas também encerra-se a relação jurídica de direito material e haverá o trancamento do processo.

Outra questão interessante é o trancamento da ação penal subsidiária. A ação penal subsidiária é aquela intentada pelo ofendido ou seu representante legal quando o Ministério Público não ajuizar a ação penal pública no prazo de cinco dias, contados do recebimento do inquérito em caso de indiciado preso, ou no prazo de quinze dias, no caso de indiciado solto (Código de Processo Penal, art. 29 - Código Penal, art. 102, § $3^{\circ}$ ).

\begin{tabular}{ll}
\hline 332 & Ibidem, p. 312-313. \\
333 & Ibidem, p. 313-314. \\
334 & Ibidem, p. 316.
\end{tabular}


Uma vez ajuizada a ação penal subsidiária pelo ofendido ou seu representante legal, poderá o Ministério Público aditar a queixa, repudiá-la ou oferecer denúncia substitutiva. Caso o Ministério Público repudie a ação penal subsidiária, requerendo o arquivamento do inquérito policial, não poderá prosseguir a ação penal, salvo se ocorrer a hipótese do artigo 28 do Código de Processo Penal. ${ }^{335}$ Caso haja pedido do Ministério Público para arquivamento do inquérito policial, seja logo após ser intimado da propositura da ação penal subsidiária, seja por decisão do Procurador-Geral na hipótese do art. 28 do Código de Processo Penal, e não ocorra dito arquivamento, pode o interessado intentar habeas corpus para trancar a ação penal subsidiária.

Além disso, não é possível o ajuizamento da ação penal subsidiária em inquérito arquivado, visto que o arquivamento a pedido do Ministério Público faz coisa julgada formal. ${ }^{336}$ Ademais, uma vez arquivado o inquérito a pedido do Ministério Público, a ação penal não pode ser iniciada sem novas provas (Súmula 524 do Supremo Tribunal Federal).

\subsection{3}

\section{Espécies}

Dependendo do provimento jurisdicional buscado com vistas a afastar o constrangimento ilegal contra a liberdade de locomoção, o habeas corpus será repressivo também denominado liberatório - ou preventivo.

Será repressivo (ou liberatório) quando a liberdade de locomoção já foi cerceada, ou seja, quando o constrangimento ilegal já se consumou mediante ilegalidade ou abuso de poder.

Será preventivo quando há ameaça ao direito de locomoção, ou seja, quando o constrangimento ilegal ainda não se consumou. Essa ameaça, contudo, há de ser concreta. Não basta o mero temor, a presunção desmotivada, o receio indevido. Deve haver prova efetiva da possibilidade de restrição à liberdade.

\footnotetext{
335 ARAÚJO, Vivaldo Jorge de; SIQUEIRA, Geraldo Batista de. Do trancamento da ação penal subsidiária. Revista Brasileira de Direito Processual. Uberaba: Vitória Artes Gráficas; Rio 
Em caso de habeas corpus preventivo, expede-se em favor do paciente um salvoconduto $^{337}$, que deverá ser assinado pela autoridade judiciária competente e que tem por fim justamente afastar a possibilidade de prisão arbitrária e desmotivada.

São ao menos quatro os sujeitos do habeas corpus: o paciente, que é a pessoa que sofre ou está ameaçada de sofrer constrangimento ilegal contra seu direito de locomoção, o impetrante, que é quem formula o pedido, a autoridade coatora, que é aquela que praticou ou está prestes a praticar coação ilegal contra a liberdade de locomoção de alguém e, por vezes, o detentor, que é quem somente detém o paciente por ordem da autoridade coatora.

No tocante ao impetrante, pode o habeas corpus ser impetrado por qualquer pessoa, inclusive pelo Ministério Público (art. 654 do Código de Processo Penal). O writ será pedido a favor do próprio impetrante ou de outrem.

Seja impetrado em seu próprio favor, seja em favor de outrem, o beneficiário do habeas corpus será a figura do paciente.

Quando se fala que o habeas corpus pode ser impetrado por qualquer pessoa, querse dizer pelo maior ou pelo menor de idade, pelo nacional ou estrangeiro.

E a pessoa jurídica, pode impetrar habeas corpus em favor de pessoa física?

Sim, notadamente pelo fato de o legislador não ter restringido a legitimidade ativa a certas pessoas, e quando não há restrição legal, não cabe ao intérprete restringir. ${ }^{338}$ Também poderá impetrar habeas corpus em seu próprio favor para trancamento do inquérito policial ou mesmo da ação penal quando for indiciada ou ré.

\footnotetext{
337 MIRABETE, Julio Fabbrini. Processo penal. $7^{\text {a }}$ ed. rev. atual. São Paulo: Atlas, 1997, p. 699.

338 RANGEL, Paulo. Direito processual penal. $17^{\mathrm{a}}$ ed. rev. amp. atual. Rio de Janeiro: Lumen Juris, 2010, p. 976.
} 
Pode, inclusive, o juiz, de ofício, conceder habeas corpus quando verificar que alguém sofre ou está na iminência de sofrer coação ilegal (art. 654, § $2^{\circ}$ do Código de Processo Penal).

Pode ser impetrado habeas corpus contra ato de particular?

Parte da doutrina entende que não. Segundo os que entendem desse modo, somente o ato praticado por autoridade pública tem o condão de ser corrigido por meio de habeas corpus, tendo em vista que os atos praticados por particular contra a liberdade de locomoção da vítima constituem crime, seja de constrangimento ilegal (art. 146 do Código Penal), ameaça (art. 147 do Código Penal), sequestro e cárcere privado (art. 148 do Código Penal) ou de exercício arbitrário das próprias razões (art. 345 do Código Penal). ${ }^{339}$

No entanto, a despeito do aspecto criminoso de tais condutas realizadas pelo particular, o entendimento dominante é o de que é possível a impetração de habeas corpus contra ato praticado pelo particular contra a liberdade de locomoção, visto que o fato de a coação ilegal configurar crime não impede a concessão do remédio heroico em favor de quem a sofre, uma vez que a coação ilegal praticada pela autoridade pública também pode constituir o crime de violência arbitrária e o abuso de poder e isso não impede sua utilização. ${ }^{340}$

Ademais, a proteção do habeas corpus contra ilegalidade ou abuso de poder prevista na Constituição Federal (art. 5\%, LXVIII) não previu nenhuma diferenciação entre o ato do particular ou da autoridade pública.

Por outro lado, tratando-se de questão ligada a direito fundamental, não pode haver interpretação restritiva.

\subsection{5}

\section{Cabimento}

O campo de atuação do habeas corpus é muito grande.

339 TORNAGHI, Hélio. Curso de processo penal. $5^{\text {a }}$ ed. São Paulo: Saraiva, 1988. v. 2, p. 408.

340 MIRABETE, Julio Fabbrini. Processo penal. $7^{\text {a }}$ ed. rev. atual. São Paulo: Atlas, 1997, p. 702. 
Ele é cabível sempre que houver ameaça à liberdade de locomoção, ou mesmo quando esta já se consumou.

É possível a interposição de habeas corpus, inclusive, quando já houver trânsito em julgado da decisão e mesmo para substituir outros recursos. Contudo, no que tange ao seu limite, tem atuação menor do que os recursos, visto que só é admissível se o direito de locomoção estiver sendo violado ou ameaçado de forma induvidosa, clara, sem nenhum tipo de dúvida, eis que não admite exame e valoração de provas, ao contrário dos recursos, de modo que seu campo de discussão é mais restrito do que esses. ${ }^{341}$

A despeito disso, o art. 648 do Código de Processo Penal aponta alguns casos onde há coação ilegal contra a liberdade, não sendo esse rol exaustivo, haja vista que sempre será possível a impetração de habeas corpus para prevenção ou reparação de violação da liberdade.

Como estamos tratando do trancamento do inquérito policial, somente nos interessa o inciso I, que trata da coação ilegal quando não houver justa causa.

Já tratamos da justa causa para verificar se ela existe para sustentar a instauração e o prosseguimento do inquérito policial.

Evidentemente, há ligação direta da justa causa para a instauração do inquérito policial com a necessidade de justa causa para seu prosseguimento, na medida em que se esta não se fizer presente, estará configurada a sua ausência e, em consequência, a hipótese será de coação ilegal a sustentar seu trancamento por meio de habeas corpus com fundamento no art. 648, I do Código de Processo Penal.

E o que é justa causa? É a causa prevista em lei para fundamentar a restrição à liberdade de locomoção do indivíduo, ou seja, aquela que esteja conforme o Direito.

341 ARANHA, Adalberto José Q. T. de Camargo. Dos recursos no processo penal. $3^{\mathrm{a}}$ ed., rev. atual. São Paulo: Saraiva, 2010, p. 353. 
Mais precisamente, no dizer de Pontes de Miranda, justa causa "é a causa que, pelo direito, bastaria, se ocorresse, para a coação". 342

Ao que nos interessa, já foram citadas hipóteses que fundamentam o trancamento do inquérito policial, tais como não ser evidentemente o investigado o autor da infração, atipicidade da conduta, não existência de crime, prescrição, falta de representação para seu início nos crimes de ação penal pública condicionada ou de requerimento nos de ação penal privada, reconhecimento do princípio da insignificância no caso concreto - que exclui a tipicidade do delito - ou mesmo a falta de conclusão do inquérito policial em tempo razoável, com desrespeito ao princípio constitucional da duração razoável do processo, aplicável ao inquérito policial, na forma do art. $5^{\circ}$, LXXVIII da Constituição Federal.

É possível o juiz trancar de ofício o inquérito policial? Entendemos que sim.

É muito comum que em caso de indiciado solto (e mesmo se ainda não há indiciado) haver pedido da autoridade policial para dilação de prazo do inquérito com fundamento no art. 10, $\S 3^{\circ}$ do Código de Processo Penal.

Nessa hipótese, após o encaminhamento do inquérito policial ao Ministério Público, verificando a autoridade judiciária, por exemplo, a atipicidade do crime investigado, poderá trancá-lo independentemente de existência de pedido nesse sentido em habeas corpus, afinal de contas não há justa causa para a continuidade das investigações, já que não há nenhum sentido a tramitação do inquérito se ao final se concluir que o fato investigado é atípico.

Nesse mesmo caso de instauração de inquérito policial para investigação de fato atípico, se houver pedido do indiciado para seu trancamento, razão maior haverá para sua concessão. Se é possível a autoridade judiciária conceder a ordem de habeas corpus de ofício (art. 654, $\S 2^{\circ}$ do Código de Processo Penal) decretando o fim das investigações, por que não poderia ocorrer essa situação a pedido do paciente?

$\overline{342}$ MIRANDA, Pontes de. História e prática do habeas corpus. Atualizado por Vilson Rodrigues Alves. 3 ${ }^{\mathrm{a}}$ ed. Campinas: Bookseller, 2007, v. 2, p. 172. 
Portanto, cabe habeas corpus para o trancamento do inquérito policial quando não houver justa causa para seu prosseguimento e o fundamento é o art. 648, I do Código de Processo Penal, inclusive se determinado de ofício pela autoridade judiciária, na forma do art. 654, $\S 2^{\circ}$ do Código de Processo Penal.

E se o inquérito policial ainda não foi instaurado para se investigar, por exemplo, um crime cuja pretensão punitiva estatal esteja prescrita, é possível a concessão de habeas corpus preventivo para impedir sua instauração?

Entendemos que sim. Mas a hipótese não trata do trancamento do inquérito policial e foge aos interesses do presente estudo. De toda forma, essa hipótese deve se basear em fato concreto e iminente que demonstre a provável instauração do inquérito.

De outro lado, é possível a concessão de habeas corpus preventivo quando não houver justa causa para o provável indiciamento do paciente no inquérito policial, quando ele não for evidentemente o autor da infração penal, mas aqui também não se trata, mais uma vez, de trancamento de inquérito, visto que este terá sua regular tramitação, sem a possibilidade de indiciamento do paciente, ao passo que só se tranca aquilo que já tiver se iniciado.

$\mathrm{O}$ art. 654, $\S 1^{\circ}$ do Código de Processo Penal traça os requisitos da petição de habeas corpus.

Deve a petição conter o nome da pessoa que sofre ou está ameaçada de sofrer violência ou coação (art. 654, $\S 1^{\circ}, a$ do Código de Processo Penal), ou seja, o nome do paciente.

O nome da autoridade coatora deve constar do pedido (art. 654, $\S 1^{\circ}$, a, segunda parte do Código de Processo Penal). Poderá ser autoridade pública ou particular. Por outro lado, a questão pertinente à autoridade coatora será melhor analisada no item 2.1.8, quando 
será analisada a questão da competência para apreciação do habeas corpus para o trancamento do inquérito policial.

É preciso que o pedido esclareça a declaração da espécie de constrangimento na hipótese de habeas corpus repressivo ou liberatório, ou as razões em que se funda o temor em caso de habeas corpus preventivo (art. 654, $\S 1^{\circ}, b$ do Código de Processo Penal).

Deve a petição ser assinada pelo impetrante, que pode ser terceira pessoa ou o próprio paciente, ou a seu rogo, quando não souber ou puder escrever, com indicação das respectivas residências (art. 654, $\S 1^{\circ}, c$ do Código de Processo Penal). Não se admite, destarte, pedido apócrifo ou anônimo. ${ }^{343}$

Assim, o impetrante não precisa ter capacidade postulatória, visto que o próprio Código de Processo Penal, bem como o art. $1^{\circ}$, $\S 1^{\text {o }}$ da Lei n. 8.906, de 4-7-1994 (Estatuto da Ordem dos Advogados do Brasil) dispensam a presença do advogado para requerer habeas corpus.

Embora não haja previsão legal, é intuitivo que deva a petição ser instruída com documentos que comprovem a coação ilegal já consumada ou prestes a ocorrer.

Por outro lado, o habeas corpus pode ser impetrado por petição, telegrama, telex ou fax e, nesse último caso, a petição e os documentos originais deverão ser juntados aos autos no prazo de 5 dias (Lei n. 9.800/99). ${ }^{344}$

2.1.7

\section{Procedimento}

Em primeiro grau de jurisdição, o pedido deve atender aos requisitos da petição inicial apontados no item anterior, sob pena de indeferimento liminar caso intimado o impetrante e ele não venha a sanar os vícios respectivos.

\footnotetext{
G43 GRINOVER, Ada Pellegrini; GOMES FILHO, Antonio Magalhães; FERNANDES, Antonio Scarance. Recursos no processo penal. $7^{\mathrm{a}}$ ed. rev. atual. São Paulo: Revista dos Tribunais, 2011, p. 286.

344 CARVAlHO, Djalma Eutímio de. Curso de processo penal. $2^{\mathrm{a}}$ ed. rev. atual. Rio de Janeiro: Forense, 2009, p. 696-697.
} 
Ao receber a petição inicial, o juiz poderá determinar que o preso lhe seja apresentado em dia e hora que designar, caso, evidentemente, se trate de habeas corpus repressivo (ou liberatório).

Como estamos tratando de habeas corpus para trancamento do inquérito policial, é possível que o paciente esteja preso em virtude de prisão em flagrante (artigos 301 e 302 do Código de Processo Penal). Assim, a providência determinada pelo juiz para que o preso lhe seja apresentado em dia e hora que designar (art. 656 do Código de Processo Penal) pode ocorrer nesse caso.

É possível que a petição inicial de habeas corpus contenha pedido de liminar. Caso o juiz verifique pelos documentos juntados que seja evidente a ilegalidade da coação (art. $660, \S 2^{\circ}$ do Código de Processo Penal), poderá conceder a liminar, antecipando os efeitos do provimento final que, no caso do trancamento, se realiza pela suspensão do andamento do inquérito policial, do indiciamento, do interrogatório policial ou da realização de algum ato de prova ainda não realizado até que haja o provimento jurisdicional definitivo, o que ocorrerá com a concessão da ordem.

A apresentação do preso só não se realizará se estiver acometido de grave enfermidade, não estiver sob a guarda da pessoa indicada como detentora ou se não tiver sido determinada pelo juiz. Em caso de enfermidade, poderá o juiz ir até o local onde se encontra o paciente (art. 657 do Código de Processo Penal).

Caso seja determinada a apresentação do preso pelo juiz, se não ocorrer uma das hipóteses do art. 657 do Código de Processo Penal e não for ele apresentado, será expedido mandado de prisão contra o detentor, sem prejuízo de processo por crime de desobediência (art. 330 do Código Penal), e o juiz providenciará que o preso seja tirado da prisão e apresentado em dia e hora que designar (art. 656 do Código de Processo Penal).

Por outro lado, o carcereiro, o diretor da prisão, o escrivão, o oficial de justiça ou a autoridade que embaraçar ou procrastinar a expedição da ordem de habeas corpus, as informações sobre as causas da prisão, a condução e apresentação do paciente, ou sua soltura, sofrerá multa, sem prejuízo das penas em que incorrer (art. 655 do Código de Processo Penal). 
Haja ou não pedido de liminar e uma vez presentes os pressupostos processuais e condições da ação, poderá o juiz pedir informações à autoridade coatora no prazo que marcar. Após tal providência ou sem ela, poderá ser designada audiência para oitiva de testemunhas e interrogatório do paciente, decidindo o juiz, a seguir, no prazo de 24 horas (art. 660 do Código de Processo Penal).

No tocante a questão da dilação probatória, tendo em vista o aspecto sumário do procedimento do habeas corpus, deve-se entender que a designação de audiência para a oitiva de testemunhas é medida excepcional. A despeito disso, como esclarece Constantino, “é possível que o impetrante se depare com a dificuldade, ou até impossibilidade, de provar o constrangimento ilegal. Por exemplo: Uma prisão clandestina. Nestas condições, se declarações assinadas por testemunhas não servirem para atestar a idoneidade da informação, certamente os seus testemunhos servirão. Ora, nestes casos excepcionais é de se admitir a instrução para colheita de prova testemunhal". ${ }^{345}$

De fato. Tomando-se como exemplo a hipótese de impetração de habeas corpus para trancamento do inquérito policial instaurado contra o paciente, sob o fundamento de não ser ele o autor da infração penal, não sendo possível demonstrar esta circunstância por um documento específico que comprove que no dia e hora do delito o paciente se encontrava em uma reunião em outra cidade da qual participaram diversas pessoas, nada impede a oitiva delas para esclarecer esse fato, que necessariamente acarretará a concessão da ordem para o fim de trancar o inquérito policial e encerrar as investigações contra o paciente.

Lembre-se que "seria equívoco grave pensar diferente quando está em jogo uma garantia de direito fundamental". 346

Portanto, no tocante à instrução probatória para produção de provas relativas a fatos relevantes para o acolhimento do pedido de trancamento do inquérito policial, não há a

\footnotetext{
345 CONSTANTINO, Lúcio Santoro de. Recursos criminais, sucedâneos recursais criminais e ações impugnativas autônomas criminais. $4^{\mathrm{a}}$ ed. rev. amp. atual. Porto Alegre: Livraria do Advogado, 2010, p. 338.

346 Ibidem, mesma página.
} 
menor dúvida de que ela pode ser determinada pelo juiz para analisar o pedido de trancamento com maior certeza e segurança.

O Ministério Público não precisa oferecer parecer em habeas corpus em primeiro grau de jurisdição, mas se o fizer não há nenhuma nulidade.

Caso o juiz verifique a cessação da violência ou coação ilegal, julgará prejudicado o pedido (art. 659 do Código de Processo Penal), o que no caso de pedido de trancamento ocorreria se tiver sido anteriormente determinado o arquivamento do inquérito policial. Caso contrário, se ficar evidenciada a falta de justa causa para a instauração do inquérito policial e sua continuidade, o juiz concederá a ordem para trancá-lo, remetendo cópia da decisão à autoridade policial (art. 660, $\S 5^{\circ}$ do Código de Processo Penal), intimando o impetrante e o Ministério Público ${ }^{347}$. Além disso, se não tiver sido concedida liminar, mandará colocar o paciente imediatamente em liberdade, determinando a expedição de alvará de soltura em seu favor. O paciente só não será colocado em liberdade se por outro motivo deva ser mantido na prisão (art. 660, § $1^{\circ}$ do Código de Processo Penal).

É possível a reiteração de habeas corpus quando o fundamento for diverso do anteriormente impetrado. ${ }^{348}$ Tome-se como exemplo habeas corpus impetrado para o trancamento do inquérito policial sob o fundamento de atipicidade da conduta. Caso não seja acolhida essa tese pelo juiz, nada impede que seja impetrado novo habeas corpus, mas agora sob o fundamento de extinção da punibilidade pela prescrição. Veja-se que os fundamentos são diversos para pleitear o trancamento do inquérito, motivo pelo qual é possível sua reiteração.

Em segundo grau de jurisdição, além dos dispositivos do Código de Processo Penal, é preciso verificar o regimento interno dos Tribunais para se aferir questões relativas à competência interna. Além disso, devem ser verificadas as normas de competência nas Constituições estaduais e na Constituição Federal quando decorrerem de foro privilegiado por prerrogativa de função. E a questão da competência decorrerá necessariamente da análise da autoridade considerada coatora, dada a relação entre tais matérias.

\footnotetext{
347 CARVALHO, Djalma Eutímio de. Curso de processo penal. $2^{\text {a }}$ ed. rev. atual. Rio de Janeiro: Forense, 2009, p. 698.

CONSTANTINO, Lúcio Santoro de. Recursos criminais, sucedâneos recursais criminais e ações impugnativas autônomas criminais. $4^{\mathrm{a}}$ ed. rev. amp. atual. Porto Alegre: Livraria do Advogado, 2010, p. 340.
} 
De qualquer modo, a petição inicial deve conter os mesmos requisitos daquela que se apresenta em primeiro grau de jurisdição e ser instruída com a prova do constrangimento ilegal a que está sendo submetido ou que está por ser submetido o paciente.

Uma vez distribuído o pedido, será encaminhado ao órgão competente (art. 661 do Código de Processo Penal). Caso o pedido não preencha os requisitos para seu conhecimento, o Presidente do Tribunal respectivo mandará o impetrante preenchê-lo, logo que lhe for apresentado (art. 662, segunda parte do Código de Processo Penal). Se o Presidente entender que a hipótese é de rejeição liminar ante a impossibilidade de ser sanado o vício, encaminhará o pedido ao Tribunal, Câmara ou Turma para deliberar a respeito (art. 663 do Código de Processo Penal).

É possível a concessão de liminar em favor do paciente logo que receber a petição inicial, e para isso é preciso que haja periculum in mora e o fumus boni iuris. Caso seja negada a liminar, se não houver previsão nos regimentos internos dos Tribunais, não caberá agravo regimental. Contudo, é possível, em hipóteses excepcionais, a impetração de habeas corpus em Tribunal Superior, se houver, para a concessão da liminar negada no Tribunal de origem ${ }^{349}$, tendo em vista o teor da Súmula 691 do Supremo Tribunal Federal: Não compete ao Supremo Tribunal Federal conhecer de habeas corpus impetrado contra decisão do relator que, em habeas corpus requerido a tribunal superior, indefere a liminar. Diante desse enunciado, verifica-se que a impetração de novo habeas corpus para pleitear liminar não concedida no tribunal de origem é medida excepcional, mas é possível, por exemplo, quando atacar os eventuais vícios da decisão que negou a liminar, ou mesmo quando a decisão proferida pelo tribunal de origem colidir com entendimento sedimentado em tribunal superior ou no Supremo Tribunal Federal, ou mesmo se a decisão denegatória de liminar for manifestamente ilegal.

Havendo ou não pedido de liminar, o relator pode determinar que a autoridade coatora preste informações (art. 662 do Código de Processo Penal). Com as informações ou sem elas, quando dispensada, o pedido será encaminhado ao Ministério Público pelo 
prazo de 2 dias (Decreto-lei n. 552, de 25-4-1969). A seguir, o julgamento do habeas corpus será realizado na primeira sessão, salvo se não for possível por motivo justo, caso em que será julgado na sessão seguinte (art. 664 do Código de Processo Penal). A decisão será tomada por maioria de votos. Em caso de empate, prevalece a decisão mais favorável ao paciente (art. 664, parágrafo único do Código de Processo Penal).

\subsubsection{Autoridade coatora para fins de ajuizamento de habeas corpus e competência}

\subsubsection{1}

\section{Autoridade policial como coatora}

Como vimos no item 1.8.1, nos crimes de ação penal pública incondicionada, o inquérito policial terá inicio de ofício, mediante requisição da autoridade judiciária ou do Ministério Público ou mediante requerimento do ofendido ou de quem tiver qualidade para representá-lo. Além disso, nos crimes de ação penal pública condicionada, somente terá início o inquérito se ofertada a representação do ofendido ou de seu representante ou por requisição do Ministro da Justiça. Qualquer do povo que tiver conhecimento de crime de ação pública poderá comunicar o fato à autoridade policial, verbalmente ou por escrito e aquela, verificando a procedência das informações, mandará instaurar inquérito (art. $5^{\circ}$ do Código de Processo Penal).

Nos crimes de ação penal privada, o inquérito não poderá ser iniciado sem o requerimento de quem tenha qualidade para intentá-la (art. $5^{\circ}, \S 5^{\circ}$ do Código de Processo Penal).

$\mathrm{Na}$ hipótese de o inquérito ter início por determinação da autoridade policial, seja por conhecimento pessoal, por comunicação de qualquer do povo, mediante requerimento ou representação do ofendido, será ela a autoridade coatora. Quando isso ocorrer, a competência para o conhecimento e julgamento do habeas corpus com vistas ao trancamento do inquérito policial será do juiz de primeiro grau.

Contudo, é preciso fazer um esclarecimento: uma coisa é a requisição de instauração de inquérito pelo juiz ou pelo Ministério Público, outra coisa é o 
encaminhamento de peças à autoridade policial para conhecimento e eventuais providências. A primeira hipótese é de ordem, determinação a ser atendida pela autoridade policial, ao passo que a segunda não, de modo que no último caso, fica a critério do delegado a abertura do inquérito, razão pela qual, nessa segunda hipótese, seria ele delegado a autoridade coatora ${ }^{350} \mathrm{e}$, portanto, a competência para o processamento e julgamento do habeas corpus para trancar o inquérito policial também será do juiz de primeiro grau. Na segunda hipótese, a ordem partiu de uma daquelas autoridades, que passariam a ser consideradas coatoras, modificando a competência como veremos nos próximos itens.

Greco Filho discorda desse último entendimento. Para ele, ainda que a requisição se trate de uma ordem que não pode deixar de ser atendida, para fins de habeas corpus, em qualquer caso, a instauração do inquérito policial pela autoridade policial incorpora eventual ilegalidade, passando a ser considerada autoridade coatora porque é o seu ato que concretiza a lesão ou ameaça de lesão à liberdade de locomoção. ${ }^{351}$

Da mesma forma, a autoridade policial deve ser considerada coatora na hipótese de despachos de mero expediente do juiz em inquéritos já instaurados por aquela autoridade, como naqueles em que concede mais prazo para sua conclusão ou determina vista ao Ministério Público, uma vez que em tais despachos não há juízo implícito de legalidade do procedimento. ${ }^{352}$ Nessa hipótese, a competência para o julgamento do habeas corpus para o trancamento do inquérito policial será do juiz de primeiro grau.

No mesmo sentido a lição de Scarance: “A determinação da autoridade coatora competente para julgar o habeas corpus deve levar em conta a autoridade que, por meio de juízo hipotético, atribui o fato à pessoa investigada. Normalmente, é a autoridade policial, porque a ela incumbe instaurar o inquérito e indiciar a pessoa suspeita. O juiz ou o promotor será a autoridade coatora quando requisitar a instauração do inquérito e apontar o provável autor do fato delituoso, pois estará realizando ato de imputação. Se o juiz ou o

\footnotetext{
350 BATISTA, Weber Martins. Trancamento de inquérito policial. Revista Forense. Rio de Janeiro: Forense, ano 90, no 328, p. 101-104, out./dez. 1994.

GRECO FILHO, Vicente. Manual de processo penal. $8^{\mathrm{a}}$ ed. rev. amp. atual. São Paulo: Saraiva, 2010, p. 85.

352 BATISTA, Weber Martins. Trancamento de inquérito policial. Revista Forense. Rio de Janeiro: Forense, ano 90, nº 328, p. 101-104, out./dez. 1994.
} 
promotor apenas encaminhar peças ao delegado para que tome as providências cabíveis, não realizou o juízo atributivo da imputação, ou seja, não atribuiu o fato a ninguém". ${ }^{353}$

\subsubsection{Juiz como autoridade coatora}

É possível que a instauração do inquérito policial decorra de requisição do juiz de primeiro grau, nos termos do art. $5^{\circ}$, II do Código de Processo Penal.

Esta requisição não pode deixar de ser atendida pela autoridade policial, salvo flagrante ilegalidade.

Quando isso ocorrer, será competente para a apreciação do habeas corpus para o trancamento do inquérito policial o Tribunal de Justiça, se a instauração de inquérito se der no âmbito da polícia civil, ou do Tribunal Regional Federal, se aquela ocorrer no âmbito da polícia federal. Neste sentido: RT 544/359, 555/374, 558/340; RTJ 87/832.

\subsubsection{3}

\section{O ministério público como autoridade coatora}

Questão mais controvertida sobre a competência para o processamento e o julgamento do habeas corpus diz respeito à instauração do inquérito policial se a autoridade coatora for o Ministério Público.

Houve entendimento de que o Ministério Público nunca seria autoridade coatora para fins de pedido de habeas corpus. Quem defendia tal posicionamento sustentava que se houvesse inquérito a autoridade coatora seria a autoridade policial, se houvesse ação penal a autoridade coatora seria o juiz. Há jurisprudência neste sentido: RT 362/98, 414/62; RTJ 58/388; Justitia, vol. 84/127.

353 FERNANDES, Antonio Scarance. Reação defensiva à imputação. São Paulo: Revista dos Tribunais, 2002, p. 142. 
Contudo, segundo Batista "o que a maioria acolhe é a idéia de que, se o inquérito policial foi instaurado mediante requisição do MP, este é a autoridade coatora". ${ }^{354} \mathrm{O}$ fundamento é igual àquele utilizado para concluir que o juiz é autoridade coatora: a requisição da abertura do inquérito policial com base no artigo $5^{\circ}$, II, do Código de Processo Penal, uma vez que se trata de ordem, exigência, imposição, não restando alternativa à autoridade policial senão sua instauração, é uma ordem que deve ser atendida, ainda que tal requisição seja encaminhada ao delegado por intermédio do juiz.

Da mesma forma que explicamos para o caso do juiz, o órgão do Ministério Público não pode ser considerado autoridade coatora quando encaminhe peças à autoridade policial para que ela "tome as providências que entender cabíveis", ou quando requisitar a abertura de inquérito para apurar um certo fato criminoso, sem apontar seu provável autor. Nesta situação, se houver indiciamento abusivo por parte da autoridade policial, ante a ausência de indícios de autoria, ela será a autoridade coatora. ${ }^{355}$

No caso de ser o Ministério Público a autoridade coatora, a competência para o processamento e julgamento do habeas corpus é do tribunal que seria competente para o julgamento de crimes praticados por seus membros. Neste sentido: Justitia 97/326.

Contudo, há quem sustente tese diversa. Ao combater tal entendimento, Batista assim se manifesta: "acontece que, nas hipóteses mencionadas, a autoridade coatora não está sendo processada criminalmente. Ao apreciar o pedido de habeas corpus, o juiz de primeiro grau não está julgando o promotor, não está decidindo crime por ele praticado daí não se aplicar ao caso a regra do art. 87 do C. Pr. Pen., mas as normas do art. 650 e seus incisos, do mesmo Código". E conclui que “o equívoco está em confundir julgamento do órgão do MP, com julgamento de ato praticado pelo MP, no exercício de suas funções, no processo ou visando ao processo". Além disso, "como está em acórdão do TJSP, nenhuma disposição legal atribui ao órgão de segundo grau competência para conhecer e decidir pedidos de habeas corpus onde se aponte como coator o representante do MP. Ao juiz perante quem oficiam os promotores públicos, no primeiro grau, cabe examinar e

\footnotetext{
354 BATISTA, Weber Martins. Trancamento de inquérito policial. Revista Forense. Rio de Janeiro: Forense, ano 90, no 328, p. 101-104, out./dez. 1994.

$355 \quad$ Ibidem, p. 104.
} 
decidir sobre atos que estes venham a praticar e que importem em constrangimento (JUTA, 95/412)". 356

Não é esse, contudo, o entendimento que sustentamos. A competência para o processamento e julgamento do habeas corpus, quando a autoridade coatora for o Ministério Público, que requisitou a instauração de inquérito policial, é do tribunal que seria competente para julgar os crimes cometidos por seus membros. Assim, da mesma forma que para o juiz como coator, se este for órgão do Ministério Público, será competente para o julgamento do habeas corpus o Tribunal de Justiça (em caso da justiça estadual) ou o Tribunal Regional Federal (em caso de justiça federal). Neste sentido: Superior Tribunal de Justiça, 6 ${ }^{\mathrm{a}}$ Turma, Recurso Especial n. 77.710-SP, relator Ministro Anselmo Santiago, votação unânime, j. 27-10-1997, DJU 17.11.1997.

\subsubsection{Sentença e efeitos}

A Constituição Federal determina que todas as decisões do Poder Judiciário sejam fundamentadas, sob pena de nulidade, ou seja, tanto as decisões proferidas em primeiro grau - sentenças - quanto as proferidas em segundo grau, seja de forma originária ou recursal - acórdãos - devem apresentar a fundamentação utilizada para a sua conclusão (art. 93, IX).

Por outro lado, as sentenças devem conter o relatório, a fundamentação e o dispositivo (art. 381 do Código de Processo Penal). Excetuam-se as sentenças proferidas nos Juizados Especiais Criminais, onde o relatório é dispensado (art.81, $\S 3^{\circ}$ da Lei $n$. 9.099, de 26-9-1995).

No caso de habeas corpus para o trancamento do inquérito policial, o efeito buscado é a liberdade de locomoção. Quando o indiciado está preso durante a tramitação do inquérito policial que se quer trancar, busca-se a concessão de uma ordem no habeas corpus para a garantia de sua liberdade de locomoção, bem como o próprio trancamento, com encerramento das investigações; quando o indiciado está solto, mas por conta da tramitação do inquérito corre o risco de sofrer prisão ilegal, a ordem por ele buscada visa o 
salvo-conduto, impedindo a prisão, além do próprio trancamento, de forma idêntica à do indiciado preso.

Como já dito no transcorrer desse estudo, a decisão que determina o trancamento do inquérito policial, seja ela tomada em habeas corpus em primeiro grau de jurisdição, seja em segundo grau, ou mesmo em sede recursal, faz coisa julgada material e não pode ser rediscutida em novo inquérito policial ou ação penal, ainda que diante de novas provas (art. 18 do Código de Processo Penal e Súmula 524 do Supremo Tribunal Federal). Há quem entenda, contudo, que se a decisão do trancamento decorre do reconhecimento de falta de elementos de autoria não há análise do mérito e se houver novas provas, fica autorizada a retomada do inquérito policial. ${ }^{357}$ Acontece, porém, que não se pode trancar inquérito policial por mera falta de elementos de autoria, mas quando há certeza de que o investigado não seja seu autor. Daí que essa decisão faz coisa julgada material.

Em caso de denegação da ordem, é possível a renovação do pedido de trancamento de inquérito policial em habeas corpus se o fundamento for diverso do anterior. Assim, se a ordem foi denegada em pedido de trancamento com fundamento na atipicidade do fato, nada impede que seja impetrado novo habeas corpus para o trancamento do inquérito policial com fundamento na prescrição da pretensão punitiva. Dessa forma, a decisão denegatória de habeas corpus não faz coisa julgada, salvo se o novo pedido for mera reiteração de anterior.

Nada impede que os temas decididos em habeas corpus sejam reapreciados por meio de outros recursos ou revisão criminal.

\subsubsection{Recursos da decisão proferida em habeas corpus para o trancamento do inquérito policial}

A decisão proferida em habeas corpus, como qualquer outra, está sujeita a controle por via recursal. Daí a necessidade de se dar ciência ao impetrante, ao paciente e ao Ministério Público, visto que todos estes têm interesse processual e legitimidade para 
recorrer da decisão proferida em habeas corpus, os primeiros em caso de denegação e o último em caso de concessão. Há entendimento de também poder recorrer a autoridade coatora em caso de denegação se ela tiver sido condenada ao pagamento de custas por ter agido de má-fé ou com abuso de poder (art. 653 do Código de Processo Penal). ${ }^{358}$

Contra as sentenças proferidas em habeas corpus cabe recurso em sentido estrito (art. 581, X do Código de Processo Penal). Se a decisão for de juiz de direito compete seu conhecimento e julgamento ao Tribunal de Justiça; se for de juiz federal, a competência é do Tribunal Regional Federal a que estiver vinculado o juiz federal de primeiro grau.

O Código de Processo Penal previu que o juiz que concedesse a ordem deveria recorrer de oficio (art. 574, I). Na verdade, não se trata de recurso propriamente dito, visto que não interposto voluntariamente pelos interessados, mas de condição de eficácia da sentença, que só transitaria em julgado após confirmação pela superior instância.

No entanto, compete aos interessados recorrer contra as decisões que lhes são desfavoráveis. Além disso, essa disposição ainda fere o princípio da imparcialidade do juiz, que ficaria obrigado a recorrer de sua própria decisão que concede a ordem, em evidente desfavor do paciente, ainda mais diante da hipótese de ausência de recurso pelo Ministério Público. Sendo assim, esse recurso necessário, em nossa visão, não foi recepcionado pela Constituição Federal de 1988, uma vez que afastou o processo inquisitivo para acolher o processo acusatório (art. $5^{\circ}$, LV e 129, I).

De outro lado, existem também os recursos previstos na Constituição Federal contra as decisões proferidas em habeas corpus.

Assim, as decisões proferidas em habeas corpus em única instância pelos Tribunais Superiores comportam o recurso ordinário dirigido ao Supremo Tribunal Federal, quando denegada a ordem (art. 102, II, $a$, da Constituição Federal), ou ao Superior Tribunal de Justiça, quando a decisão for proferida em única ou última instância pelos Tribunais Regionais Federais ou pelos Tribunais dos Estados e do Distrito Federal (art. 105, II, $a$, da Constituição Federal), também quando denegatória a decisão. Pode-se acrescentar a essa 
hipótese de cabimento de recurso ordinário dirigido ao Supremo Tribunal Federal e ao Superior Tribunal de Justiça na hipótese de não conhecimento do habeas corpus ou quando julgado prejudicado. Neste sentido: RT 640/385.

A hipótese acima tem ligação direta com o foro por prerrogativa de função. Assim, os Prefeitos Municipais são julgados pelos Tribunais de Justiça dos Estados (art. 29, X da Constituição Federal). Quando impetrarem habeas corpus para o trancamento do inquérito policial contra si instaurados perante o Tribunal de Justiça, se denegatória a decisão, poderão interpor recurso ordinário perante o Superior Tribunal de Justiça para revisão do julgado.

Em caso de concessão da ordem, é cabível o recurso extraordinário dirigido ao Supremo Tribunal Federal (art. 102, III da Constituição Federal) e o recurso especial dirigido ao Superior Tribunal de Justiça (art. 105, III da Constituição Federal), desde que atendidos os demais requisitos constitucionais.

\subsection{Petição dirigida ao juiz competente para praticar atos no inquérito}

Embora o habeas corpus seja o instrumento mais adequado para o pedido de trancamento do inquérito policial, não há nada que impeça a formulação do pedido em simples petição dirigida ao juiz competente para praticar atos no inquérito policial.

O pedido de trancamento do inquérito policial por meio de petição deverá ser distribuído a um dos juízes com competência criminal do lugar onde tramitar a investigação criminal, salvo se já tiver sido distribuído o inquérito sem conclusão e com pedido de dilação de prazo ou se algum dos juízes já tiver praticado algum ato anterior no inquérito, hipótese em que estará prevento, devendo a ele ser remetido o pedido (Código de Processo Penal, art. 83).

Entendemos que o requerimento de trancamento por petição só será possível em primeiro grau de jurisdição, haja vista que, em segundo grau de jurisdição e nos Tribunais Superiores, o mais adequado é formular o pedido por meio de habeas corpus. 
Por outro lado, tudo o que se falou sobre os requisitos para o pedido de habeas corpus, seja no tocante à autoridade coatora, ao endereçamento e demais circunstâncias deve ter aplicação no pedido efetuado por petição dirigida ao juiz, de modo que não há necessidade de se retornar a essas questões. 


\section{CONCLUSÃO}

Uma vez vencida a etapa de estudo e apontamento dos diversos aspectos do trancamento do inquérito policial e da utilização do habeas corpus e da petição dirigida ao juiz competente para praticar atos no inquérito, instrumentos adequados para esse fim, é possível apontar os principais pontos obtidos como resultado desse estudo em tópicos resumidos, onde se apresentarão as conclusões parciais e tomada de posição pessoal apresentada no desenvolvimento do texto.

Seguiu-se o caminho proposto, ou seja, houve inicialmente a análise dos principais aspectos do inquérito policial, essencial para que fosse possível estudar e compreender as hipóteses de seu trancamento, bem como as características fundamentais do habeas corpus, tanto processuais como históricas, aplicáveis ao pedido formulado ao juiz competente por simples petição.

É possível, assim, apontar os resultados obtidos, nos seguintes termos:

1. O trancamento do inquérito policial é a interrupção da investigação já instaurada para apurar o autor do fato e a materialidade do suposto delito quando lhe faltar justa causa.

2. O inquérito policial surgiu no Brasil com a Lei n. 2.033, de 24-9-1871, regulamentada pelo Decreto-lei n. 4.824, de 22-11-1871.

3. O inquérito policial é um conjunto de atos de natureza investigatória, informativa, instaurado para a apuração das infrações penais e da sua autoria, sob a responsabilidade da polícia judiciária.

4. O objeto do inquérito policial é a notícia-crime dando conta da existência da autoria e da materialidade. 
5. A finalidade do inquérito policial é servir de instrumento para a propositura da ação penal pelo Ministério Público, nos casos de ação penal pública, ou ao ofendido ou quem tenha qualidade para representá-lo, nas hipóteses de ação penal privada.

6. O inquérito policial serve para demonstrar ao juiz a presença ou não da justa causa para o recebimento ou rejeição da denúncia ou da queixa.

7. A autoridade policial deve atuar, em princípio, dentro do território de sua respectiva circunscrição, mas poderá ordenar diligências em circunscrição de outra, independentemente de precatórias ou requisições, desde que isso seja necessário para o cumprimento de suas funções.

8. O Ministério Público pode realizar investigações de crimes de ação penal pública incondicionada.

9. As comissões parlamentares de inquérito podem realizar investigações para a apuração de fato determinado e por prazo certo, sendo suas conclusões, se o caso, encaminhadas ao Ministério Público, para que promova a responsabilidade civil ou criminal dos infratores.

10. O indiciamento é um ato formal realizado pela autoridade policial e consiste em imputar ao suspeito seu envolvimento com a infração penal investigada.

11. Nos crimes de ação penal pública incondicionada, o inquérito policial terá início de ofício, quando a autoridade policial tomar conhecimento diretamente da ocorrência do crime, mediante requisição da autoridade judiciária ou do Ministério Público e mediante requerimento do ofendido ou de quem tiver qualidade para representá-lo (art. 5o, I e II do Código de Processo Penal).

12. A autoridade policial pode indeferir requerimento do ofendido ou de quem tiver qualidade para representá-lo para a abertura de inquérito policial nos crimes de ação penal pública incondicionada, mas não pode indeferir requisição da autoridade judiciária ou do Ministério Público, eis que o requerimento representa pedido, ao passo que a requisição representa ordem. 
13. Nos crimes de ação penal pública condicionada, o inquérito policial só terá início com a representação do ofendido ou de quem tiver qualidade para representá-lo, bem como por requisição do Ministro da Justiça nos crimes contra a honra praticados contra o Presidente da República ou chefe de governo estrangeiro.

14. Nos crimes de ação penal privada, a autoridade policial somente poderá iniciar o inquérito quando houver requerimento de quem tenha qualidade para intentá-la, ou seja, o ofendido ou quem tenha qualidade para representá-lo.

15. O inquérito policial deve ser concluído no prazo de 10 dias, se o indicado estiver preso, e de 30 dias, se solto, quando a apuração for de competência das polícias civis. Quando a apuração for de competência da polícia federal, estando o indiciado preso, o prazo é de 15 dias, renováveis por mais 15 . Há outros prazos de conclusão em leis especiais.

16. O relatório elaborado pela autoridade policial é a última peça do inquérito policial e nele constarão as diligências realizadas para a apuração do fato delituoso, devendo ser remetido ao juízo competente com os instrumentos do crime e os objetos que interessarem à prova.

17. A autoridade policial não pode arquivar autos de inquérito policial.

18. A decisão que determina o arquivamento de inquérito policial não comporta recurso.

19. Não se admite o arquivamento implícito do inquérito policial, cabendo ao juiz que receber a denúncia exercer o controle previsto no art. 28 do Código de Processo Penal.

20. A decisão que determina o arquivamento do inquérito policial não faz coisa julgada material, salvo em hipóteses excepcionais quando é apreciado o mérito da acusação.

21. Quando o inquérito policial for arquivado por despacho do juiz, a requerimento do Ministério Público, a ação penal não poderá ser iniciada sem novas provas. 
22. O desarquivamento depende de requerimento do Ministério Público nos crimes de ação penal pública ou do ofendido - ou de quem tenha qualidade para representá-lo - nos crimes de ação penal privada, e não pode ser determinado de ofício pelo juiz.

23. É possível o trancamento do inquérito policial quando lhe faltar justa causa.

24. O trancamento do inquérito policial é medida excepcional, só cabível se faltar justa causa para sua instauração e prosseguimento ou se presentes uma das causas que fundamentem seu encerramento.

25. A justa causa para a instauração e prosseguimento do inquérito policial pressupõe tipicidade e apuração de provável ou possível autor de um crime.

26. Além do pressuposto da ausência da justa causa há as causas ou hipóteses que fundamentam o trancamento do inquérito policial.

27. A apuração de fato inexistente, a atipicidade da conduta ou quando for evidente que o investigado não seja seu autor, o crime impossível e o crime putativo são causas que podem fundamentar o trancamento do inquérito policial..

28. A inexistência de representação nos crimes de ação penal pública condicionada, a inexistência de requerimento do ofendido ou de seu representante para a instauração do inquérito policial nos crimes de ação penal privada, a decadência, a renúncia e a prescrição são causas que justificam o trancamento do inquérito policial.

29. As causas legais de exclusão da antijuridicidade previstas no artigo 23 do Código Penal, ou seja, estado de necessidade, legítima defesa, o estrito cumprimento do dever legal e o exercício regular do direito, assim como as causas previstas na Parte Especial do Código Penal, sem prejuízo das causas supralegais de exclusão da antijuridicidade servem de fundamento para o trancamento do inquérito policial.

30. A embriaguez fortuita completa, o erro sobre a ilicitude do fato inevitável, o erro sobre situação de fato que se existisse tornaria a ação legítima quando não derivar de culpa, a coação moral irresistível, a obediência hierárquica a ordem não manifestamente ilegal, 
como causas legais de exclusão de culpabilidade, assim como a causa supralegal de exclusão de culpabilidade pela inexigibilidade de conduta diversa podem fundamentar o trancamento do inquérito policial.

31. A morte do agente, a anistia própria, a abolitio criminis, a prescrição da pretensão punitiva, a ausência de representação nos crimes de ação penal pública condicionada, a ausência de requerimento do ofendido ou de seu representante para o início do inquérito nas hipóteses de ação penal privada, a decadência, a renúncia ao direito de queixa, a retratação do agente nos crimes de calúnia, difamação, falsa perícia ou falso testemunho, o cumprimento da pena no estrangeiro ou o ressarcimento do dano no peculato culposo, como causas de extinção da punibilidade podem ser invocadas para o trancamento do inquérito policial.

32. É causa de trancamento do inquérito policial a obtenção de provas por meios ilícitos.

33. O princípio da insignificância é causa legítima para o trancamento do inquérito policial, inclusive de ofício pela autoridade judiciária ao receber os respectivos autos.

34. É causa de trancamento do inquérito policial a injustificada demora na conclusão dos trabalhos policiais quando o crime for de simples elucidação, com fundamento no princípio da duração razoável do processo (art. 5, LXXVIII da Constituição Federal), aplicável no âmbito administrativo.

35. A natureza jurídica da decisão judicial que acolhe o pedido de trancamento do inquérito policial é a de sentença, uma vez que põe fim à investigação e impede o posterior desarquivamento do inquérito policial, ainda que surjam novas provas.

36. A decisão de trancamento do inquérito policial é judicial, visto que analisa o mérito, de modo que faz coisa julgada material.

37. A sentença de trancamento do inquérito policial deve ser precedida de manifestação do Ministério Público, seja em crime de ação penal pública ou privada. 
38. A sentença que decide pelo trancamento do inquérito policial deve ser fundamentada, sob pena de nulidade.

39. O projeto de lei n. 156 de 2009 em trâmite no Senado Federal prevê a criação do juiz de garantias que será o responsável pela apreciação do pedido de trancamento do inquérito policial em primeiro grau de jurisdição.

40. O habeas corpus é um dos instrumentos adequados para ser requerido o trancamento do inquérito policial com fundamento no art. 648, I, do Código de Processo Penal.

41. É possível o trancamento do inquérito policial por meio de ordem expedida de ofício pelo juiz, na forma do art. $654, \S 2^{\circ}$ do Código de Processo Penal.

42. Quando o inquérito policial tiver início de ofício, por conhecimento próprio da autoridade policial, ou quando esta atende a requerimento do ofendido ou acolhe informação de ocorrência de crime por qualquer do povo, ela será a autoridade coatora e a competência para o processamento e julgamento de habeas corpus para o trancamento de inquérito policial será do juiz de primeiro grau.

43. Quando o inquérito policial tiver início por requisição da autoridade judiciária ou do Ministério Público, estas serão consideradas autoridades coatoras e a competência para o processamento e julgamento do habeas corpus impetrado para o trancamento do inquérito será do tribunal responsável pelo julgamento de eventuais atos praticados por tais autoridades, ou seja, Tribunal de Justiça para juízes de direito ou promotores de justiça ou Tribunal Regional Federal para juízes federais ou procuradores da República.

44. Em caso de denegação da ordem, é possível a renovação do pedido de trancamento de inquérito policial em habeas corpus se o fundamento for diverso do anterior.

45. Contra as sentenças proferidas em habeas corpus em primeiro grau de jurisdição cabe recurso em sentido estrito (art. 581, X do Código de Processo Penal), seja ela concessiva ou denegatória da ordem pleiteada. 
46. Contra as decisões proferidas em habeas corpus em única instância pelos Tribunais Superiores cabe o recurso ordinário dirigido ao Supremo Tribunal Federal, quando denegada a ordem (art. 102, II, a, da Constituição Federal), ou ao Superior Tribunal de Justiça, quando a decisão for proferida em única ou última instância pelos Tribunais Regionais Federais ou pelos Tribunais dos Estados e do Distrito Federal (art. 105, II, $a$, da Constituição Federal), também quando denegatória a decisão Em caso de concessão da ordem, é cabível o recurso extraordinário dirigido ao Supremo Tribunal Federal (art. 102, III da Constituição Federal) e o recurso especial dirigido ao Superior Tribunal de Justiça (art. 105, III da Constituição Federal), desde que atendidos os demais requisitos constitucionais..

47. O recurso de ofício previsto no art. 574, I do Código de Processo Penal não foi recepcionado pela Constituição Federal de 1988, visto que acolheu o sistema acusatório e o princípio da imparcialidade do julgador.

48. A petição dirigida ao juiz competente para praticar atos no inquérito policial é outro instrumento adequado para o trancamento do inquérito policial, sendo-lhe aplicáveis os mesmos requisitos previstos para o habeas corpus. 


\section{BIBLIOGRAFIA}

ARANHA, Adalberto José Q. T. de Camargo. Dos recursos no processo penal. $3^{\mathrm{a}}$ ed. rev. atual. São Paulo: Saraiva, 2010.

ARAÚJO, Vivaldo Jorge de; SIQUEIRA, Geraldo Batista de. Do trancamento da ação penal subsidiária. Revista Brasileira de Direito Processual. Uberaba: Vitória Artes Gráficas; Rio de Janeiro: Forense; Belo Horizonte: Fórum, ano V, v. 19, p. 107-114, jul./set. 1979.

AVOLIO, Luiz Francisco Torquato. Provas ilícitas: interceptações telefônicas, ambientais e gravações clandestinas. $3^{\text {a }}$ ed. rev. amp. atual. São Paulo: Revista dos Tribunais, 2003.

BADARÓ, Gustavo Henrique; LOPES JUNIOR, Aury. Direito ao processo penal no prazo razoável. $2^{a}$ ed. rev. atual. Rio de Janeiro: Lumen Juris, 2009.

BARBOSA, Manoel Messias. Inquérito policial. $7^{\text {a }}$ ed. rev. atual. São Paulo: Método, 2009.

BATISTA, Weber Martins. Trancamento de inquérito policial. Revista Forense. Rio de Janeiro: Forense, ano 90, no 328, p. 101-104, out./dez. 1994.

BECCARIA, Cesare. Dos delitos e das penas. $2^{\text {a }}$ ed. rev. Trad. Lucia Guidicini e Alessandro Berti Contessa. São Paulo: Martins Fontes, 2000.

BEDÊ JUNIOR, Américo; SENNA, Gustavo. Princípios do processo penal: entre o garantismo e a efetividade da sanção. São Paulo: Revista dos Tribunais, 2009.

BORGES DA ROSA, Inocêncio. Comentários ao código de processo penal. $3^{\mathrm{a}}$ ed. São Paulo: Revista dos Tribunais, 1982. 
BUENO, Francisco da Silveira. Minidicionário da língua portuguesa. São Paulo: FTD, 1996.

CAPEZ, Fernando. Curso de processo penal. $18^{\mathrm{a}}$ ed. São Paulo: Saraiva, 2011.

CARNELUTTI, Francesco. As misérias do processo penal. 2a ed. Leme: Edijur, 2010.

CARVALHO, Salo de. Considerações sobre o arquivamento do inquérito policial: requisitos e controle judicial (estudo de caso). Revista Brasileira de Ciências Criminais. São Paulo: Revista dos Tribunais, ano 18, nº 83, p. 322-349, mar./abr. 2010.

CARVALHO, Djalma Eutímio de. Curso de processo penal. $2^{\mathrm{a}}$ ed. rev. atual. Rio de Janeiro: Forense, 2009.

CHIAVARIO, Mario. Diritto processuale penale. Quarta edizione. Torino: Utet Giuridica, 2009.

. Os direitos do acusado e da vítima. In: DELMAS-MARTY, Mireille (org.). Processos penais da Europa. Trad. Fauzi Hassan Choukr, com a colaboração de Ana Claudia Ferigato Choukr. Rio de Janeiro: Lumen Juris, p. 563-619, 2005.

CHOUKR, Fauzi Hassan. Garantias constitucionais na investigação criminal. $3^{\mathrm{a}}$ ed. rev. amp. atual. Rio de Janeiro: Lumen Juris, 2006.

CONSTANTINO, Lúcio Santoro de. Recursos criminais, sucedâneos recursais criminais e ações impugnativas autônomas criminais. $4^{\mathrm{a}}$ ed. rev. amp. atual. Porto Alegre: Livraria do Advogado, 2010.

COUTINHO, Jacinto Nelson de Miranda. A natureza cautelar da decisão de arquivamento do inquérito policial. Revista de Processo. São Paulo: Revista dos Tribunais, ano $18, \mathrm{n}^{\circ}$ 70, p. 49-58, abr./jun. 1993. 
DERVIEUX, Valérie. O sistema francês. In: DELMAS-MARTY, Mireille (org.). Processos penais da Europa. Trad. Fauzi Hassan Choukr, com a colaboração de Ana Claudia Ferigato Choukr. Rio de Janeiro: Lumen Juris, p. 151-242, 2005.

DEZEM, Guilherme Madeira. Prática penal. In: MACHADO, Ângela C. Cangiano; DEZEM, Guilherme Madeira; JUNQUEIRA, Gustavo Octaviano Diniz et al. Coleção prática forense. $6^{\mathrm{a}}$ ed. rev. atual. São Paulo: Revista dos Tribunais, 2009, v. 6.

Da prova penal: tipo processual, provas típicas e atípicas. Campinas: Conceito - Millennium, 2008.

FELDENS, Luciano; SCHMIDT, Andrei Zenkner. Investigação criminal e ação penal. $2^{\text {a }}$ ed. rev. amp. atual. Porto Alegre: Livraria do Advogado, 2007.

FERNANDES, Antonio Scarance. Reação defensiva à imputação. São Paulo: Revista dos Tribunais, 2002.

. Reflexões sobre as noções de eficiência e de garantismo no processo penal. In: FERNANDES, Antonio Scarance; ALMEIDA, José Raul Gavião de; MORAES, Maurício Zanoide de (coord.). Sigilo no processo penal: eficiência e garantismo. São Paulo: Revista dos Tribunais, p. 9-28, 2008.

- O equilíbrio na repressão ao crime organizado. In: FERNANDES, Antonio Scarance; ALMEIDA, José Raul Gavião de; MORAES, Maurício Zanoide de (coord.). Crime organizado: aspectos processuais. São Paulo: Revista dos Tribunais, p. 9-28, 2009a.

. O equilíbrio entre a eficiência e o garantismo e o crime organizado. In: TOLEDO, Otávio Augusto de Almeida; LANFREDI, Luís Geraldo Sant'Ana; SOUZA, Luciano Anderson de et al. (coord.). Repressão penal e crime organizado: os novos rumos da política criminal após o 11 de setembro. São Paulo: Quartier Latin, p. 225-266, 2009b.

Processo penal constitucional. $6^{\text {a }}$ ed. rev. amp. atual. São Paulo: Revista dos Tribunais, 2010. 
FERRAJOLI, Luigi. Direito e razão: teoria do garantismo penal. $3^{\mathrm{a}} \mathrm{ed}$. rev. Trad. Ana Paula Sica, Fauzi Hassan Choukr, Juarez Tavares et al. São Paulo: Revista dos Tribunais, 2010 .

FERREIRA, Aurélio Buarque de Holanda. Dicionário Aurélio da língua portuguesa. $5^{\mathrm{a}}$ ed. Curitiba: Positivo, 2010.

FERREIRA, Pinto. Teoria e prática do habeas corpus. $4^{\mathrm{a}}$ ed. São Paulo: Saraiva, 1988.

FRAGOSO, Heleno Cláudio. Lições de direito penal. $15^{\mathrm{a}}$ ed. rev. atual. Rio de Janeiro: Forense, 1994.

GARCIA, Basileu. Instituições de direito penal. $4^{\text {a }}$ ed. São Paulo: Max Limonad, 1978, v. I, tomo I.

Instituições de direito penal. In: Série clássicos jurídicos. $7^{\mathrm{a}}$ ed. rev. atual. São Paulo: Saraiva - Fundação Getúlio Vargas, 2008, v. I, tomo II.

GIACOMOLLI, Nereu José. A fase preliminar do processo penal: crises, misérias e novas metodologias investigatórias. Rio de Janeiro: Lumen Juris, 2011.

GOMES, Luiz Flávio. Comentários à convenção americana sobre direitos humanos. In: GOMES, Luiz Flávio; MAZZUOLI, Valerio de Oliveira. Coleção ciências criminais. $2^{\text {a }}$ ed. rev. amp. atual. São Paulo: Revista dos Tribunais, 2009, v. 4.

GOMES FILHO, Antonio Magalhães. Direito à prova no processo penal. São Paulo: Revista dos Tribunais, 1997.

GRECO FILHO, Vicente. Interceptação telefônica. São Paulo: Saraiva, 1996.

Manual de processo penal. $8^{\mathrm{a}}$ ed. rev. amp. atual. São Paulo: Saraiva, 2010. 
GRINOVER, Ada Pellegrini; GOMES FILHO, Antonio Magalhães; FERNANDES, Antonio Scarance. As nulidades no processo penal. 12 a ed. rev. atual. São Paulo: Revista dos Tribunais, 2011a.

GRINOVER, Ada Pellegrini; GOMES FILHO, Antonio Magalhães; FERNANDES, Antonio Scarance. Recursos no processo penal. $7^{\text {a }}$ ed. rev. atual. São Paulo: Revista dos Tribunais, $2011 \mathrm{~b}$.

GROSNER, Marina Quezado. A seletividade do sistema penal na jurisprudência do Superior Tribunal de Justiça: o trancamento da criminalização secundária por decisões em habeas corpus. São Paulo: Instituto Brasileiro de Ciências Criminais, 2008.

GUIMARÃES, Aureliano. O habeas corpus: doutrina, prática e jurisprudência. São Paulo: Saraiva, 1925.

JARDIM, Afrânio Silva. Arquivamento e desarquivamento do inquérito policial. Revista de Processo. São Paulo: Revista dos Tribunais, ano IX, no 35, p. 264-276, abr./jun. 1984.

JESUS, Damásio Evangelista de. Direito penal: parte geral. 32 ed. rev. atual. São Paulo: Saraiva, 2011, v. 1.

. Prescrição penal. 19a ed. São Paulo: Saraiva, 2010.

JUY-BIRMANN, Rudolphe. O sistema alemão. In: DELMAS-MARTY, Mireille (org.). Processos penais da Europa. Trad. Fauzi Hassan Choukr, com a colaboração de Ana Claudia Ferigato Choukr. Rio de Janeiro: Lumen Juris, p. 5-73, 2005.

LIMA, Marcellus Polastri. Manual de processo penal. 5 ed. Rio de Janeiro: Lumen Juris, 2010.

LOPES JUNIOR, Aury. A (de) mora jurisdicional e o direito de ser julgado em um prazo razoável no processo penal. Boletim do Instituto Brasileiro de Ciências Criminais. São Paulo: Instituto Brasileiro de Ciências Criminais, ano 13, nº 152, p. 4-5, jul. 2005. 
A (in) existência de poder geral de cautela no processo penal. Boletim do Instituto Brasileiro de Ciências Criminais. São Paulo: Instituto Brasileiro de Ciências Criminais, ano $17, \mathrm{n}^{\circ} 203$, p. 8-9, out. 2009.

. Direito ao processo penal no prazo razoável. Revista Brasileira de Ciências Criminais. São Paulo: Revista dos Tribunais, v. 65, p. 209-250, mar./abr. 2007.

Direito processual penal e sua conformidade constitucional. $4^{\mathrm{a}} \mathrm{ed}$. rev. atual.

Rio de Janeiro: Lumen Juris, 2009.

. Sistemas de investigação preliminar no processo penal. $2^{\mathrm{a}}$ ed. Rio de Janeiro: Editora Lumen Juris, 2003.

MACHADO, Antônio Alberto. Curso de processo penal. $3^{a}$ ed. aum. atual. São Paulo: Atlas, 2010.

MARQUES, José Frederico. Elementos de direito processual penal. Rio de Janeiro: Forense, 1965, v. 4.

. Tratado de direito penal: da infração penal. Campinas: Millennium, 2002, v.

II.

. Tratado de direito penal: propedêutica penal e norma penal. $1^{\mathrm{a}}$ ed. atual. Campinas: Bookseller, 1997, v. I.

. Tratado de direito processual penal. São Paulo: Saraiva, 1980, v. 2.

MAYA, André Machado. Imparcialidade e processo penal: da prevenção da competência ao juiz de garantias. Rio de Janeiro: Lumen Juris, 2011.

MENDRONI, Marcelo Batlouni. Crime organizado: aspectos gerais e mecanismos legais. $3^{\text {a }}$ ed. São Paulo: Atlas, 2009. 
MIRABETE, Julio Fabbrini; FABBRINI, Renato N. Manual de direito penal: parte geral. 26a ed. rev. atual. São Paulo: Atlas, 2010, v. 1.

_. Processo penal. $7^{\text {a }}$ ed. rev. atual. São Paulo: Atlas, 1997.

MIRANDA, Pontes de. História e prática do habeas corpus. Atualizado por Vilson Rodrigues Alves. $3^{\mathrm{a}}$ ed. Campinas: Bookseller, 2007, v. 2.

MOSSIN, Heráclito Antônio. Curso de processo penal. 2ª ed. São Paulo: Atlas, 1998, v.1.

MOURA, Maria Thereza Rocha de Assis. Justa causa para a ação penal: doutrina e jurisprudência. In: Coleção de Estudos de Processo Penal Prof. Joaquim Canuto Mendes de Almeida. São Paulo: Revista dos Tribunais, 2001, v. 5.

NOGUEIRA, Paulo Lúcio. Curso completo de processo penal. $7^{\mathrm{a}}$ ed. rev. amp. atual. São Paulo: Saraiva, 1993.

NORONHA, E. Magalhães. Curso de direito processual penal. $19^{\text {a }}$ ed. São Paulo: Saraiva, 1989.

. Direito penal. Atualizado por Adalberto José Q. T. de Camargo Aranha. $31^{\mathrm{a}}$ ed. São Paulo: Saraiva, 1995, v. 1.

NUCCI, Guilherme de Souza. Manual de processo penal e execução penal. $5^{\mathrm{a}}$ ed. rev. amp. atual. São Paulo: Revista dos Tribunais, 2008.

. Provas no processo penal. São Paulo: Revista dos Tribunais, 2009.

NUNES, Rizzatto. Manual da monografia jurídica: como se faz: uma monografia, uma dissertação, uma tese. $8^{\mathrm{a}}$ ed. rev. São Paulo: Saraiva, 2011.

PARIZ, Ângelo Aurélio Gonçalves. O princípio do devido processo legal: direito fundamental do cidadão. Coimbra: Almedina, 2009. 
PASSOS, Paulo Roberto da Silva. Do “habeas corpus”: coação ilegal. São Paulo: Edipro, 1991.

PERRODET, Antoinette. O sistema italiano. In: DELMAS-MARTY, Mireille (org.). Processos penais da Europa. Trad. Fauzi Hassan Choukr, com a colaboração de Ana Claudia Ferigato Choukr. Rio de Janeiro: Lumen Juris, p. 343-429, 2005.

PESQUIÉ, Brigitte. O sistema belga. In: DELMAS-MARTY, Mireille (org.). Processos penais da Europa. Trad. Fauzi Hassan Choukr, com a colaboração de Ana Claudia Ferigato Choukr. Rio de Janeiro: Lumen Juris, p. 77-148, 2005.

PINHEIRO, Ricardo Henrique Araújo. O trancamento do inquérito policial ocasionado pela injustificada demora na conclusão dos trabalhos policiais: Análise feita à luz do princípio da razoabilidade. São Paulo: Instituto Brasileiro de Ciências Criminais, dez. 2009. Disponível em: <http://www.ibccrim.org.br/site/artigos>. Acesso em: 4-7-2012.

PITOMBO, Sérgio Marcos de Moraes. Arquivamento do inquérito policial: sua força e efeito. Revista do Advogado. São Paulo: Associação dos Advogados de São Paulo, ano III, $n^{\circ} 11$, p. 9-15, out./dez. 1982.

PRADO, Luiz Regis. Curso de direito penal brasileiro. $9^{\text {a }}$ ed. rev. amp. atual. São Paulo: Revista dos Tribunais, 2010, v. 1.

RAMOS, João Gualberto Garcez. Curso de processo penal norte-americano. São Paulo: Revista dos Tribunais, 2006.

RANGEL, Paulo. Direito processual penal. $17^{\mathrm{a}}$ ed. rev. amp. atual. Rio de Janeiro: Lumen Juris, 2010.

ROXIN, Claus. Política criminal y sistema del derecho penal. Trad. Francisco Muñoz Conde. Barcelona: Bosch, 1972. 
SAAD, Marta. O direito de defesa no inquérito policial. In: Coleção Estudos de Processo Penal Prof. Joaquim Canuto Mendes de Almeida São Paulo: Revista dos Tribunais, 2004, v. 9.

SALLES JUNIOR, Romeu de Almeida. Inquérito policial. 3ª ed. Curitiba: Juruá, 2010.

SANTOS, Leandro Galluzzi dos. Procedimentos. In: MOURA, Maria Thereza Rocha de Assis (coord.). As reformas no processo penal. São Paulo: Revista dos Tribunais, 2004.

SILVA, Luiz Cláudio; SILVA, Franklyn Roger Alves. Manual de processo e prática penal. $4^{\text {a }}$ ed. rev. amp. atual. Rio de Janeiro: Forense, 2010.

SILVA JÚNIOR, Délio Lins e. O trancamento do inquérito policial pela falta de razoabilidade no prazo de sua duração. Boletim do Instituto Brasileiro de Ciências Criminais. São Paulo: Instituto Brasileiro de Ciências Criminais, ano 13, no 160, p. 4-5, mar. 2006.

SIQUEIRA, Geraldo Batista de. Inquérito policial - requisição judicial. Revista Jurídica do Rio Grande do Sul. Porto Alegre: Síntese - Notadez, ano XXXVII, no 147, p. 42-45, jan. 1990.

O habeas corpus tranca o processo? In: GARCIA, Maria; PIOVESAN, Flávia (org.). Direitos humanos: instrumentos e garantias de proteção: garantias constitucionais, garantias jurisdicionais e aspectos gerais. Coleção Doutrinas Essenciais. São Paulo: Revista dos Tribunais, p. 311-317, 2011, v. 5.

SOARES, Fábio Aguiar Munhoz. Prova ilícita no processo. Curitiba: Juruá, 2009.

SOUZA, José Barcelos de. Habeas-corpus processual. Boletim do Instituto Brasileiro de Ciências Criminais. São Paulo: Instituto Brasileiro de Ciências Criminais, ano 4, no 50, p. 3, jan. 1997. 
SPENCER, J. R. O sistema inglês. In: DELMAS-MARTY, Mireille (org.). Processos penais da Europa. Trad. Fauzi Hassan Choukr, com a colaboração de Ana Claudia Ferigato Choukr. Rio de Janeiro: Lumen Juris, p. 245-339, 2005.

STOCO, Rui. Princípio da insignificância nos crimes contra a ordem tributária. In: SUANNES, Adauto; TORON, Alberto Zacharias; BIANCHINI, Alice et al. (colab.). Escritos em homenagem a Alberto Silva Franco. São Paulo: Revista dos Tribunais, p. 370-386, 2003.

TEOTÔNIO, Paulo José Freire; MARTINS, Carlos Renato Sampaio. O perdão judicial e o arquivamento do inquérito policial. Revista Síntese de Direito Penal e Processo Penal. Porto Alegre: Síntese, ano IV, no 25, p. 34-40, abr./maio 2004.

TOLEDO, Francisco de Assis. Princípios básicos de direito penal. $3^{\mathrm{a}}$ ed. São Paulo: Saraiva, 1987.

TORNAGHI, Hélio. Curso de processo penal. 5a ed. São Paulo: Saraiva, 1988. v 2.

TOURINHO FILHO, Fernando da Costa. Manual de processo penal. $14^{\mathrm{a}}$ ed. São Paulo: Saraiva, 2011a.

. Processo penal. $33^{\mathrm{a}}$ ed. rev. atual. São Paulo: Saraiva, 2011 b, v. 1.

TUCCI, Rogério Lauria. Direitos e garantias individuais no processo penal brasileiro. $3^{\text {a }}$ ed. rev. amp. atual. São Paulo: Revista dos Tribunais, 2009.

. Investigação criminal no projeto de reforma do código de processo penal. Revista do Advogado. São Paulo: Associação dos Advogados de São Paulo, ano XXIV, nº 78, p. 103-110, set. 2004.

. Ministério público e investigação criminal. São Paulo: Revista dos Tribunais, 2004. 
. Pedido de arquivamento de inquérito policial e preclusão consumativa. Revista dos Tribunais. São Paulo: Revista dos Tribunais, ano 94, no 831, p. 507-516, jan. 2005.

VICO MAÑAS, Carlos. O princípio da insignificância como excludente da tipicidade no direito penal. São Paulo: Saraiva, 1994.

- Princípio da insignificância: excludente da tipicidade ou da ilicitude? In: SUANNES, Adauto; TORON, Alberto Zacharias; BIANCHINI, Alice et al. (colab.). Escritos em homenagem a Alberto Silva Franco. São Paulo: Revista dos Tribunais, p. 143-150, 2003.

ZILLI, Marcos Alexandre Coelho. A iniciativa instrutória do juiz no processo penal. São Paulo: Revista dos Tribunais, 2003. 